\title{
بناء وحده تعليمية بنظام التعلم الالكتزوني (البلاك بورد) في تصميم أزياء النساء وقياس فاعليتها
}

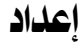

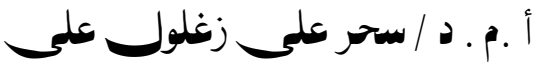 \\ الأستاذ المساعد بقسم المابلابس والنسيج ريج \\ كلية الإقتصاد المنزلي - جامعة حلوان
}

مجلة بحوث التربية النوعية ـ جامعة المنصورة

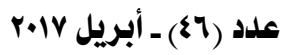


בب بناء وحلد تعليمية بنظام التعلم الاكتروني (البلاك بورد) مِ تصميم/زياء النساء وقياس فاعليتها 
مجلة بحوث التربية النوعية - علد II - أبريل r.IV

\section{بناء وحده تعليمية بنظام التعلم الالكتزوني (البلاك بورد)}

\section{في تصميسم أزياء النساء وقيساس فاعليتها}

إعداد

أ .م . .د / سحر علمزغلولعلمـــ

unill

يهدف البحث إلى بناء وحده بنظام التعله الألكتروني ( البلاك بورد ) ِِّْ تصميهم أزياء النساء

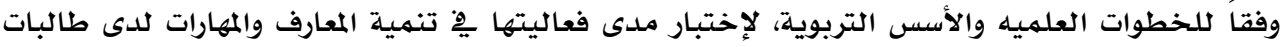

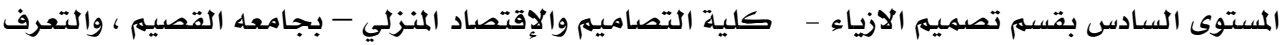
على درجة رضا الطالبات نحو إستخدام نظام البلاك بورد كوسيلة للتعلم . إقتصر البحث الحالي على المحددات التاليه:

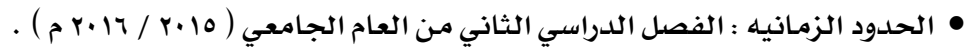

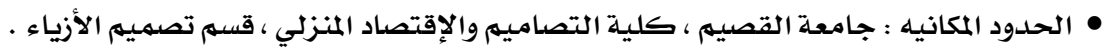

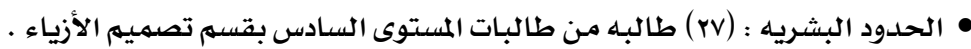

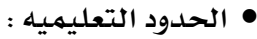

ا. وحدة من مقرر تصميم أزياء ( r ) ) والتي تدرس لطالبات المستوى السادس بقسم تصميم الأزياء

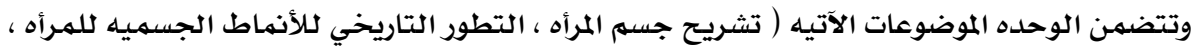

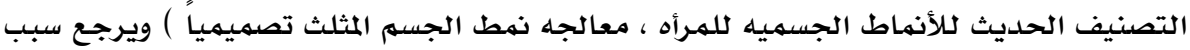

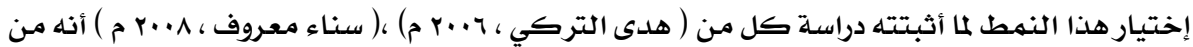

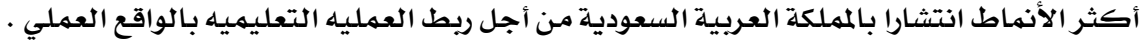

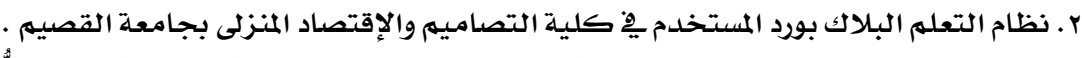

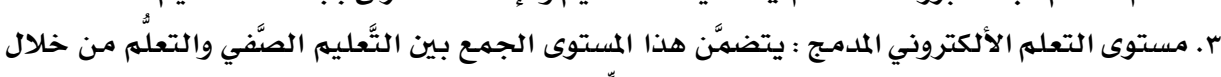

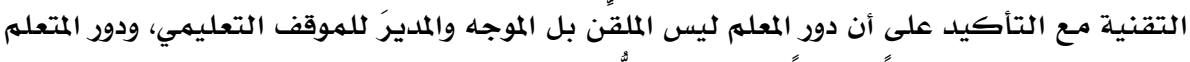
هو الأساس فهو يلعب دورا إيجابيا فى عملية تعلمهـ.

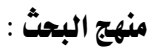
• المنهج الوصفي : من خلال تطبيق إستبيان للتعرف على درجة رضا الطالبات نحو إستخدام نظام إدارة

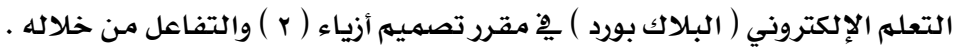


• المنهج شبه التجريبي : من خلال بناء وحلدة من مقرر تصميم أزياء ( r ) بنظام إدارة التعلم الإلكتروني

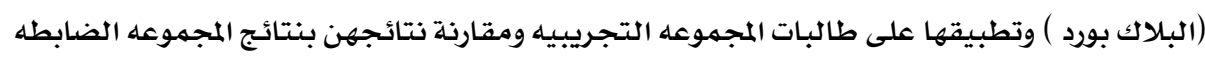

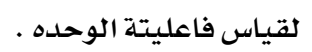
متفيرات البحث :

• المتغير المستقل : الموقع الإلكتروني التعليمي بنظام التعلم ( البلاك بورد ) لوحدة من مقرر تصميم أزياء

• المتغيرات التابعه : ( الجوانب المعرفيه ، الجوانب المهاريه ) المرتبطه بالوحدة المقترحه ، درجة قبول

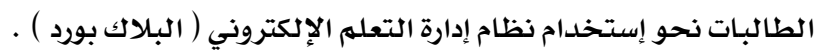

عينة البحث :

شملت عينة البحث ( rV ) طالبه من طالبات المستوى السادس " الفرقة الثالثه " بقسم تصميم

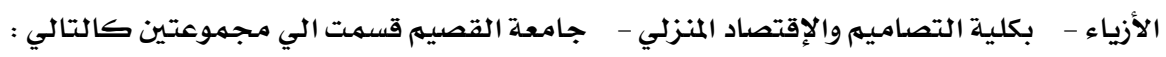

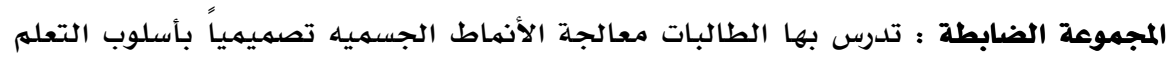

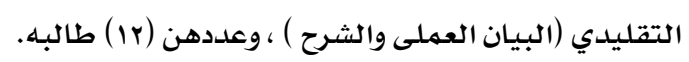

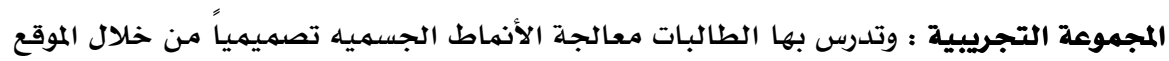

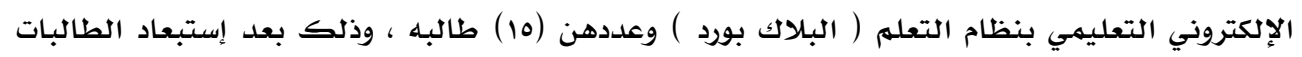

$$
\text { الباقيات دلإعاده من العام السابق. }
$$

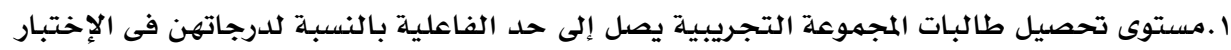

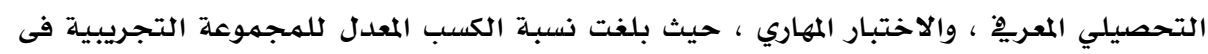

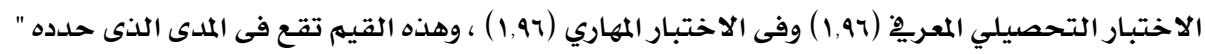

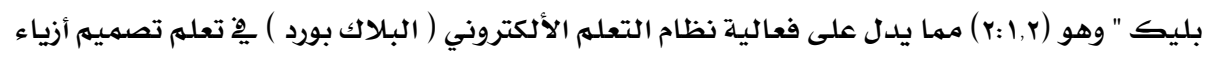
النساء.

r.وجود فروق دالة إحصائياً عند مستوى ( ا.., ) ) بين متوسطي درجات طالبات المجموعة التجريبية ِيِ

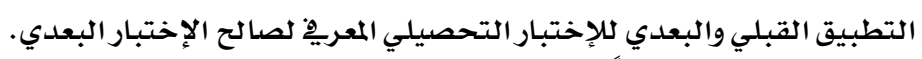

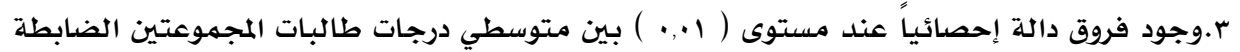

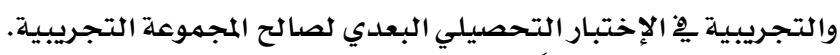

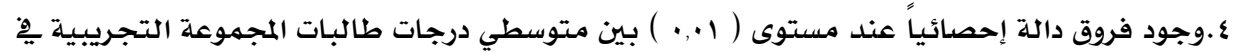

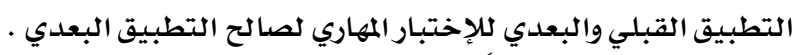

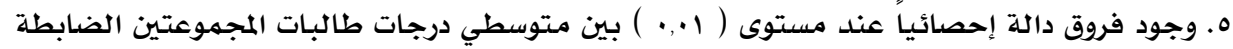

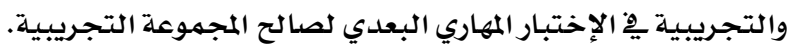

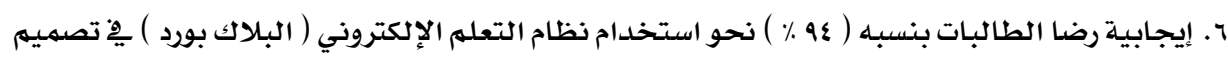

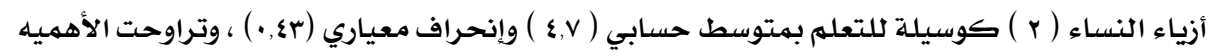

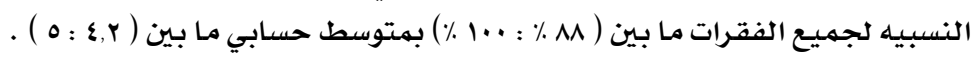




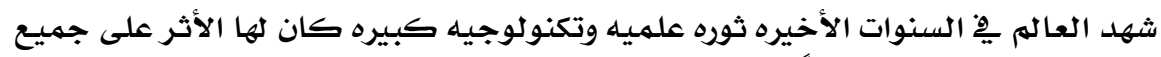

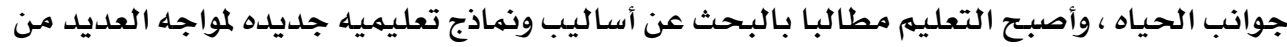

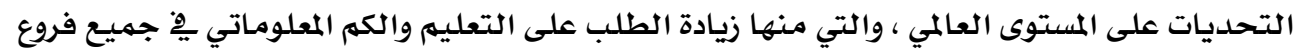

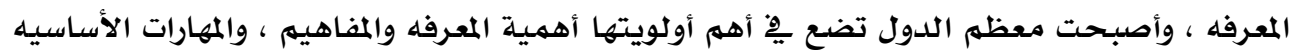

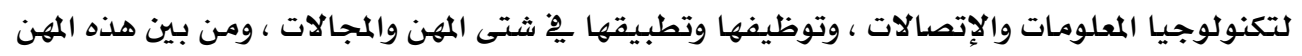

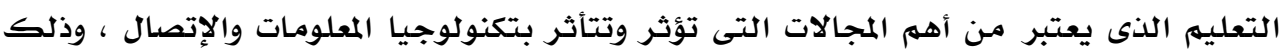

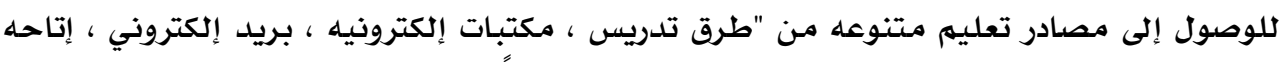

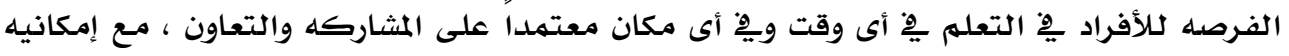

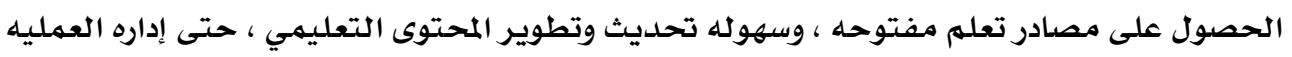

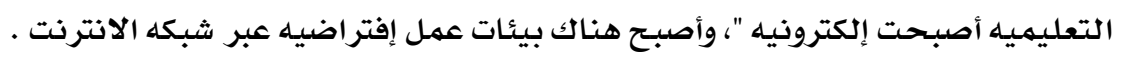

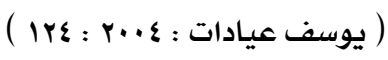

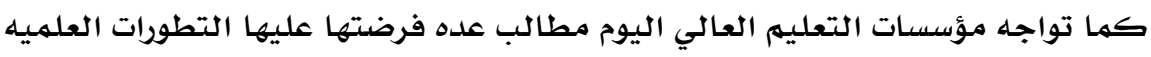
والتكنولوجيه المتلاحقه ، وأصبح عليها على الرغم من قله الإمكانيات والموارد المتاحه لها لها أن تواجها

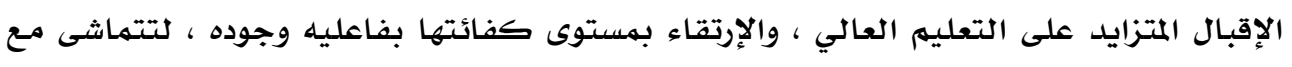

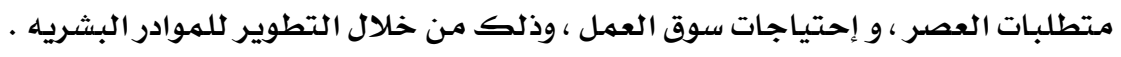
( Akkoyunlu , B\& Soylu ,M : 2016 : 46)

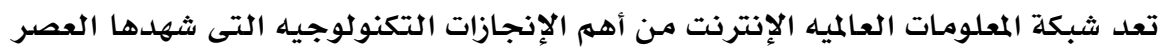

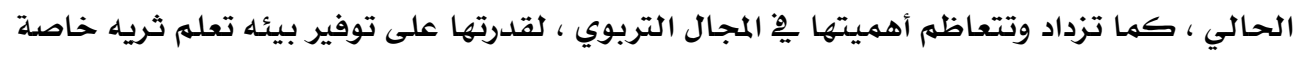

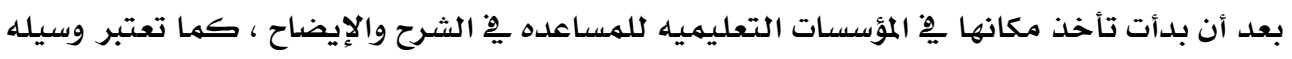

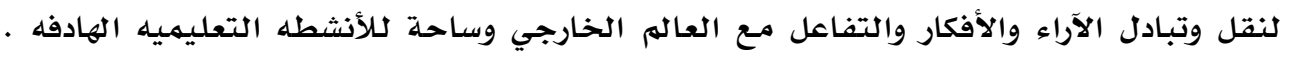

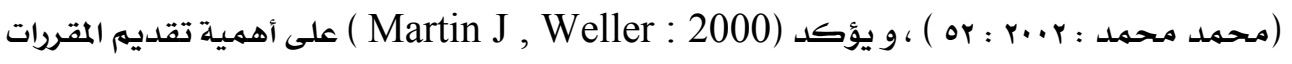

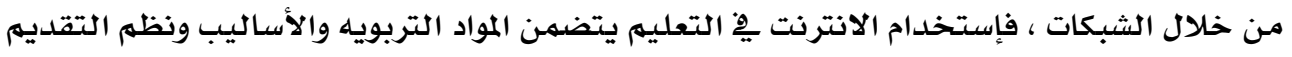

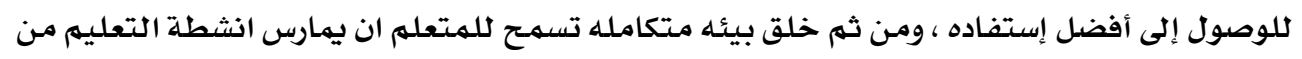

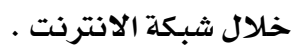

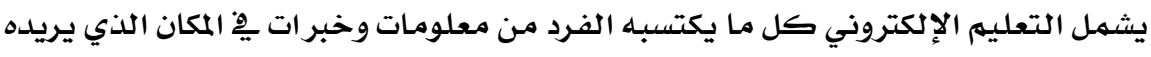

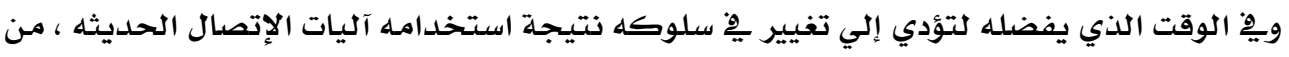

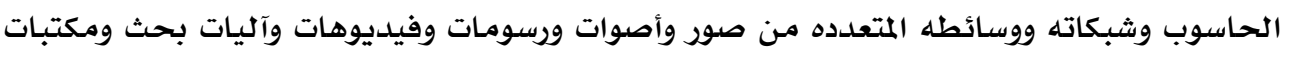

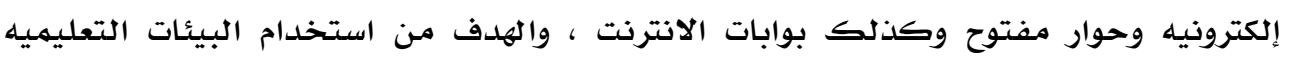

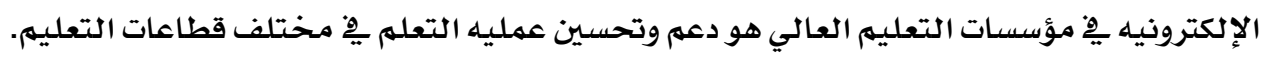

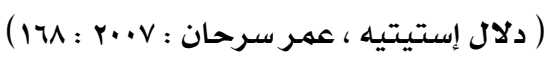


ولقد أثبتت تجارب عديده من الجامعات يّْ دول مختلفه نجاح استخدام إدارة التعليهٍ

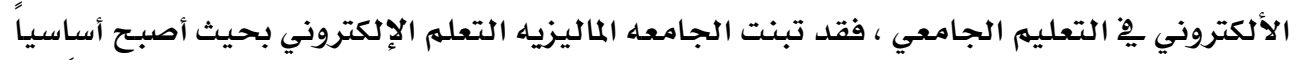

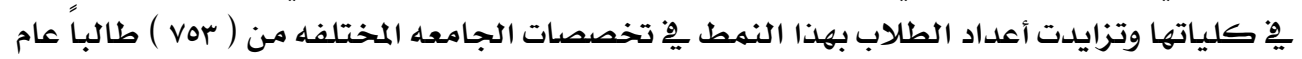

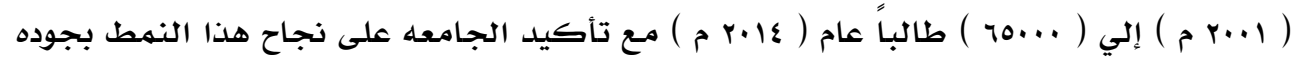

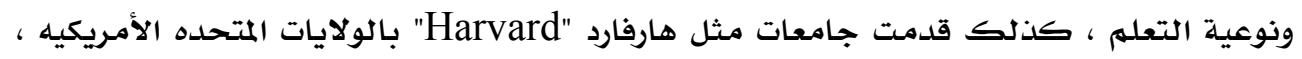

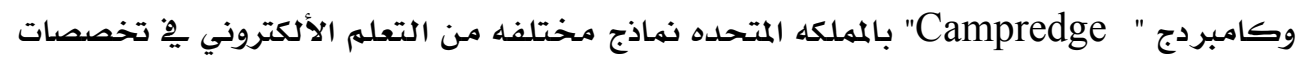

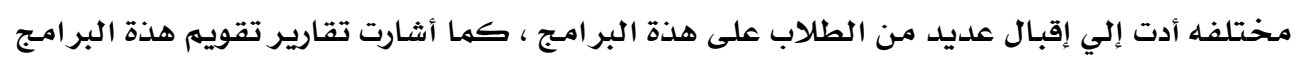

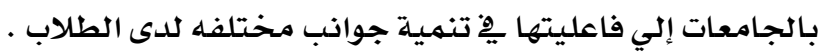

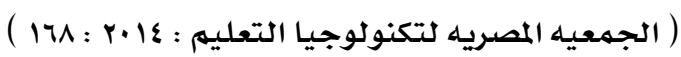

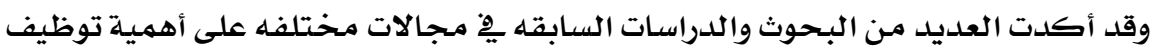

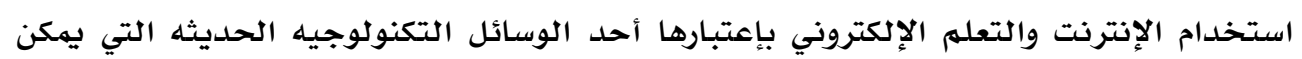

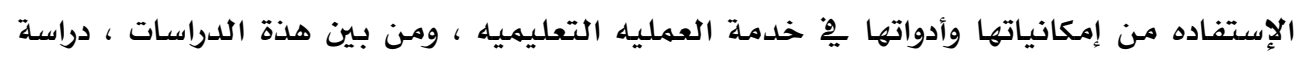
(Katherine Blair : 2000)

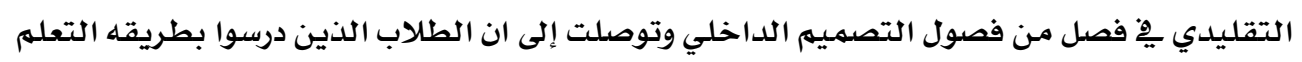

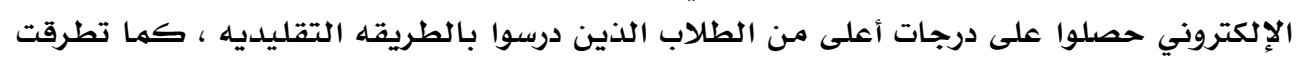

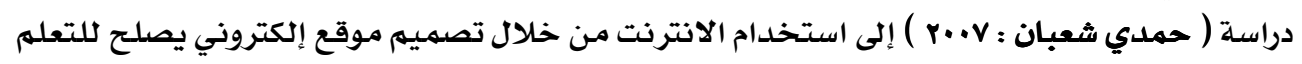

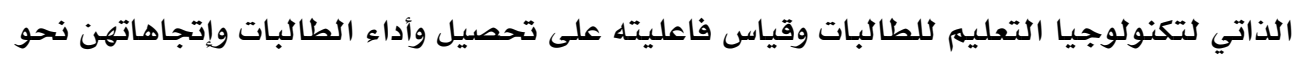

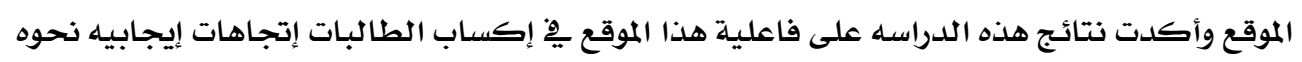

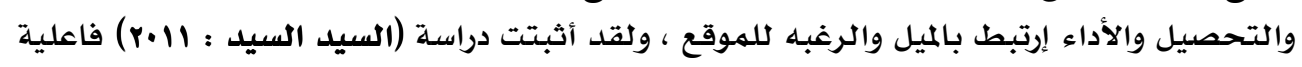

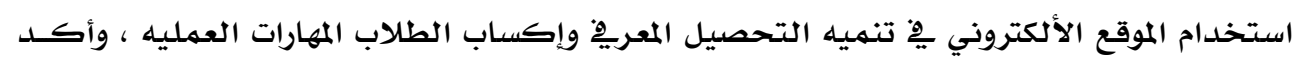

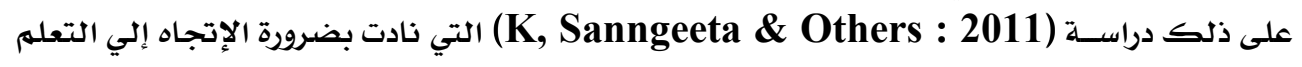

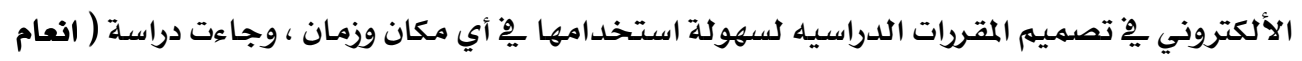

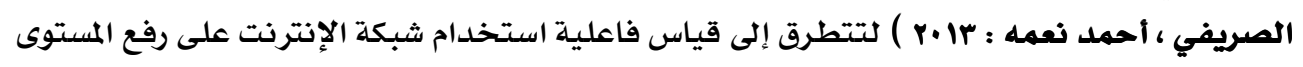

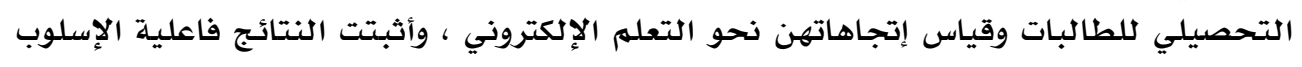
المستخدم يِ تحصيل الطالبات وتنمية إتجاهاتهن نحو التعلهم الإلكتروني .

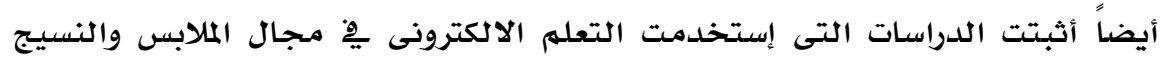

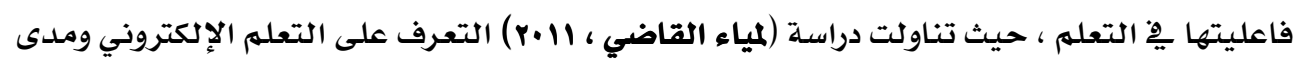

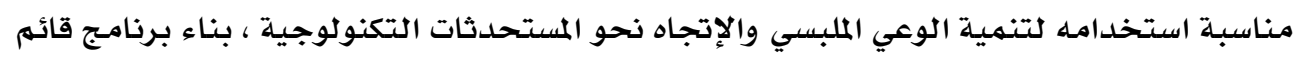

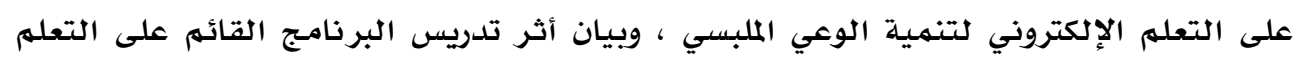

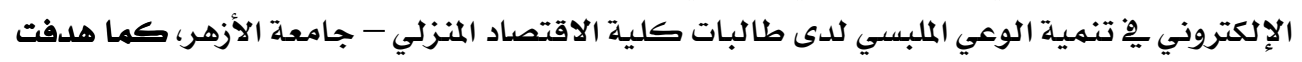

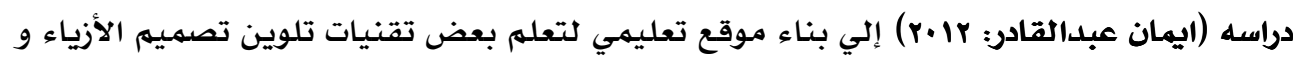

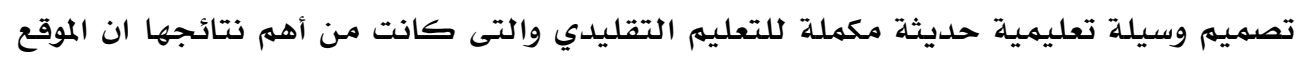




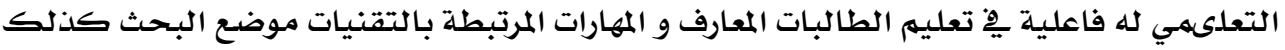

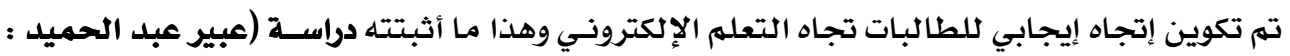

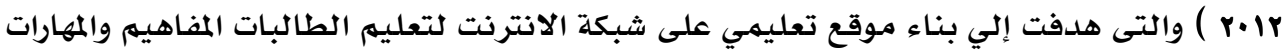

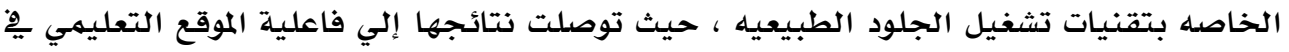

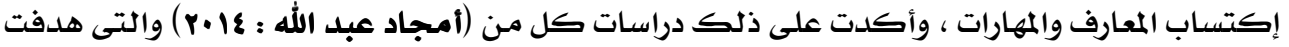

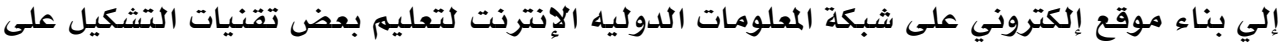

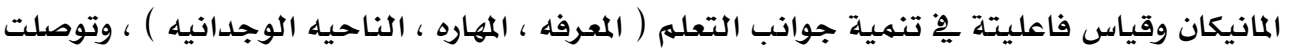

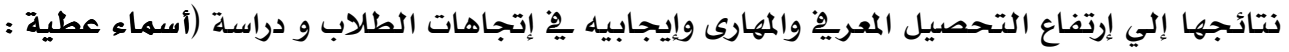

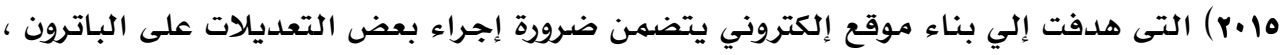

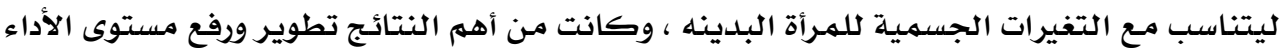

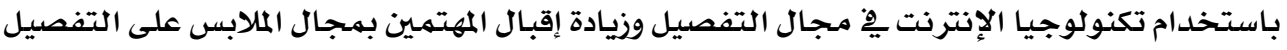

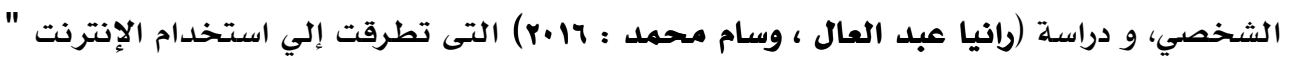

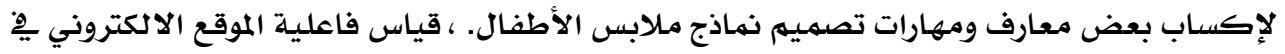

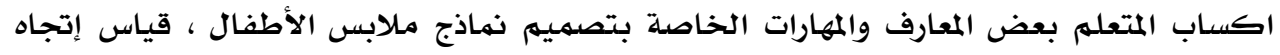

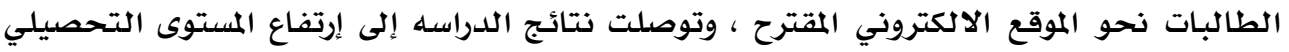

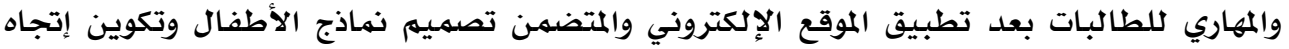

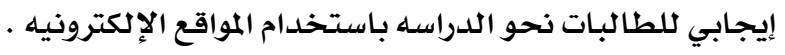

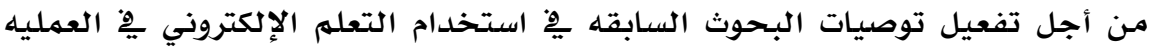

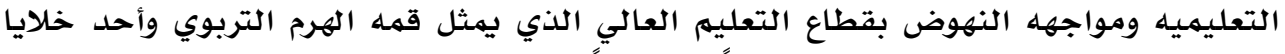

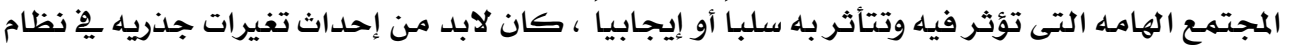

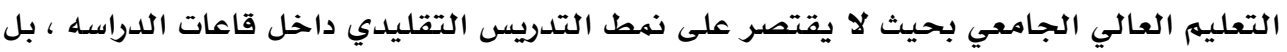

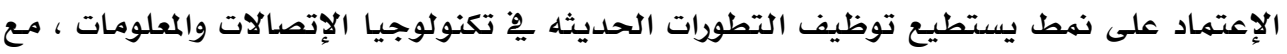

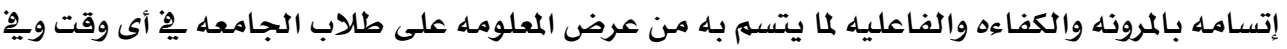

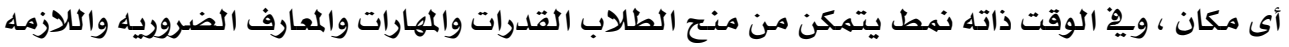

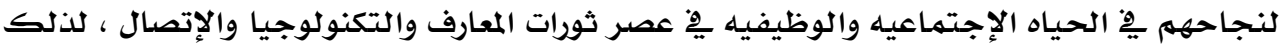

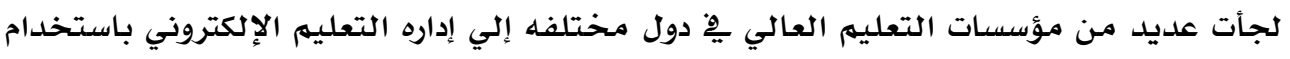

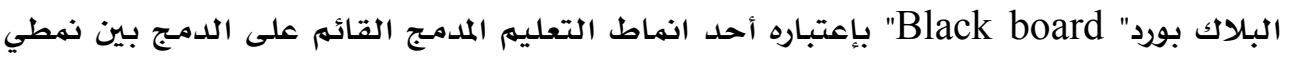

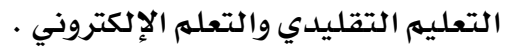

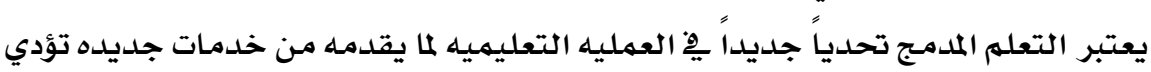

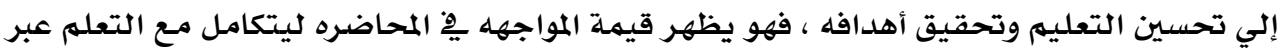

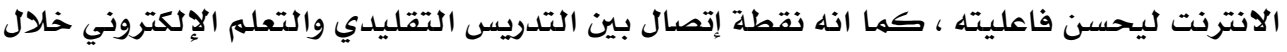

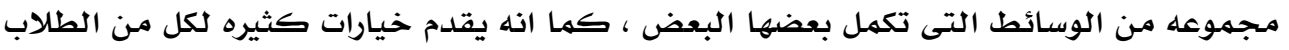

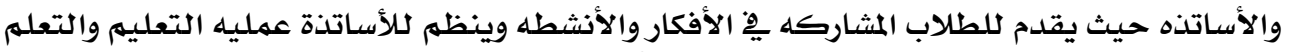


بصوره أفضل من خلال التغذيه الراجعه السريعه والتواصل المباشر مع الطلاب والمناقشات التأمليه والمشاركه الإفتراضيه.

(Morisse ,K \& others : 2009 )

لقد أثبتت كثير من الدراسات فاعلية نظام " البلاك بورد" يِّ تنميه كثير من القدرات

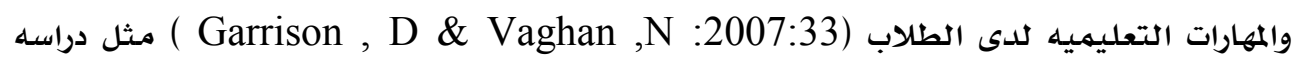
(Servon sky \& others : 2005)

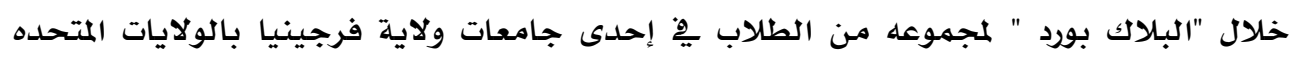

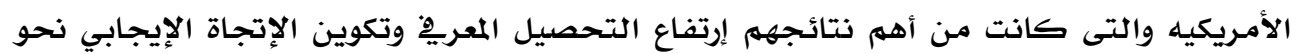

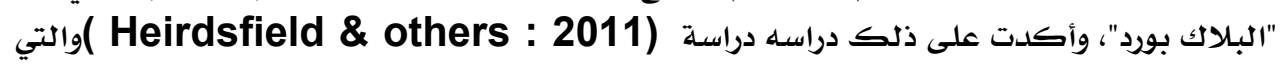

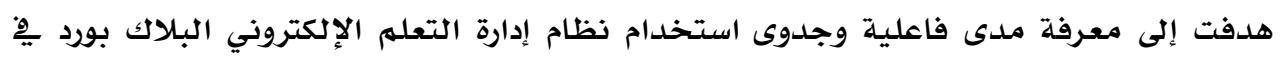

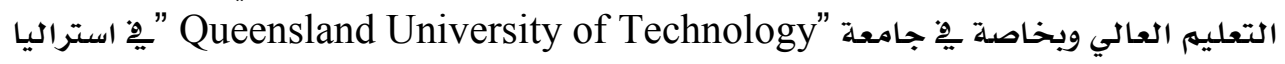
للطلاب والطالبات ، وأظهرت نتائج الدراسة ان نظام" البـالاك بورد " يجعل الطلاب وأعضاء هيئة

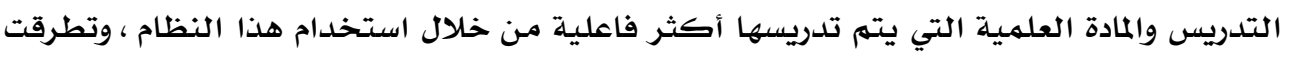

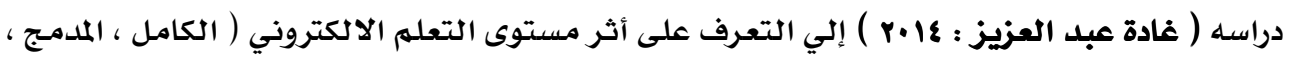

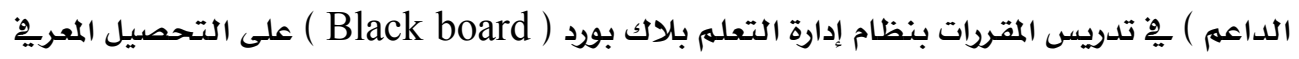

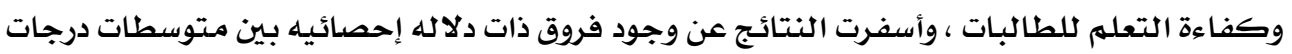

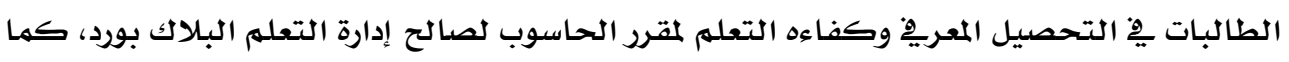

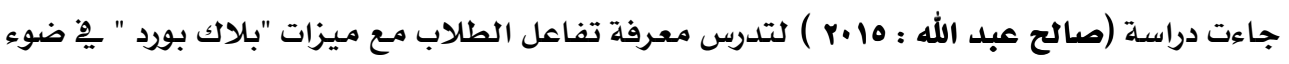

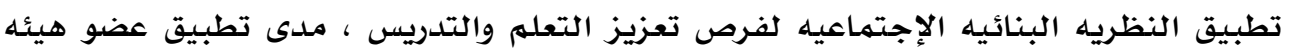

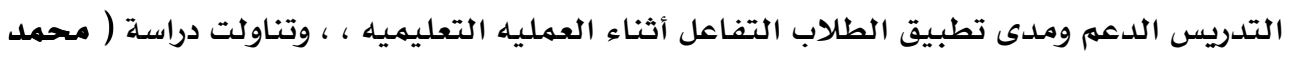

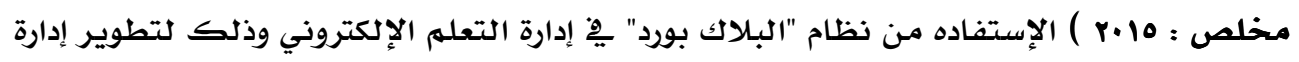

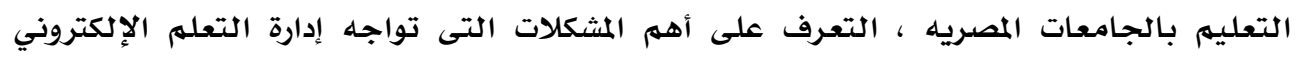

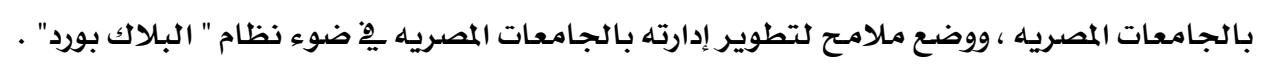

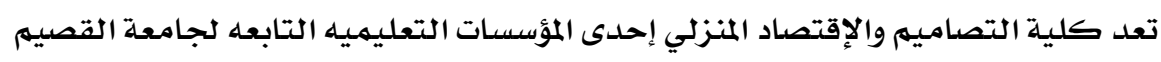

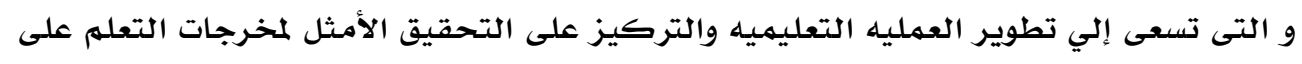

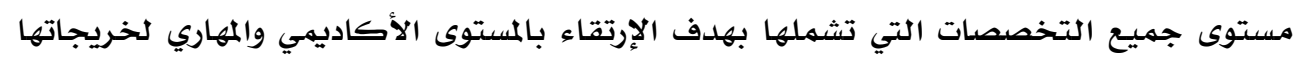

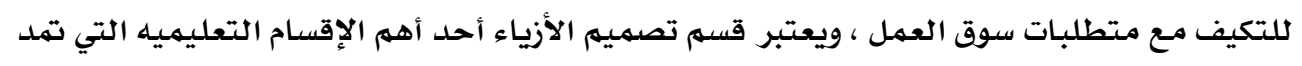

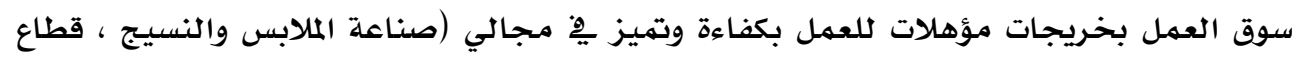

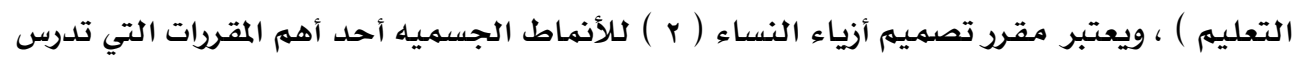

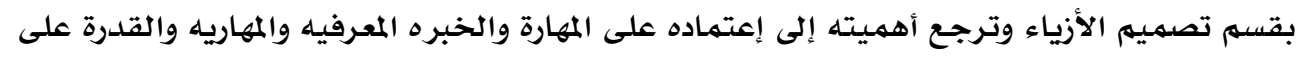

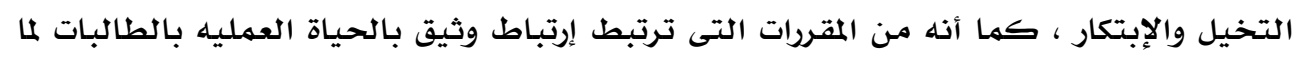

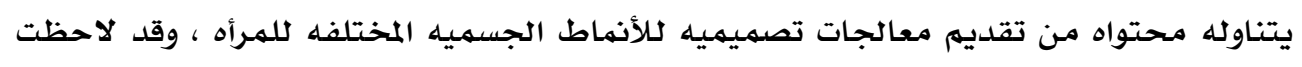


الباحثة أثناء تدريس مقررات تصميه الأزياء قصور ِِّ إتقان الطالبـات لرسم المعالجات التصميميه

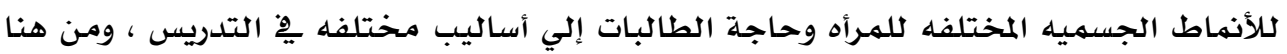

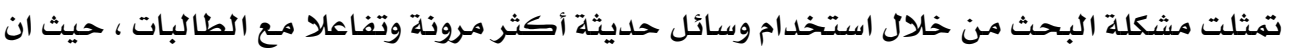

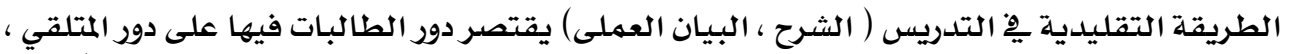

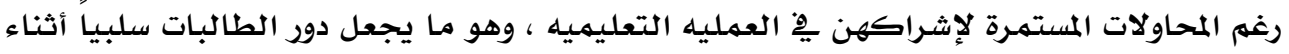

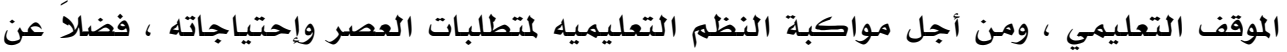

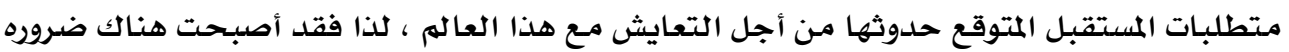

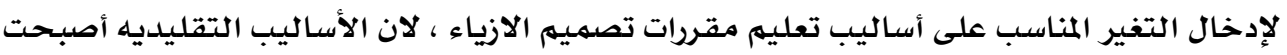

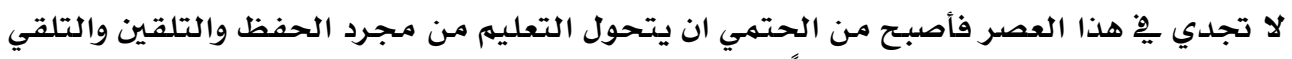

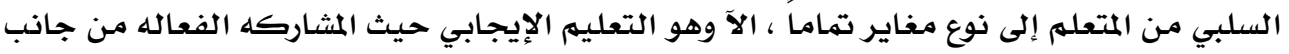

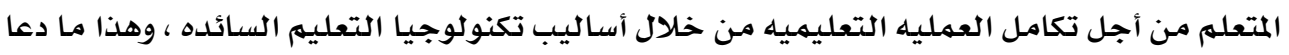

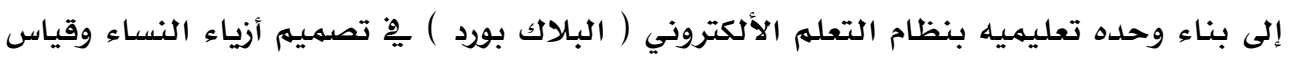

\section{وبِّ ضوء ما سبق عرضه يمكن تحديد مشكلة البحث بِ التساؤلات الآتيه :}

ا. مـا الخطوات العلمية التي تقوم عليها بناء وحده تعليميه بنظام التعلهم الأكتروني ( البلاك

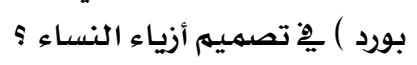

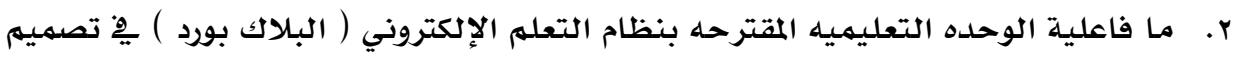

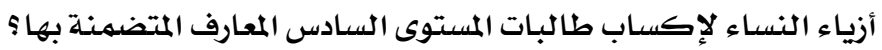

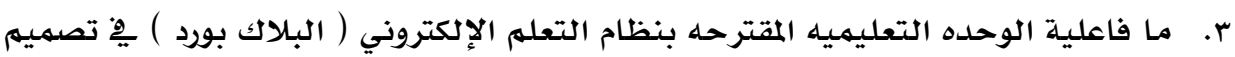

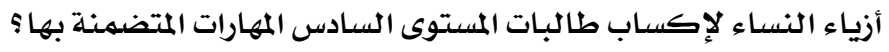

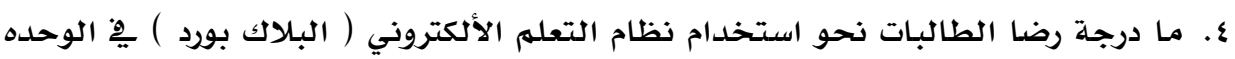

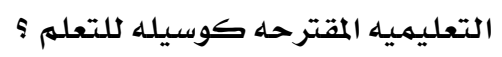

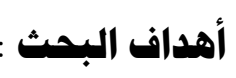

$$
\text { يهدف البحث إلى : بناء }
$$

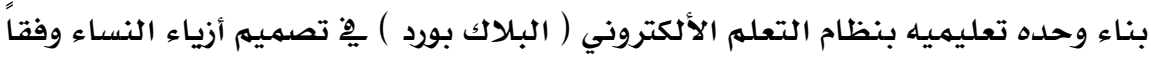

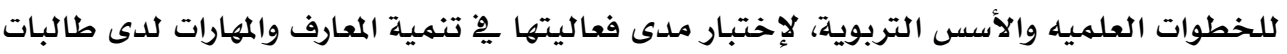

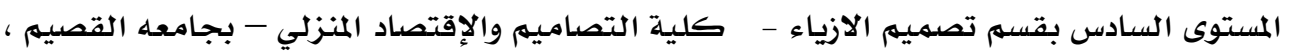

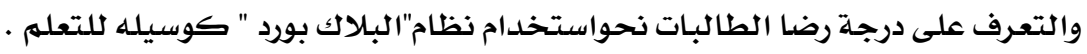

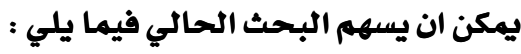

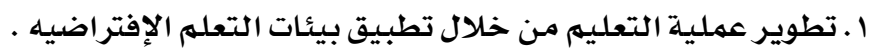


r. نشر ثقافة استخدام نظام إدارة التعلهم الألكتروني بلاك بورد " Blackboard " لدى الطالبات.

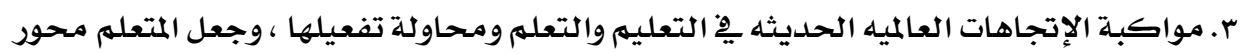

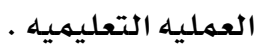

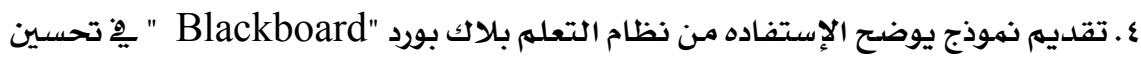

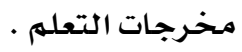

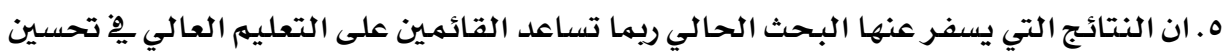

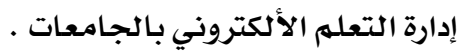

\section{إقتصر البحث الحالي على المحلددات التاليه :}

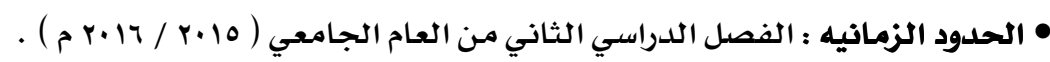
• الحدود المكانيه : جامعة القصيم ، كلية التصاميم والإقتصاد المنزلي ، قسم تصميهم الأزياء . • الحدود البشريه : (rV) طالبه من طالبات المستوى السادس بقسهم تصميم الأزياء . • الحدود التعليميه :

- وحدة من مقرد تصميم أزياء ( r ) والتي تدرس لطالبات المستوى السادس بقسم تصميم الأزياء

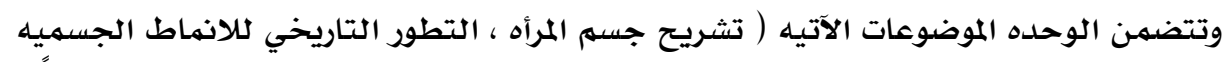

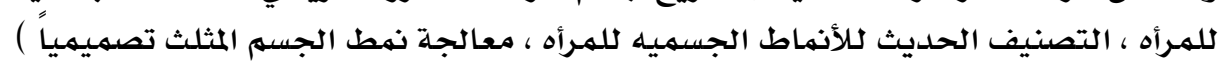

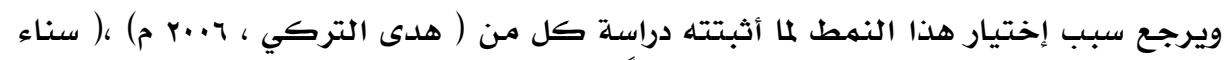

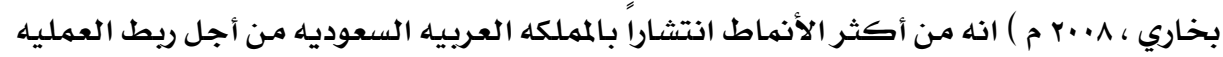

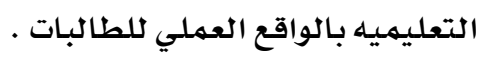

- نظام التعلم الأكتروني (البلاك بورد) المستخدم فِّ كلية التصاميم والإقتصـاد المنزلي بجامعة القصيه.

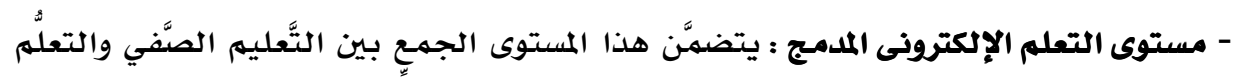

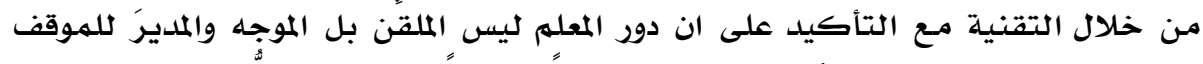

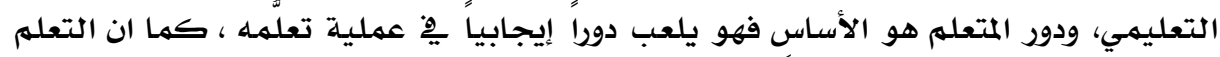

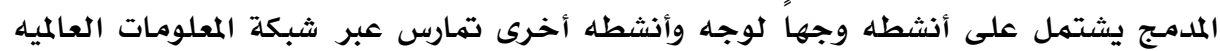

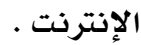




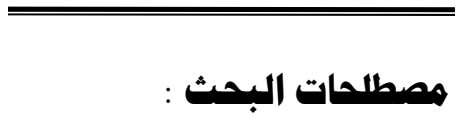

E-learning: التعلم الألكترونى

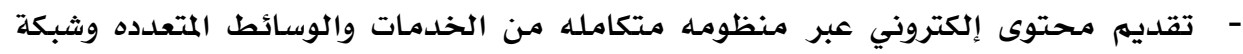

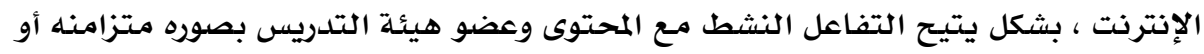

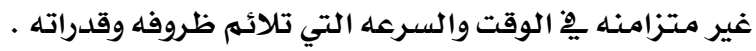

( ( حسن زيتون : r :

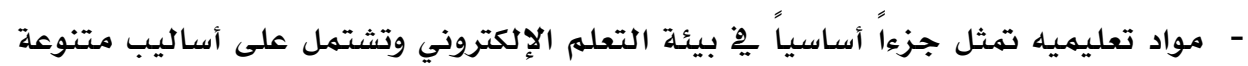

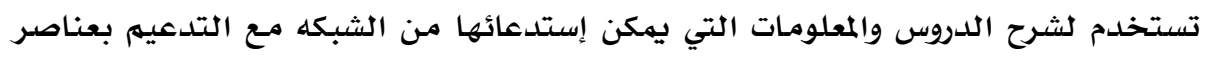
الوسائط المتعدده التفاعليه .

(Clarke, A : $2004: 120$ )

- طريقه للتعله باستخدام آليات الإتصال الحديثه من حاسب وشبكات ووسائط متعدده من

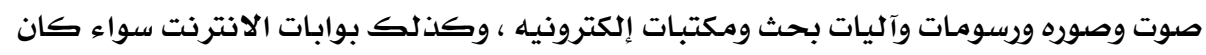

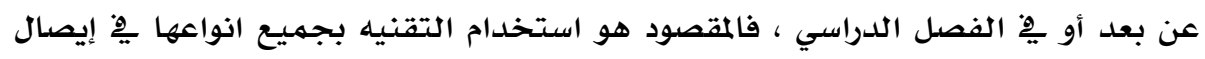

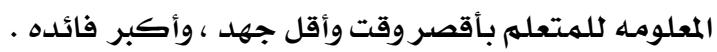

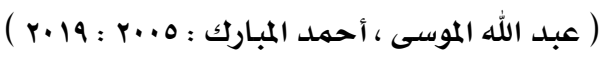

Learning Management System : نظم إدارة التعلم الإلكترونى اعبد اللموسى

برنامـج يتكون من ميـزات إلكترونيـه لعضو هيئـة التـدريس والمتعلهم يساعد على إدارة التعلهم

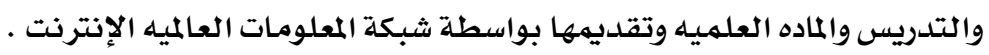

( Organization For Economic Co - operation and Development : 2005)

Blackboard: البلاك بورد

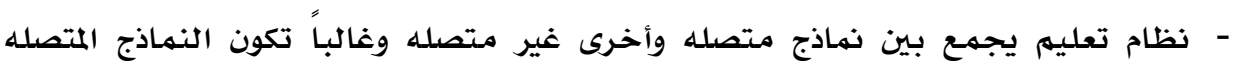

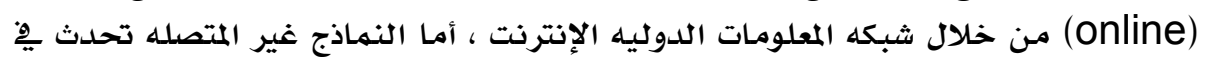

( Balci , M \& Soran, H : 2007 :41)

الفصول التقليديه .

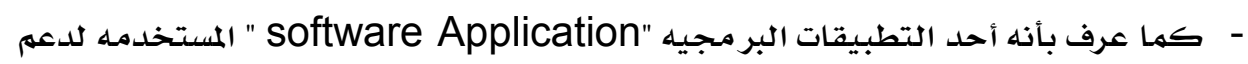

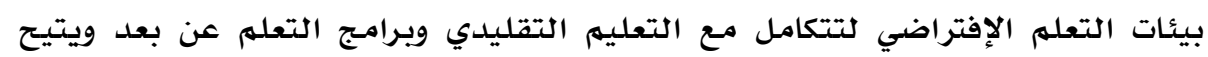

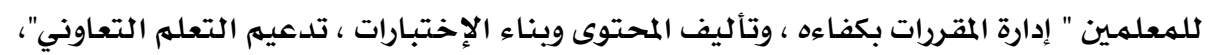

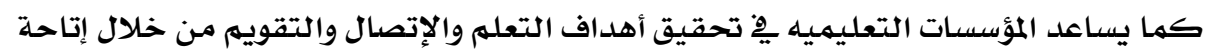

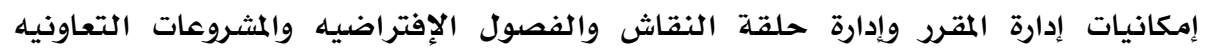

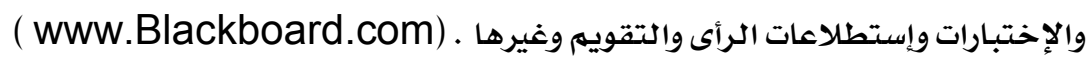


- وعرفه (138 : Martin , F : 2008 ) بأنه نظام إداره تعلم تجاري من شركه بلاك بورد " تمالم " Black board تعلىميه متنوعه من خلال كسر جميع الحواجز والعوائق التى تواجه المؤسسات التعليميه التريه

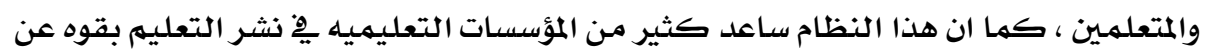

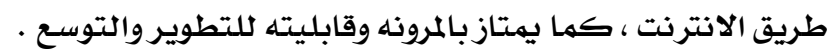

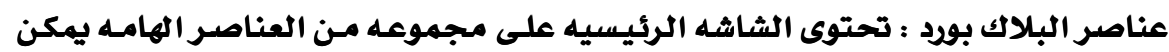
إيجازها يـ الآتي ، كما هو موضع بالشكل ( 1 ( ) :

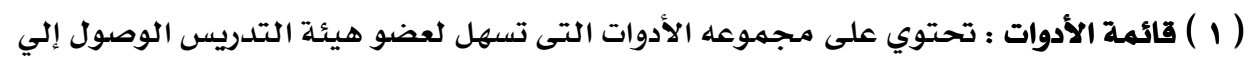

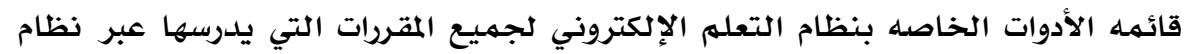

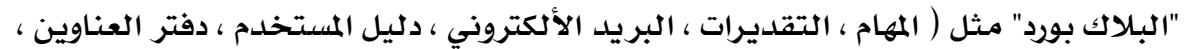

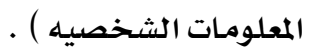

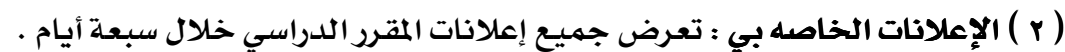

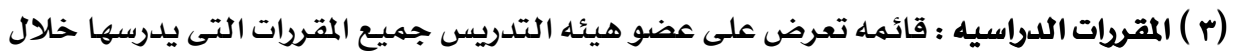

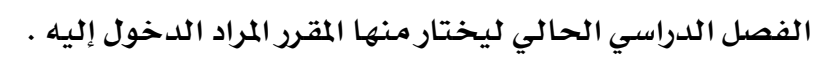

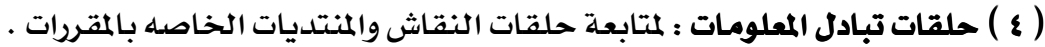

$$
\text { ( ) ) مهامي : تعرض المهام الخاصده بجميع المقررات . }
$$

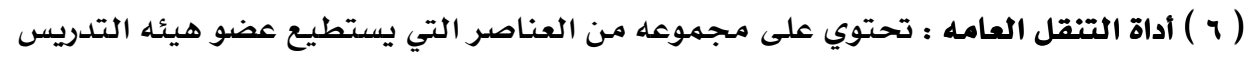

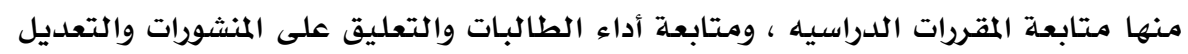

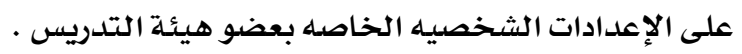
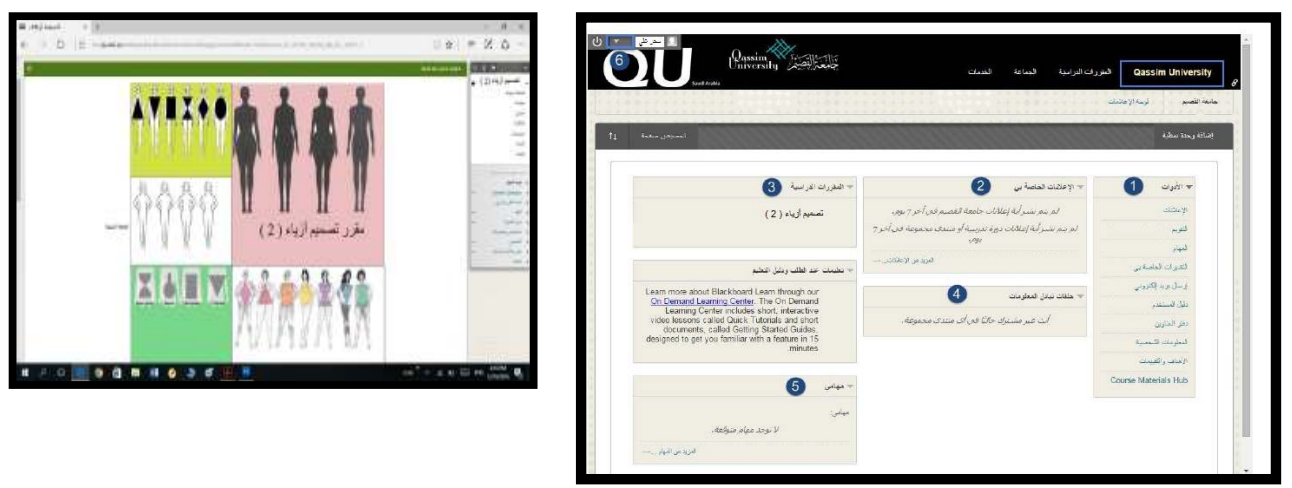

الشاشه الرئيسيه للبلاك بورد والمصمم بها شعار المقرد

شكل (1) 


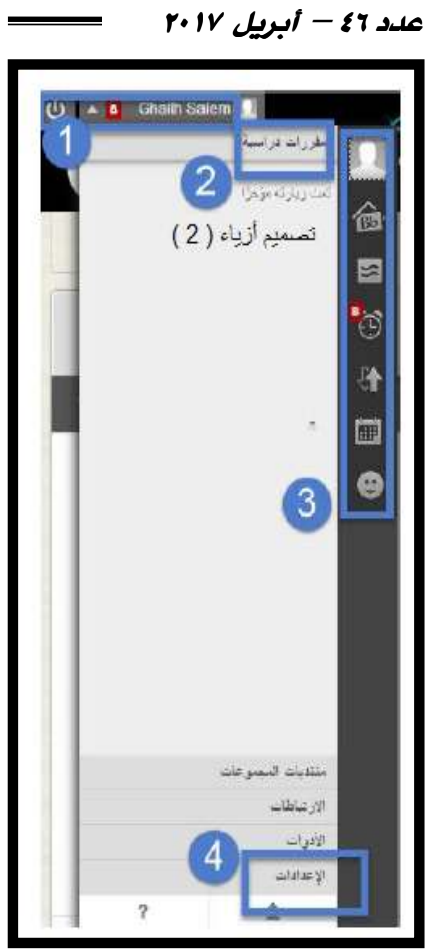

عناصر أداة التنقل

شكل (r) (r)

ويوضــح الـشكل (r) عناصـر أداه التتقـل العامـهـ والـتي

تتكون من :

ا ـ إسم عضو هيئة التدريس

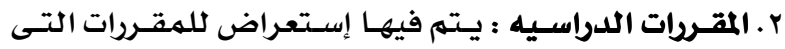

$$
\text { زارها عضو هيئة التدريس مؤخراً . }
$$

r. أدوات البلاك بورد : تحتوي على مجموعة الأدوات التي من

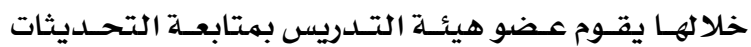

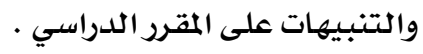

أ- التنبيهـات : يــتم فيهـا إسـتعراض تنبيهـات تـواريخ

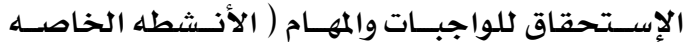

$$
\text { بالطالبات ). }
$$

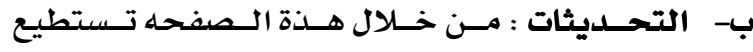

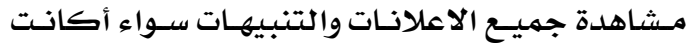

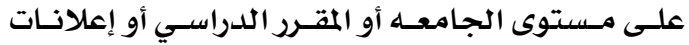

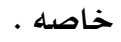

ع ـ الإعدادات : من خلالها يتمكن عضو هيئه التدريس التعديل

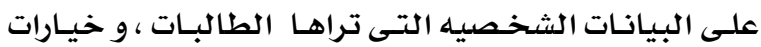

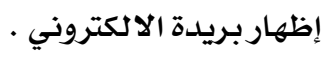

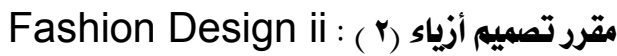

- مقرر يدرس لطالبات المستوى السادس ضمن برنامج بكالوريوس تصميه الازياء بكلية

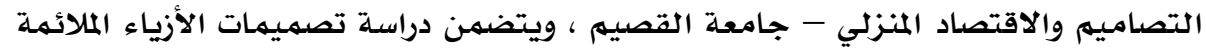

$$
\text { لكلانماط الجسميه للمرأة . }
$$

\section{Effectiveness : فاعليه}

- التطابق بين المخرجات الفعلية للنظام و المخرجات المرغوبه ، بهعنى مقارنة النتائج بالأهداف .

(كr. - 199V : (كوثر كوجك (r)

- القدره على إنجاز الأهداف أو المخرجات لبلوغ النتائج المرجوه والوصول اليها بأقصى حد المدئ ممكن - مa

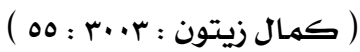

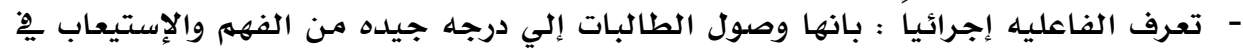

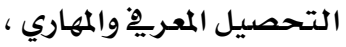




\section{بناء وحلد تعليمية بنظام التعلم الوكتروني (البلاك بورد) ف تصميم/زياء النساء وقياس فاعليتها}

وان يتكون لديهن إتجاه إيجابي نحو تصميه الأزياء للانهاط الجسميـه من خلال التعلهم عن

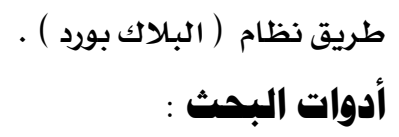

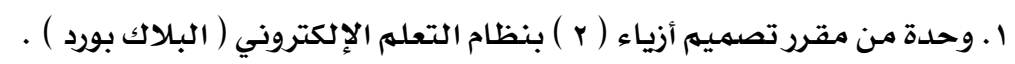

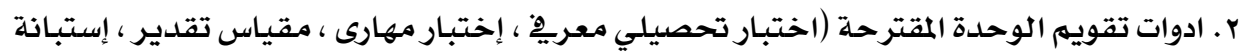

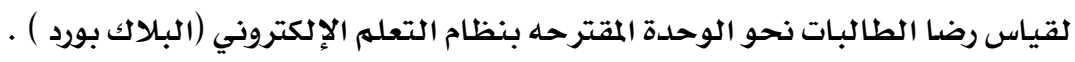

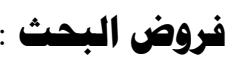

$$
\text { يختبر البحث صححة الفروض التالية: }
$$

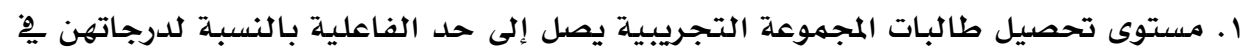

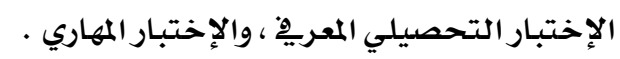

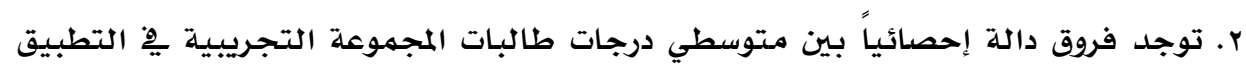

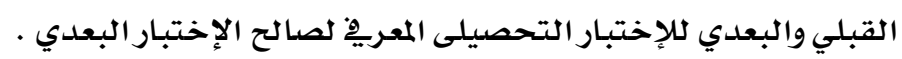

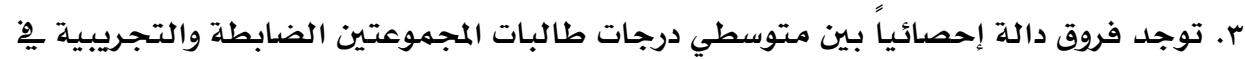

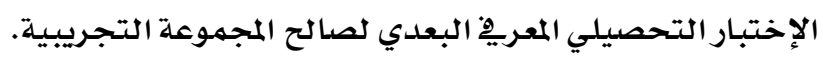

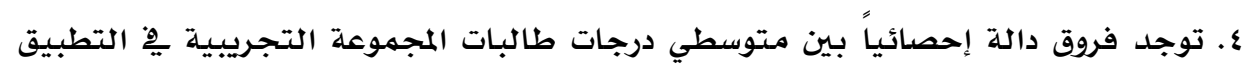

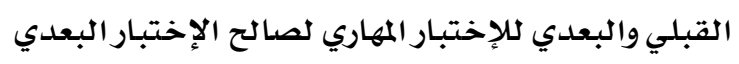

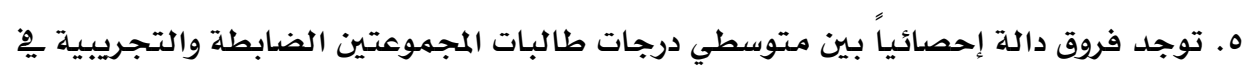

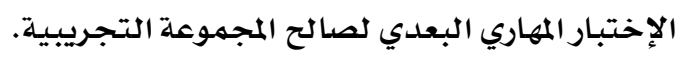

צ. إيجابية رضا الطالبات نحو استخدام نظام التعلهم الأكتروني ( البلاكك بورد ) يِّ تصميم أزياء النساء كوسيلة للتعلهم.

- المنهج الوصفي : من خلال تطبيق إستبانه للتعرف على درجة رضا الطالبات نحو استخدام

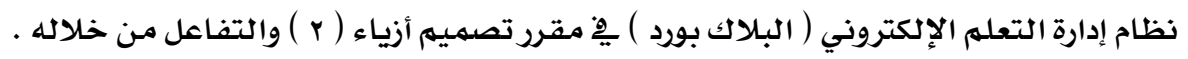

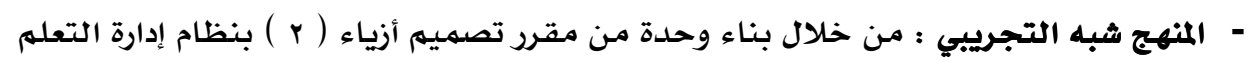

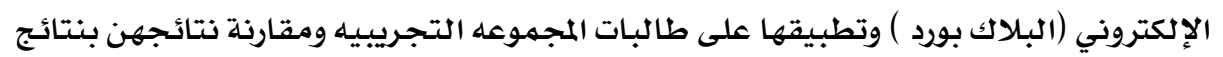

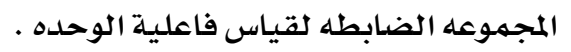

- المتغير المستقل : الموقع الإلكتروني التعليمي بنظام التعله الإلكتروني ( البلاك بورد ) لوحدة

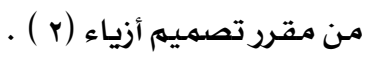




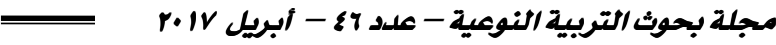

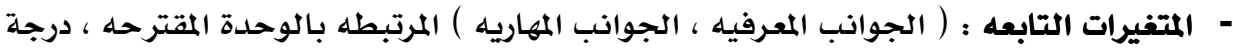

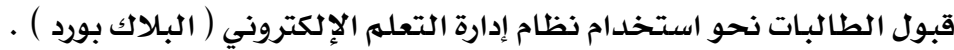

شملت عينة البحث بعض طالبات المستوى السادس " الفرقة الثالثه " بقسم تصميم الأزياء

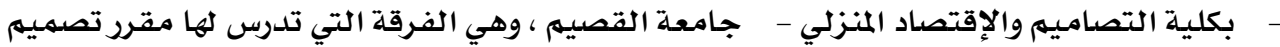

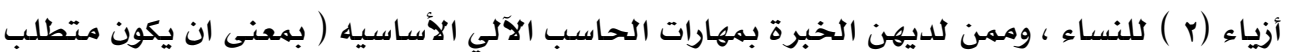

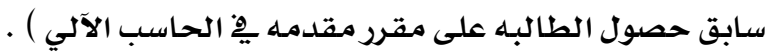

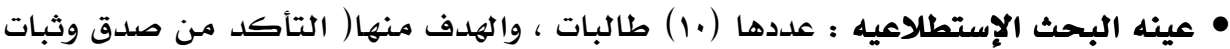

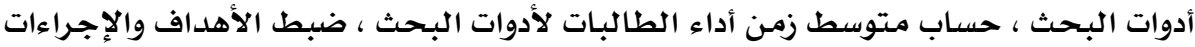

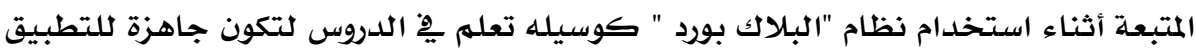
على عينة البحث الأساسية. • عينه البحث الأساسيه : عددها ( YV ) طالبه ، تم تقسيمهن عشوائيا إلي مجموعتين كالتالي:المجموعة الضابطة : تدرس بها الطالبات معالجة الانهاط الجسميه تصميمياً بأسلوب التعلم

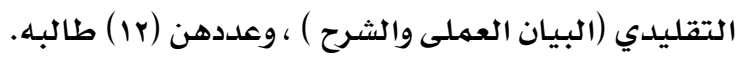

المجموعة التجريبية : تدرس بها الطالبات معالجة الانماط الجسميه تصميمياً من خلال

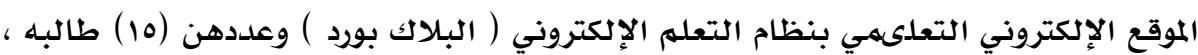

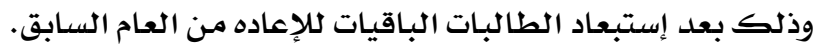

\section{للتحقق من صحة الفروض السابقة يمكن إتباع الآتى:}

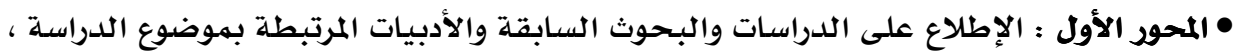

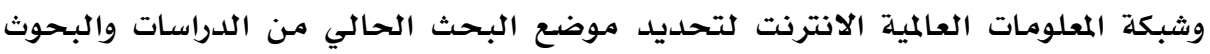

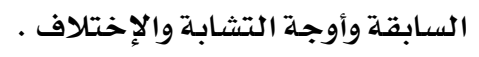

• المحور الثاني: خطوات بناء الوحده المقترحه بنظام التعلم الألكتروني ( البلاك بورد ) )ِّ تصميم

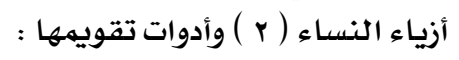

\section{اــ خطوات بناء الوحلدة المقتزحه : متوفرة بالتفصيل في ملحق (}

تمَّ الاعتماد أثناء تصميه وحدة من مقررتصميم أزياء (ץ) باستخدام نظام التعلمهم

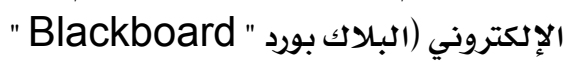

على معاييرّ أحد أبرز المؤسسات التي تُعنى بجودة تصميم المقررات الإلكترونية وهي

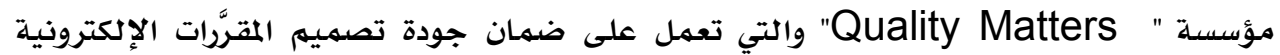




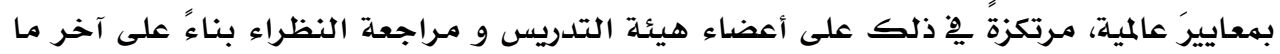

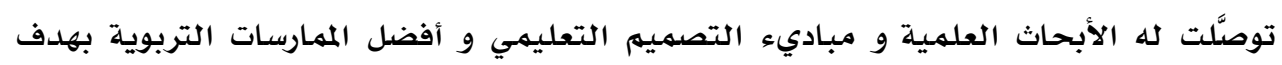

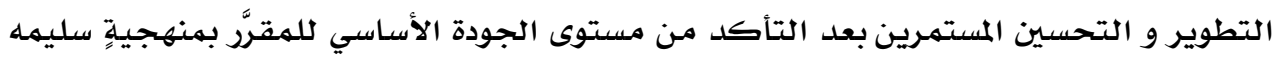

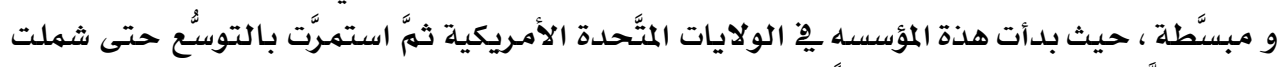

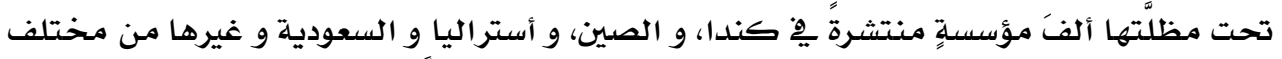

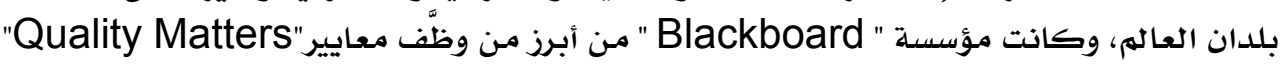

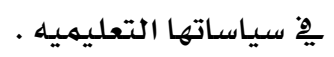

وفيما يلي توضيح مختصر لمكونات وخطوات بناء الوحدة الإلكترونيه الموضحه ببعض المض المئه

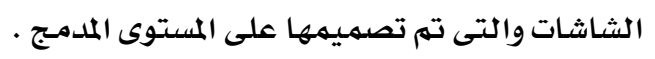

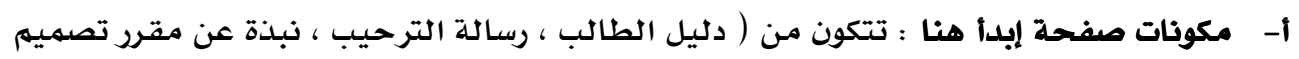

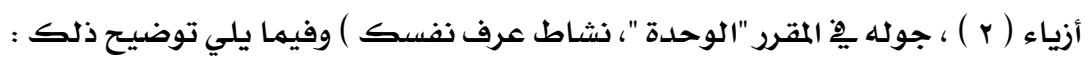

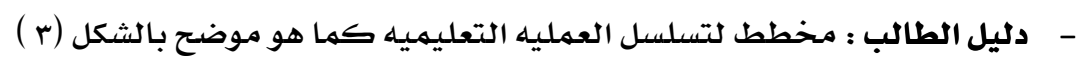

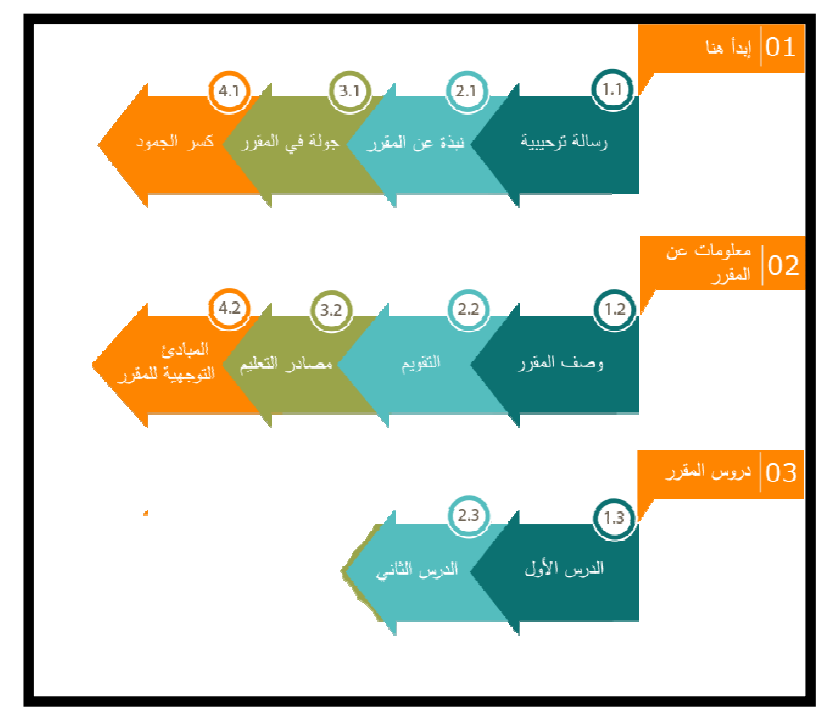

\section{شكل توضيحي لدليل الطالب}

شكل (r)

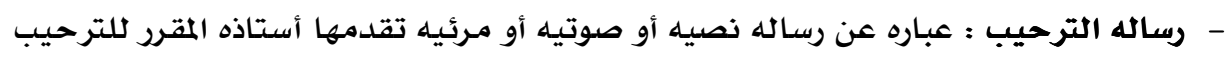

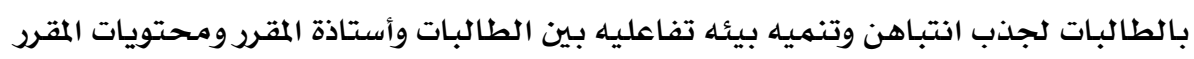

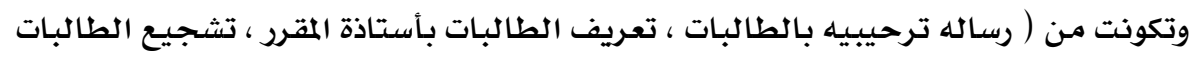

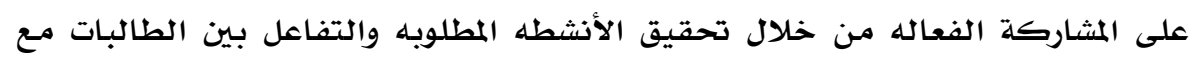

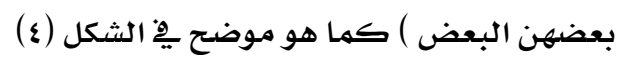




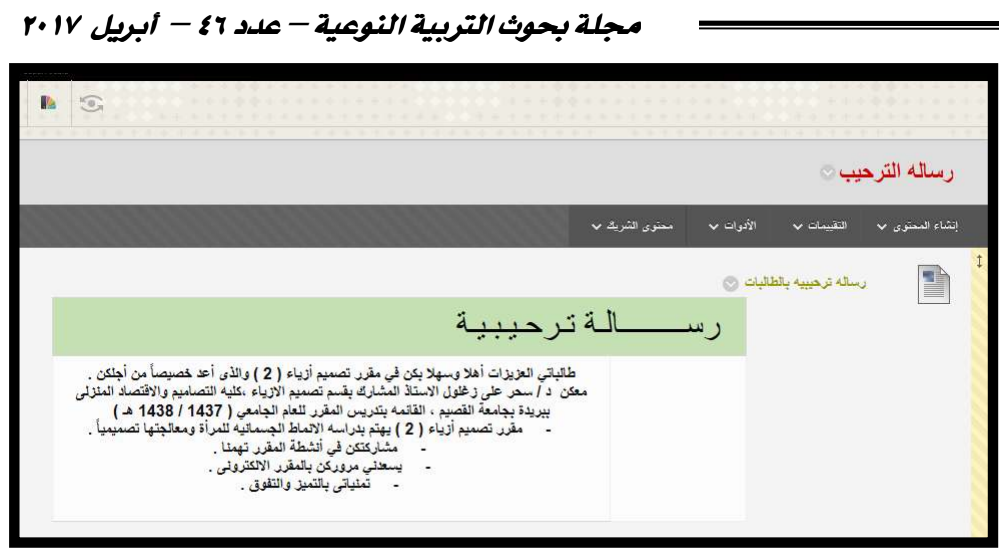

شاشه توضح الرساله الترحيبيه

شكل ( ) ع ( )

- نبذة عن الوحدة المقترحه: بهدف مد الطالبات بالمعلومات الأساسيه عن الوحلدة المقترحه

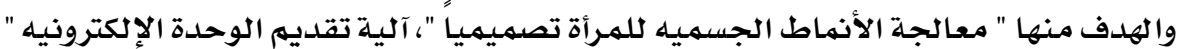

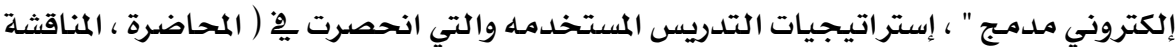

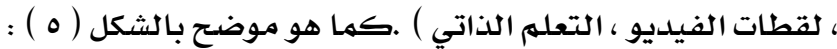

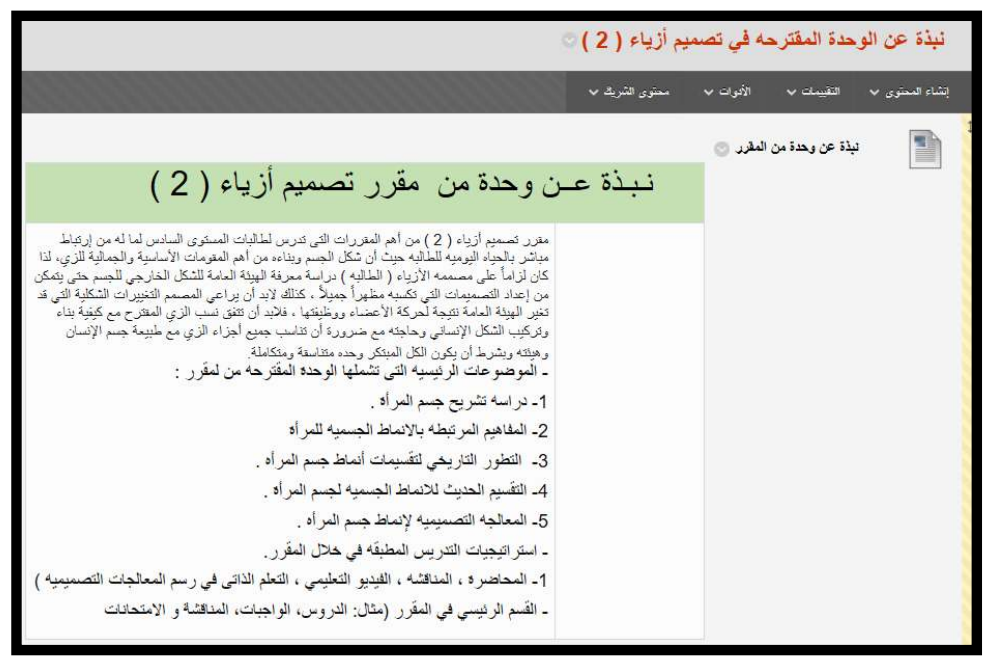

ثـاثه توضح نيذة عن الوحده المقترحه

شكل (0)

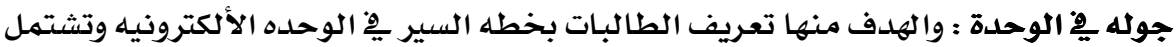

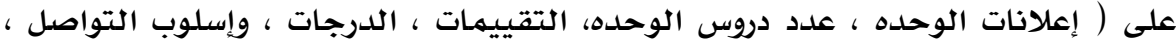

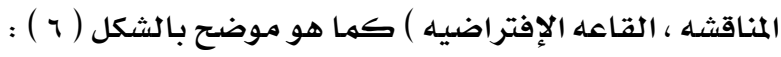




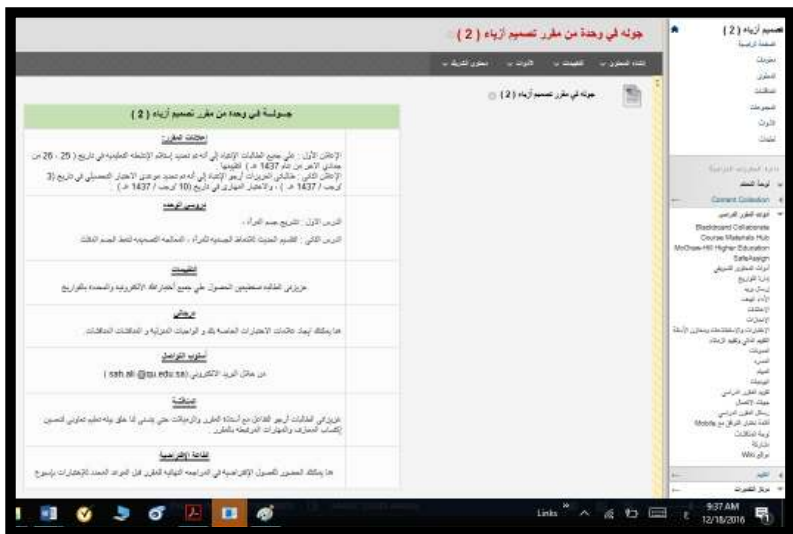

شاشه توضع جوله يـ الوحلده

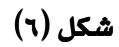

- نشاط عرف نفسك : من خلال انشاء منتدى للتعارف بين الطالبات ، وطرح بعض الأسئله

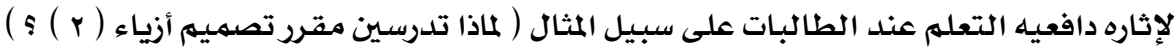
ب- مكونات صفحة دليل الوحده : تتكون من ( معلومـات الوحدة المقترحه ، معلومات عضو هيئة

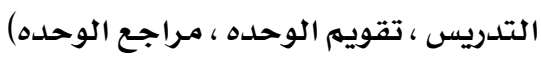

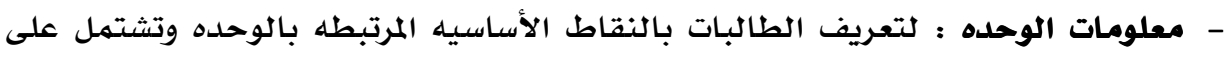

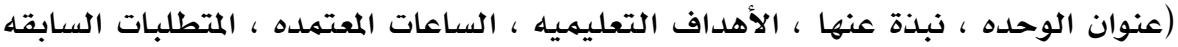

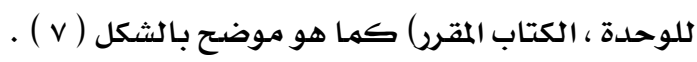

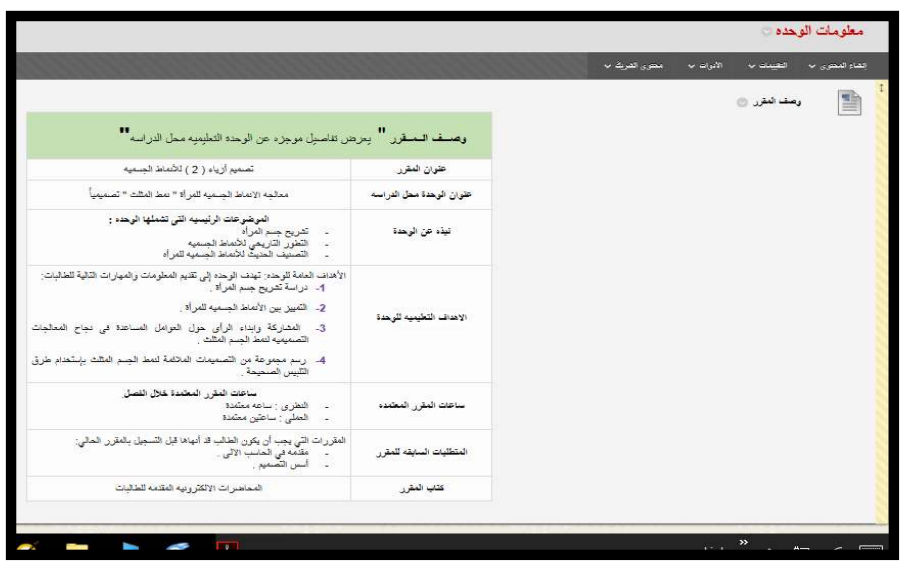

ثـاثه توضح معلومات الوحده

شكل (v) 
ب مجلة بحوث التربية النوعية - علد I? - أبريل r.lV

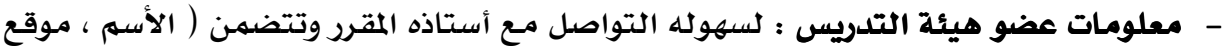

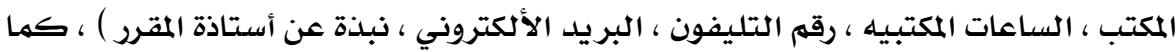

هو موضح بالشكل ( 1 ) .

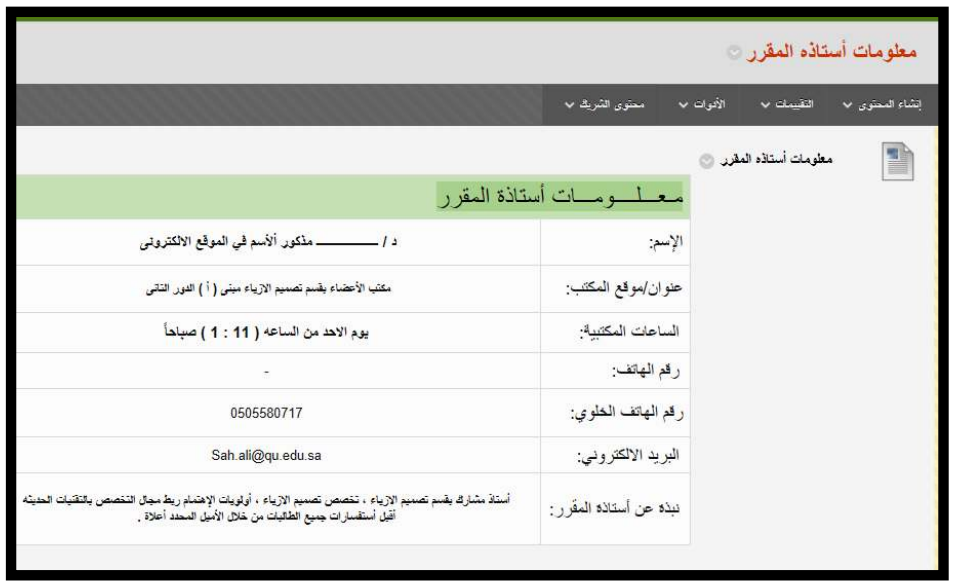

شاشه توضيح أستاذة المقرد

(ی) شكل

تقويم الوحدة : لتعريف الطالبات بالخطة الزمنيه للوحده المقترحه بحيث تتضمن

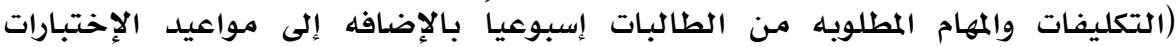

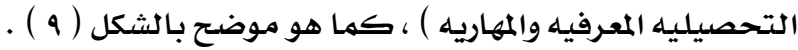

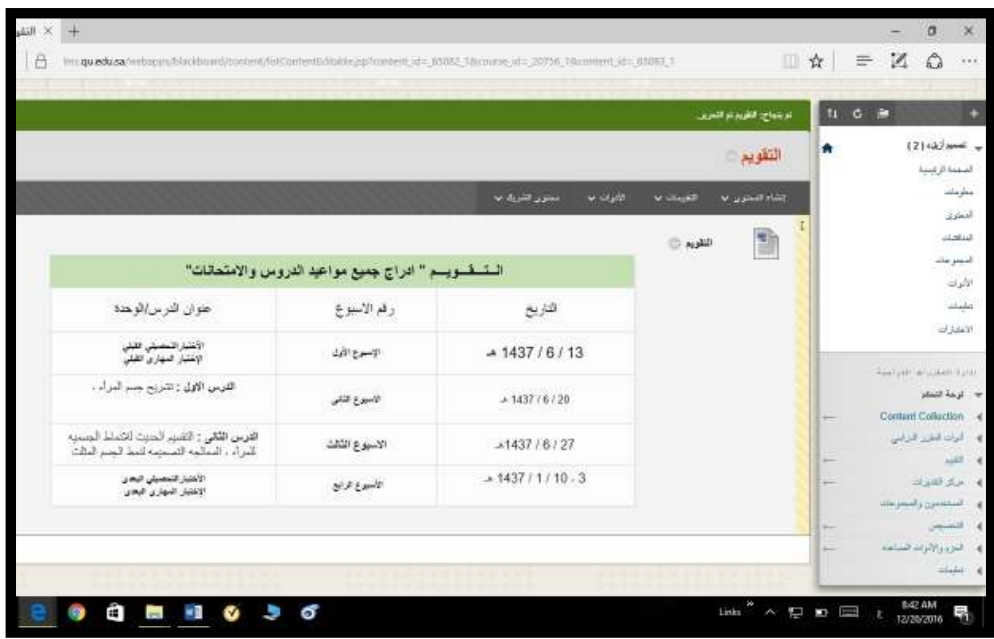

ثاشه توضح الرساله الترحيبيه

(4) شكل (a) 
- مراجع الوحدة ( مصادر التعلم ) : تحدد الكتب والمراجع ( الرئيسيه ، الضروريه ، الموصى بها )

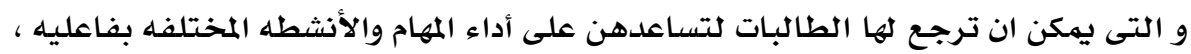

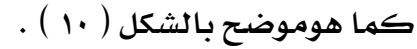

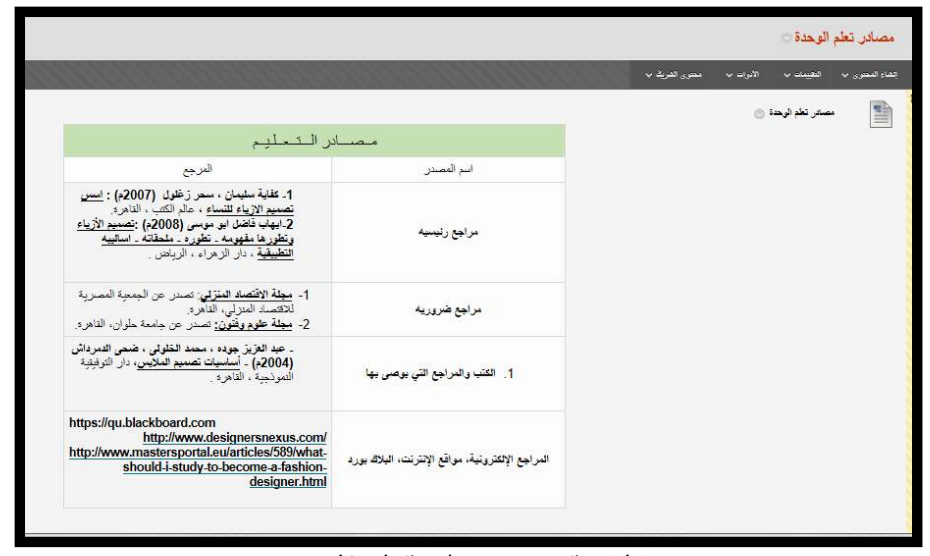

ثاشـه توضتح مصادر تعلم الوحلده

(1.) (1)

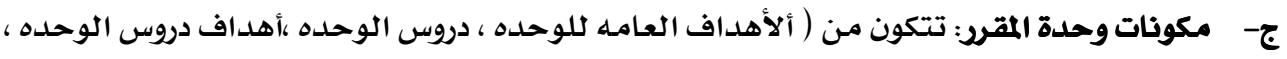

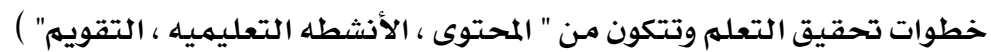

- الأهداف العامه للوحده : تم تحديد الأهداف العامـه للوحده وهى كالآتى ( دراسـة تشريح

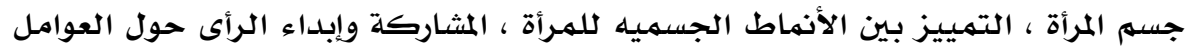

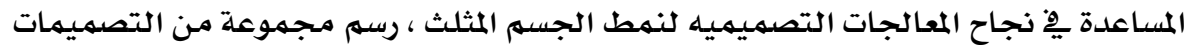

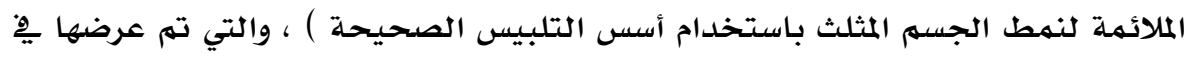

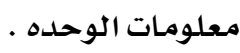

- دروس الوحدة : تتكون الوحدة من درسين بحيث يمثل كل درس خبرة تؤدي إلي خبرة تالية

$$
\text { تبني عليها . }
$$

•الدرس الاول : تشريح جسم المرأه والتطور التاريخي لأنماطها الجسميه .

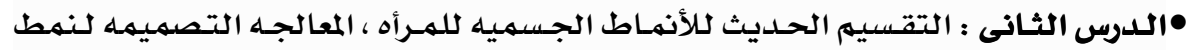

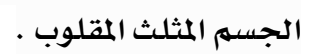

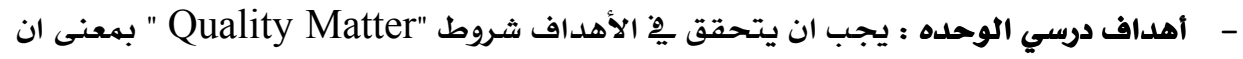

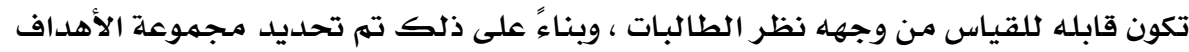

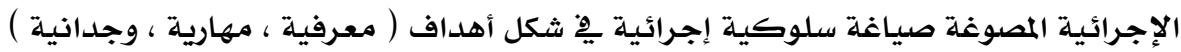

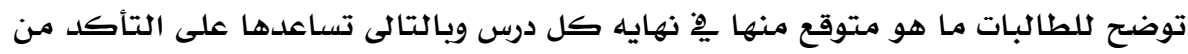

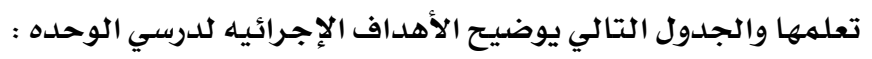


جدول ( 1 ) الأهداف الإجرائيه لدرسي الوحده

\begin{tabular}{|c|c|c|}
\hline الأهداف الوجدانيه : تستطيع الطالبه بعـد & تالأهــاف الـنفس - حركيـهـ : & بالأهداف المعرفية : تستطيع الطالبه بعد المرور \\
\hline 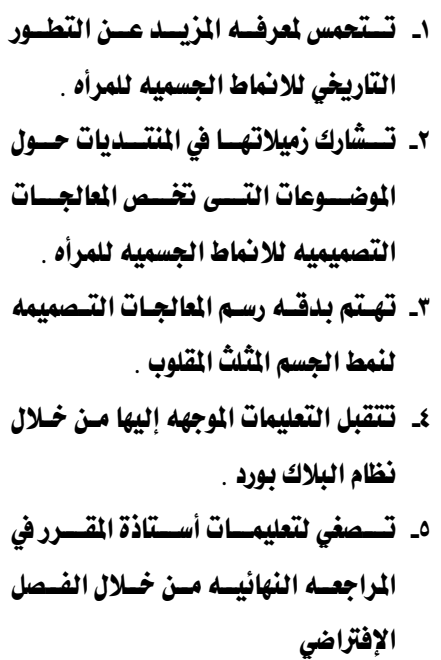 & 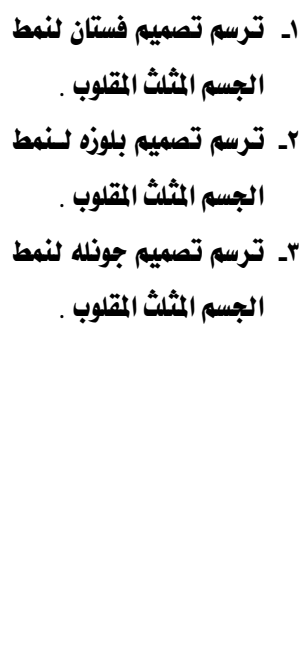 & 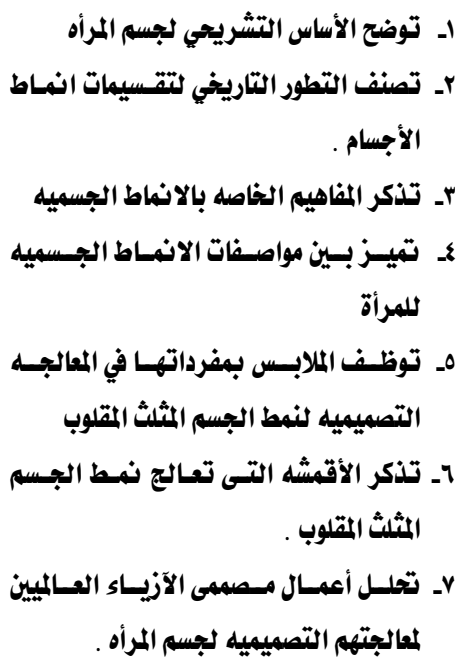 \\
\hline
\end{tabular}

- خطوات تحقيق التعلم وتتكون من " المحتوى ، الأنشطه التعليميه ، الوسائل التعليميه، التقويم " :

المحتوى : تم تحديد محتوي درسي الوحدة المقترحه فِ ضوء الأهداف الإجرائيه المراد تحقيقها والمدى الزمني المتاح لتنفيذها ، وذلك بالإستعانة بالمراجـع العلمية ( الأساسيـه ، الضروريـه ، الموصي بها ) مِّ مجال تصهيه الأزياء من أجل بناء المحتوي العلمي الخاص بالوحدة موضوع الدراسلة ، وقد تم تنظيم محتوى درسي الوحدة ِِ تتابع منطقي من البسيط إلي المركب ليتدرج ِِِ العمق بما يحقق التكامل بين الإطارين المعربِ والمهاري ليحقق كل درس خبرة تؤدي إلي خبرة تالية تبني علىها ، تم تقديه المحتوى العلمي للوحدة المقترحه

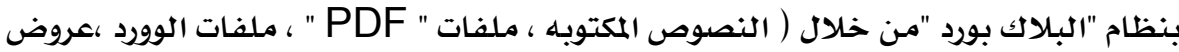
تقديميـه ، لقطات فيديو تم تنفيذها بإستراتيحيات تعليميـه " المحاضره ، المناقشه ، عروض تقديهيـ" ) مـع مـراعاه إنثاء تقويم تكويني (مرحلى) لكل معلومهـ مقدمهـ لتحفيز الطالبـات

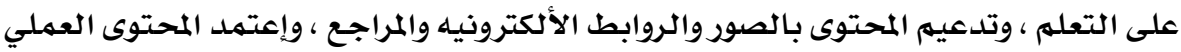
على التعليهم المبرمـج طريقة للتعلهم الذاتي، تقسه فيها المادة الدراسية بطريقة منطقية إلى

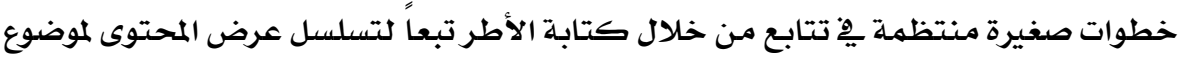
(رسم معالجـات تصميهيـه لنهط جسهم المرأه المثلث المقلوب)، ولمسـاعدة الطالبات على التركيز وعدم التشتت وضع كل إطار يِ صفحة منفصلة ضهانا لعدم قراءة أى إطار إلا بعد الانتهاء 
من تعلهم محتوى الإطار الذى تتناوله الطالبه، واحتوى الإطار على معلومـة تقرأها الطالبه

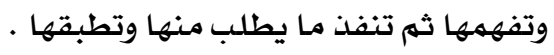

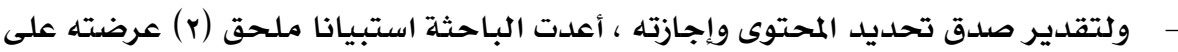

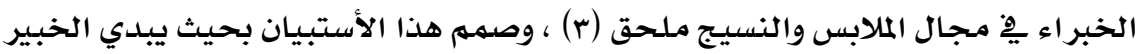

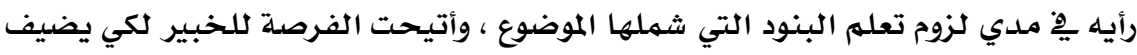

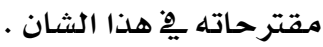

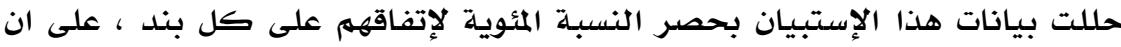

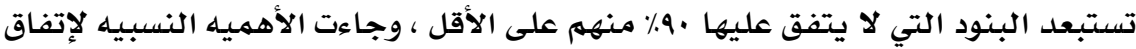

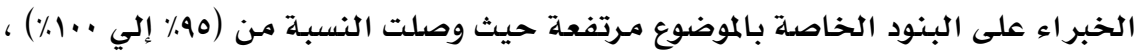

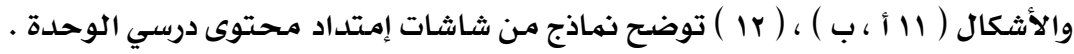

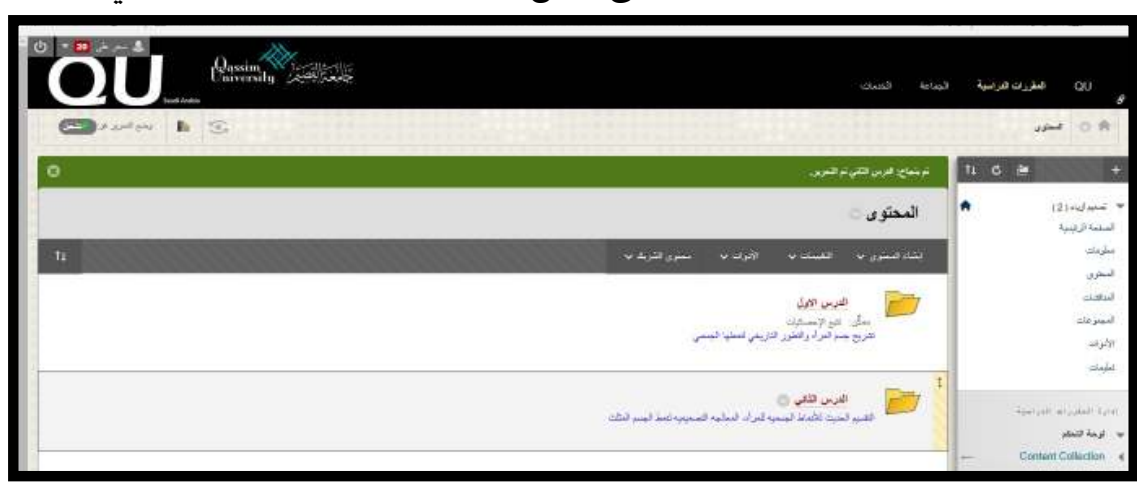

شكل (iil)

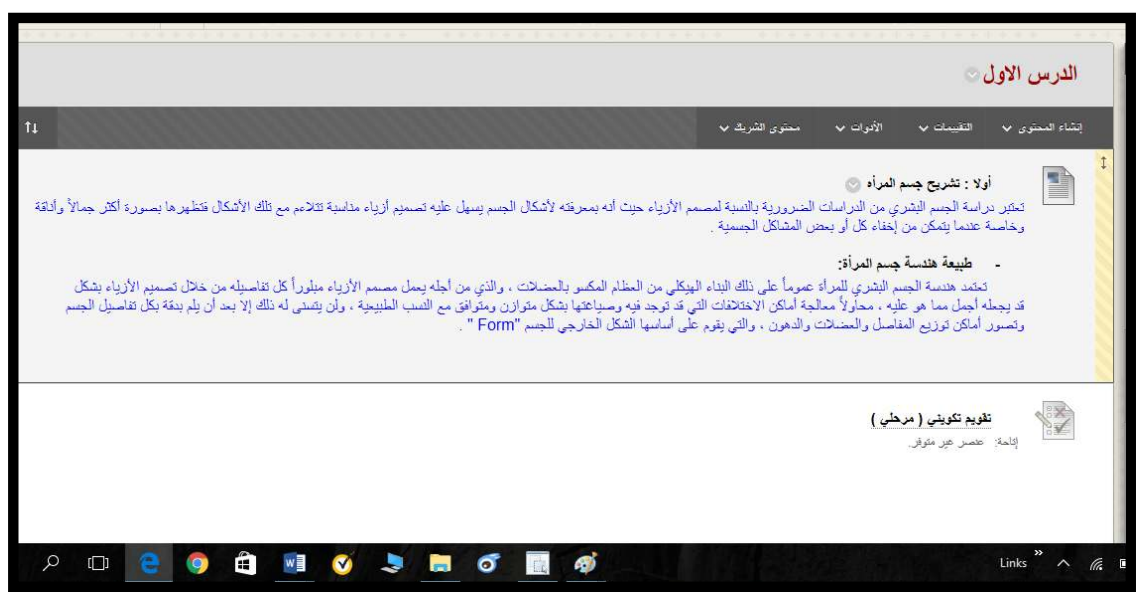

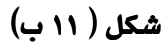

نماذج من شاشات نظام البلاك بورد توضح إمتداد المحتوى النظرى لدرسي الوحده التعليميه

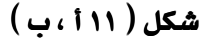


مجلة بحوث التربية النوعية - علد rأ - أبريل r.lV

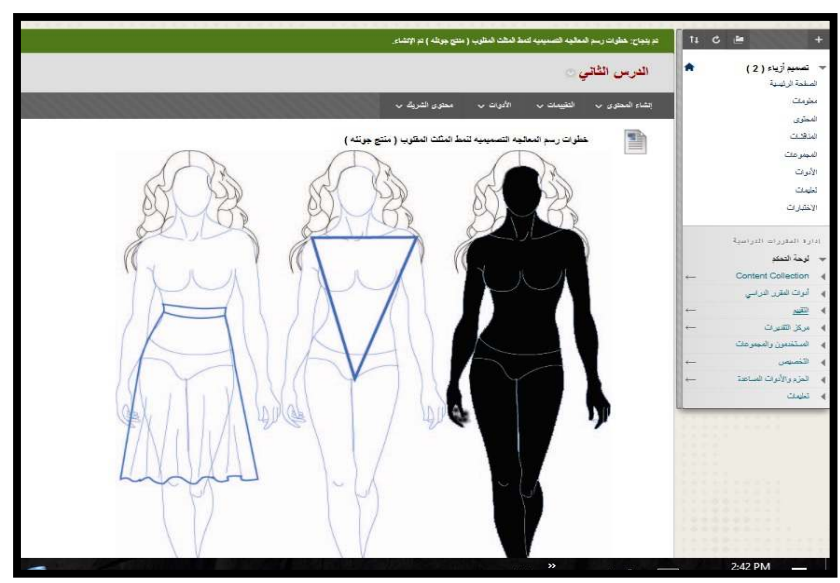

شاشه توضح نموذج من المحتوى العملي

شكل (ir)

• الأنشطه التعليميه : لابد ان يتوفر فيها ( إرتباطها بالاهداف التعليميه ، تاريخ البدايه

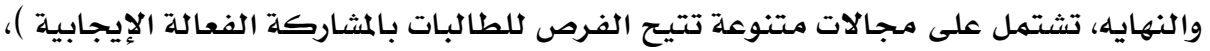

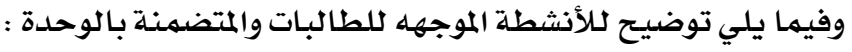

$$
\text { أنشطه تزامنيه : }
$$

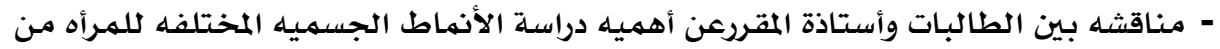

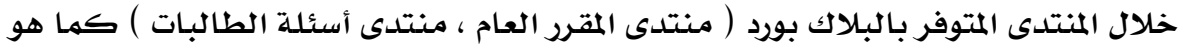

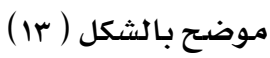

$$
\text { أنشطه غير تزامنيه : }
$$

- تلخيص المعلومات الخاصده بتشريح جسهم المرأه .

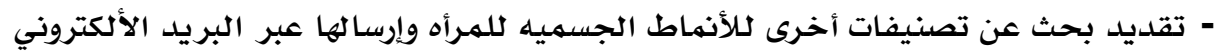

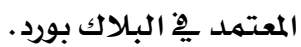

- إبداء الرأى ِِّ أعمال الطالبات الخاصده بالمعالجات التصميمها وفق معايير أسس التلبيس

$$
\text { الصحيحه . }
$$

- التدريب المستمر على رسهم معالجات تصميميه لنمط الجسم المثلث المقلوب وإرسالها عبر

نظام البلاكك بورد. 


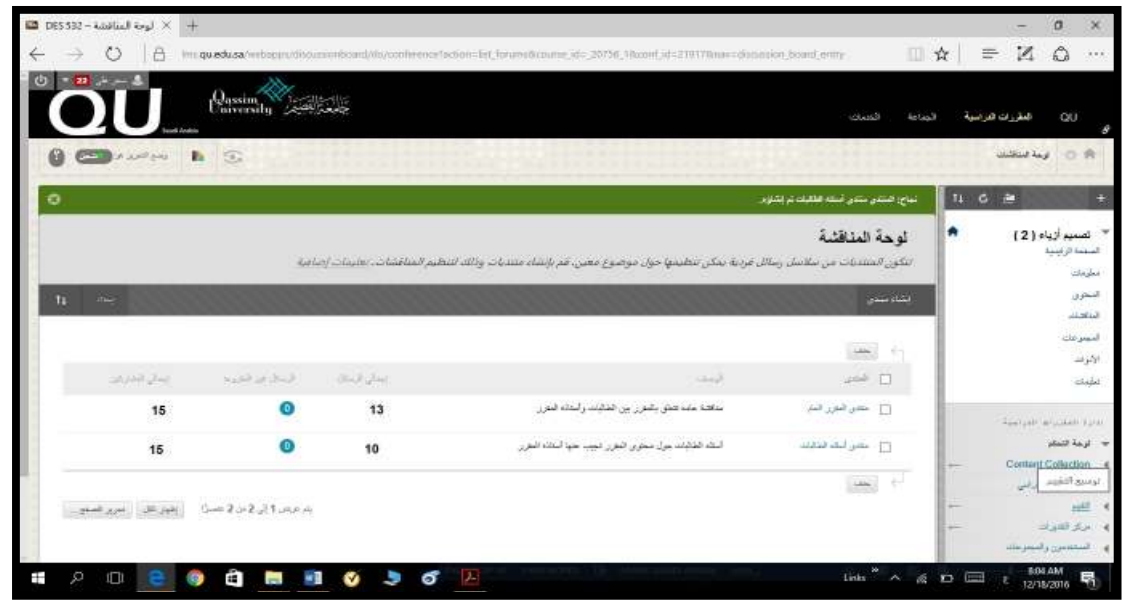

ثـاشه توضتح لوحه مناقشات الوحلدة المقترحه بين الطالبات وأستاذة المقرد

شكل (ir)

• التققويه :

تحديد أساليب التقويم : استخدم ثلاثه أنواع من التقويه كالتالي :

تقويم تشخيصي " قبلي " : بهدف معرفة معلومات ومهارات الطالبات قبل البدء يِّ تطبيق

درسي الوحدة المقترحة وذلك من خلال تطبيق كل من ( الإختبار ألتحصيلي المعريفه ، الإختبار المهاري ، مقيـاس التقدير ) قبلياً .

تقويم تكويني " مرحلي " : تتم بصوره دوريه متكرره بشكل مـلازم للعمليه التعليميـه منذ

بلدايتها وذلك من أجل التعرف على مستوى تحقيق الطالبات لأهداف الوحدة وتتهثل يِ

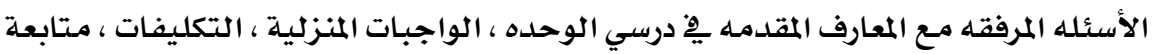
أداء مهارات رسم المعالجات التصميهيه لنمط جسم المرأة المثلث المقلوب ) .

تقويم تجميعي " نهائي " : بهدف قياس تحصيل الطالبات للمعارف والمهارات المتضهنـة بالوحدة الإلكترونيه المقترحة وكذلك معرفة درجه رضاهن نحوها بعد إجراء التطبيق ، وتم ذلك عن طريق تطبيق كل من ( الإختبار ألتحصيلي المعريخ ، الإختبـار المهاري ، مقياس التقدير ، مقياس الإتجاهات ) بعديا . والشكل (عال (1) يوضح نشر الإختبـارات التحصيليـه المعرفيـه والإختبـارات المهاريه على نظام البـلاك بورد . 


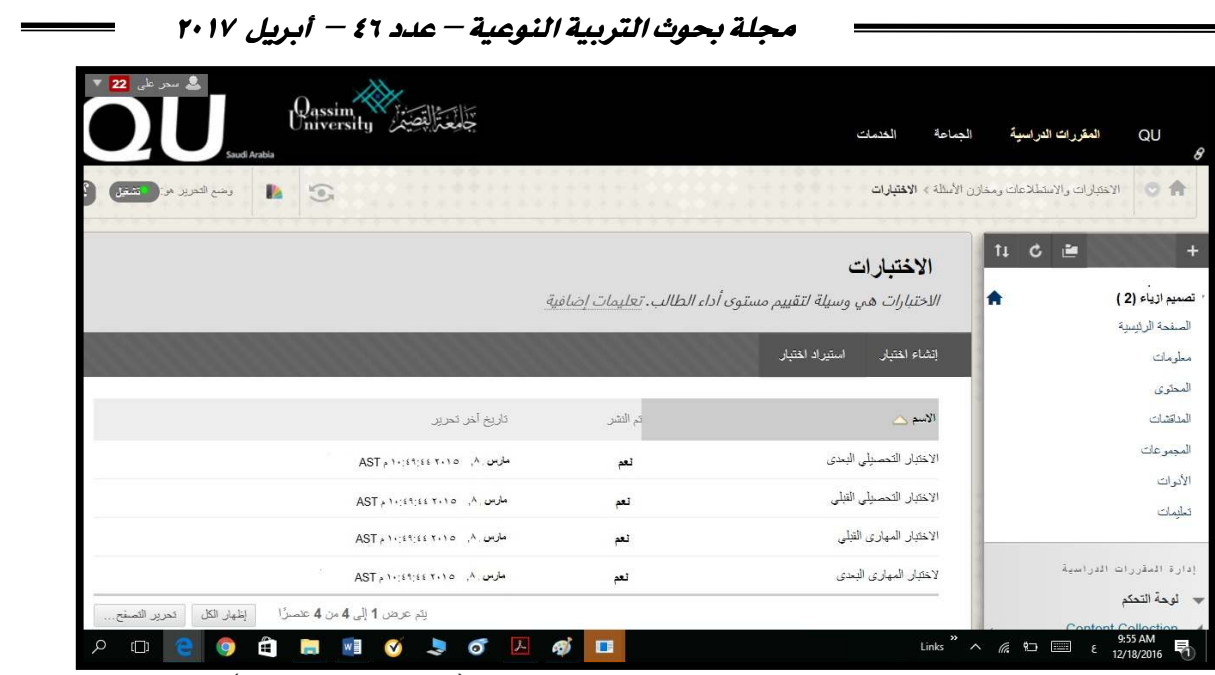

شاشه توضح الإختبارات التحصيليه المعرفيه والمهاريه ( القبليه / البعديه )

شكل ( )

• ضبط وتقويم الوحدة : بعد الإنتهاء من إعداد الوحدة الإلكترونيه بنظام "البلاك بورد " ملحق

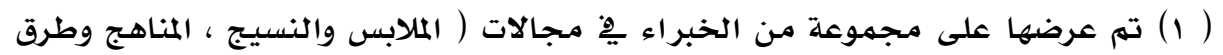

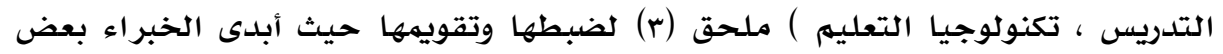

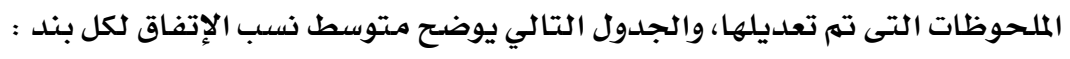

$$
\text { جدول (r) }
$$

متوسط نسب الاتفاق بين آراء الخبراء على بنود تحكيم وحدة من مقرر تصميم أزياء ( r ) بنظام البلاك بورد

\begin{tabular}{|c|c|c|}
\hline نسب الاتفاق & 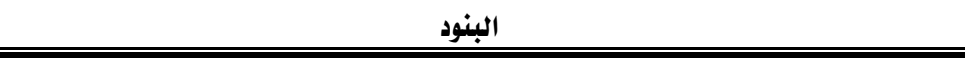 & 今 \\
\hline$\% 99$ & ملائهه الصوره الخاصه بالوحده (Banner ) وإرتباطها بالمحتوى & 1 \\
\hline$\% 9 r$ & ملاءمه تنظيه المواد التعليميه وتسلسلها بطريقه تساعد الطالبات على سهوله تتبع محتويات الوحده & r \\
\hline$\%$ & توفر مواد تعليميه للطباعه داخل البلاك بورد (PDF ، Word) & r \\
\hline$\% 91$ & توفر مقاطع فيديو يمكن تعميلها & $\varepsilon$ \\
\hline$\% 90$ & ملائمه الرسوم التوضيحيه من حيث الوضوح & 0 \\
\hline$\% 99$ & ملائمه نوع وحجم الخط المستخدم في المحتوى النظرى والتطبيقي في نظام البلاك بورد & 1 \\
\hline$\% 99$ & صحة الأهداف الإجرائيه ( ترابطها وتنوعها وإمكانية قياسها ) & $\checkmark$ \\
\hline$\% 99$ & ارتباط المحتوي النظري والتطبيقي بالأهداف المراد تحقيقها & A \\
\hline$\%$ & التوظيف الأمثل للوسائل التعليمية في البلاك بورد من أشكال توضيحية وبيان عملي & 9 \\
\hline$\% 9 v$ & ملاكمة طرق التدريس للمحتوي وترابطها مع الأهداف المراد تحقيقها & $1 \cdot$ \\
\hline$\% 99$ & تنوع الأنشطة التعليمية بما يجعل الطالبات أكثر فاعليه & 11 \\
\hline$\% 91$ & شمول التقويم للأهداف المراد قياسها & ir \\
\hline
\end{tabular}




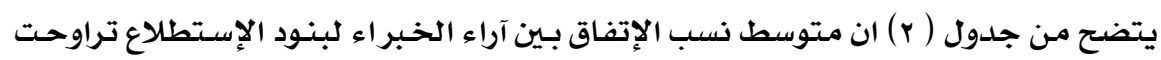

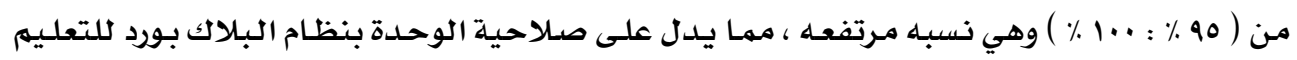

\section{r. خطوات بناء أدوات تقويم الوحلدة المقترحه :}

أ- بناء الإختبار التحصيلي المعريف ملحق (ع) : بهدف قياس مستوى الكفايات التى حققتها

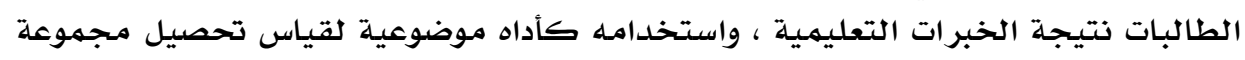

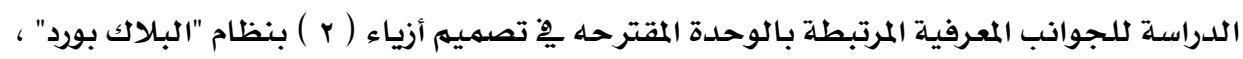

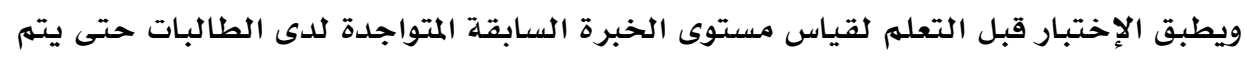

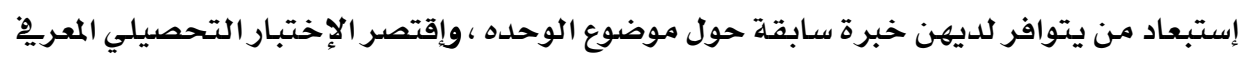

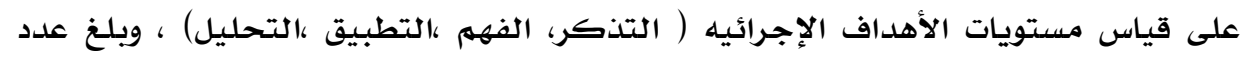

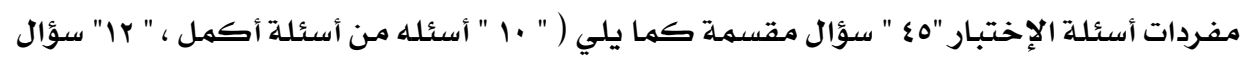

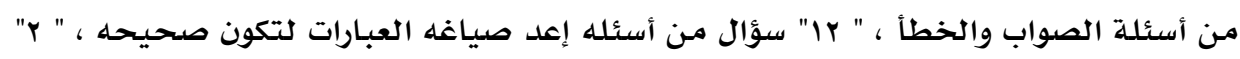

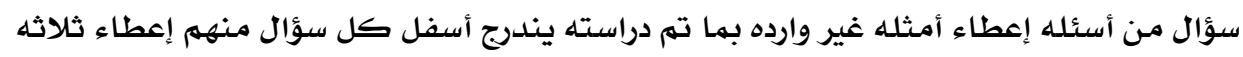

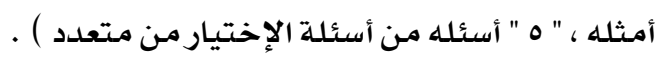

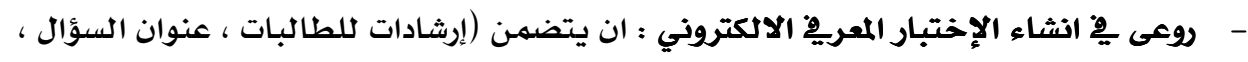

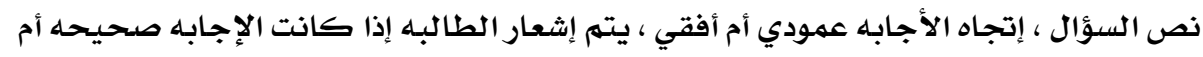

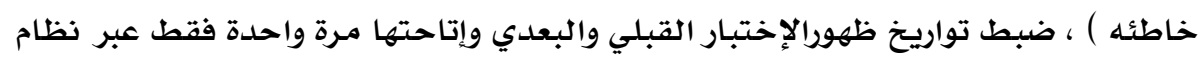

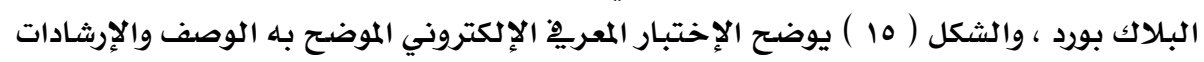

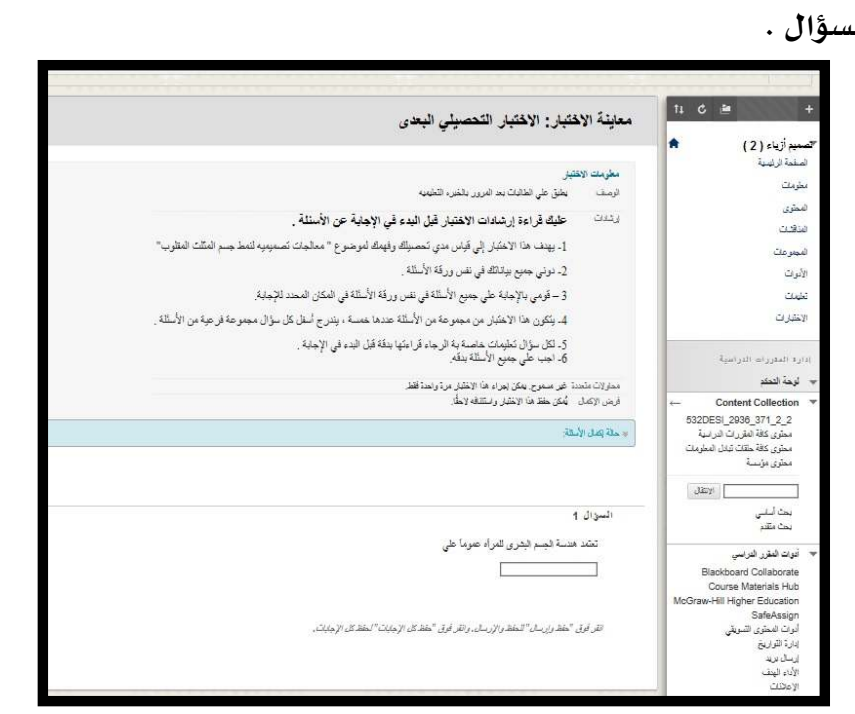

شاشه توضح الإختبار المعريِ موضح به الوصف والارشادات ونص السؤال شكل (10) 
- جدول مواصفات الإختبار : يقصد بة (الأسس التي بني عليها الإختبار ، نواتج التعلهم التي

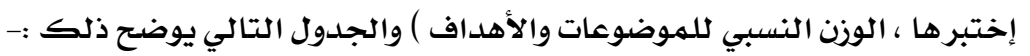

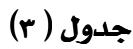

جدول المواصفات ( الأوزان النسبية للإختبار المعريو )

\begin{tabular}{|c|c|c|c|c|c|}
\hline 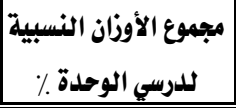 & ت تحليل & تطبيق & فهم & تذكر & الأهداف المعرفية \\
\hline$\xi r, r$ & - & - & 11,1 & rI, & الجسرس الأول : تشريح جسم المرأه والتطـور التـاريخي لانعاطهـا \\
\hline or, $A$ & $\|, r$ & Ir, & 10,0 & IV, & المعالجه التصميمه لنمط الجسيم المثلث المقلوب . التقسيم الحسيث للانهـاط الجسميه للمـرأه ، \\
\hline $1 \ldots$ & $11, r$ & $\mid r, \xi$ & $r q, 7$ & $\{\Lambda, \Lambda$ & المجموع \\
\hline
\end{tabular}

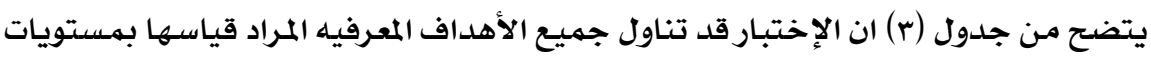

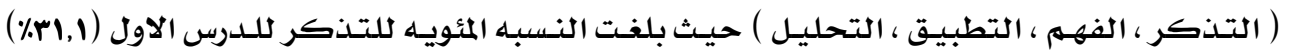

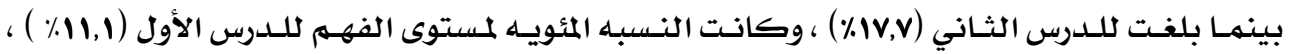

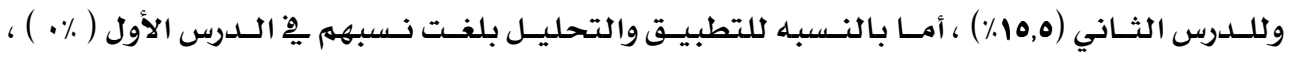

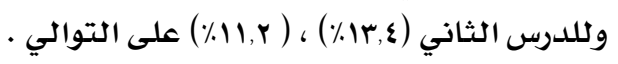

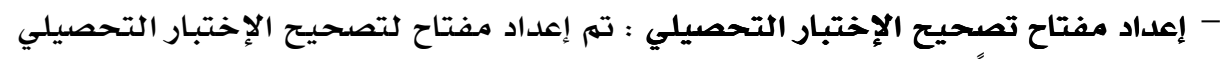

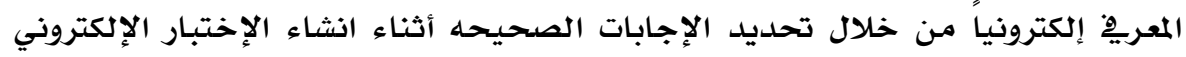

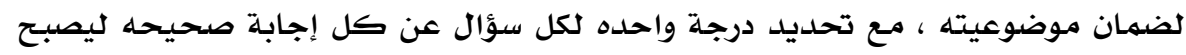

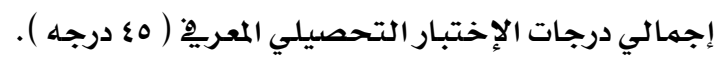

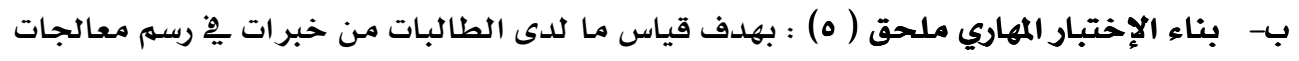

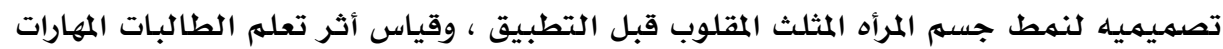

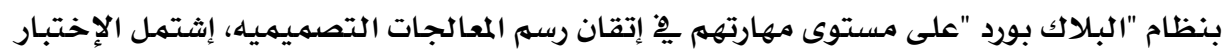

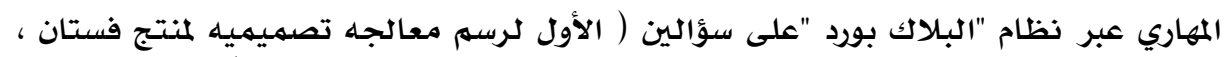

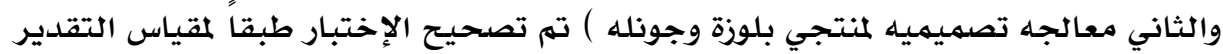

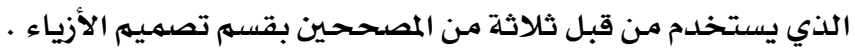

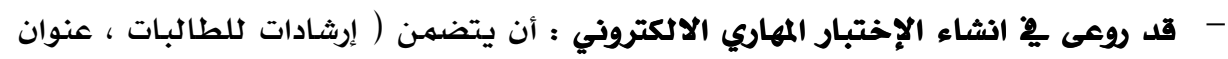

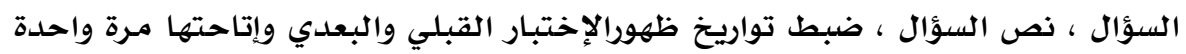

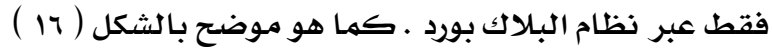




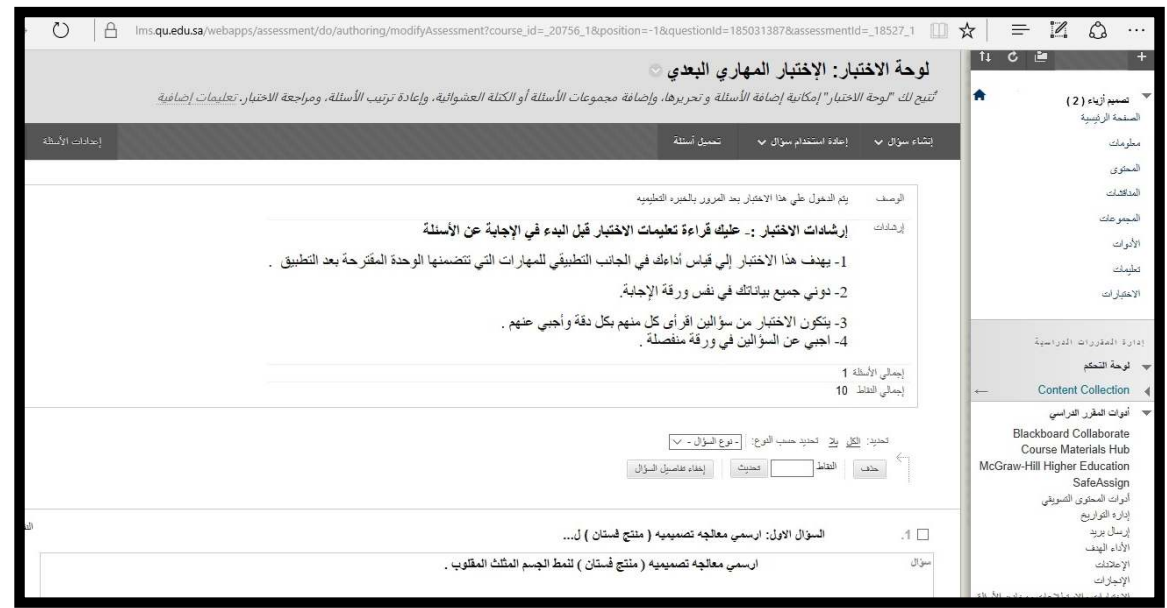

شاشه توضح الإختبار المهاري موضح بها الوصف والارشادات ونص السؤال

(19) ثكل

ج- بناء مقياس التقدير ملحق ( 7 ) : بهدف تقدير الأداء المهارى للطالبات يٍْ كل من التطبيق

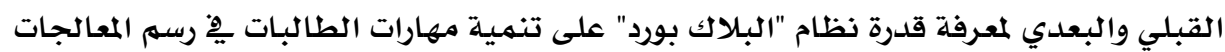

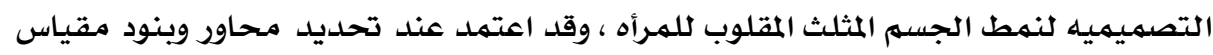
التقديرعلى تحليل أداء كل مهارة إلى مجموعة خطوات بسيطة تم صياغتها ِِّ عبارات

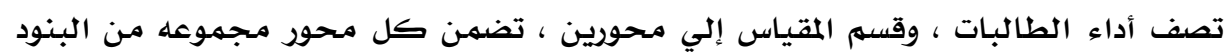

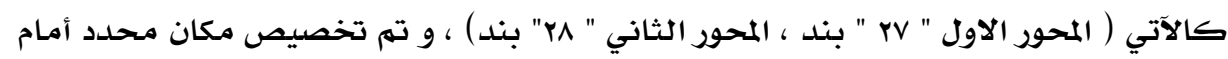

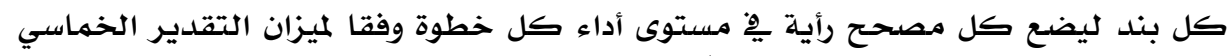

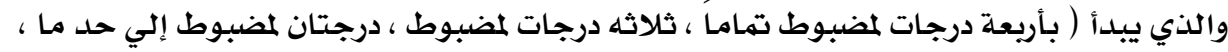

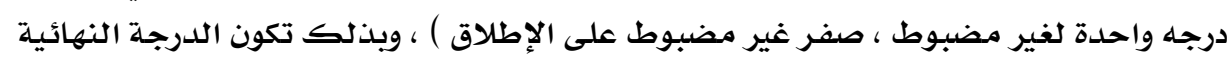

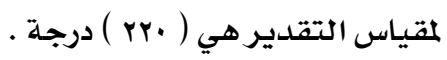

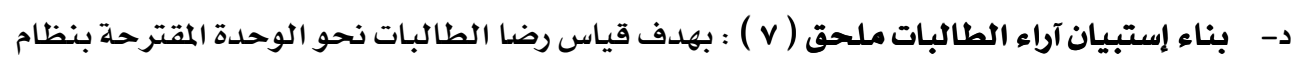

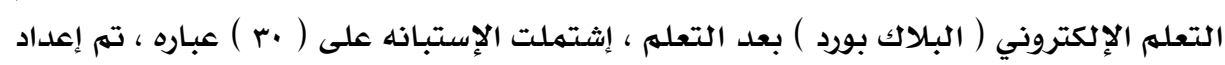

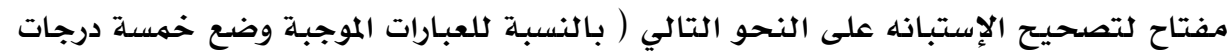

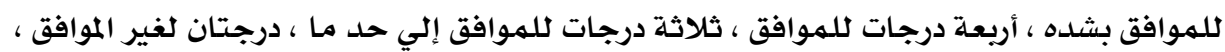

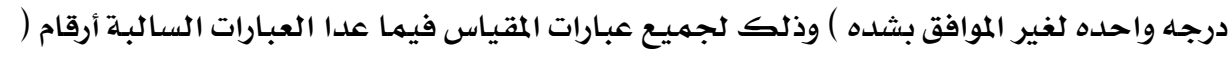

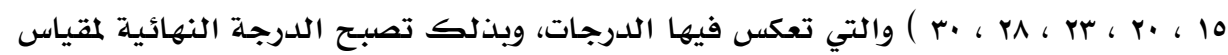

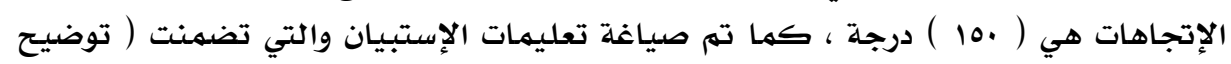

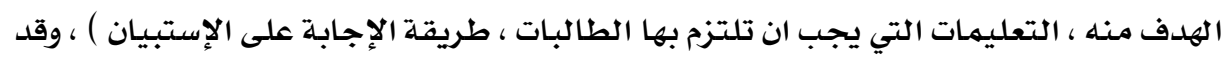
تم وضعها يِّ نفس ورقة الإستبيان. 
تم إجراء التجربة الإستطلاعية على عينه مكونه من ( . ) طالبات بهدف التأكد من وضوح

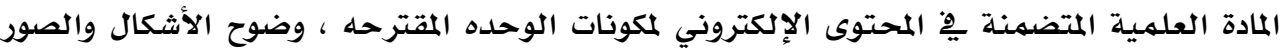

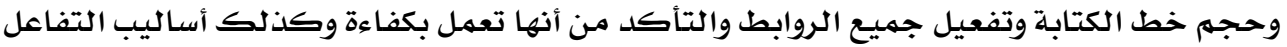

المبنية من خلال النظام ، التأكد من صدئ جدق وثبات الأدوات وحساب الزمن الكلازم لتطبيقها .

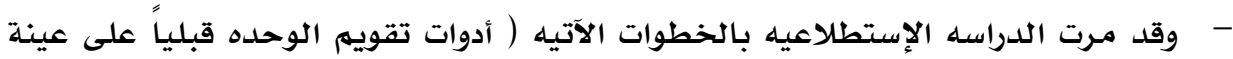

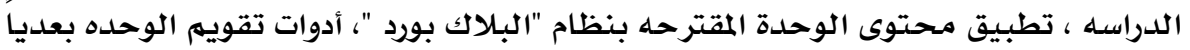

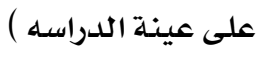

\section{ـ صدق وثبات أدوات تقويم الوحلدة :

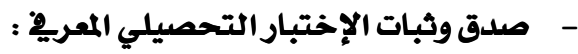

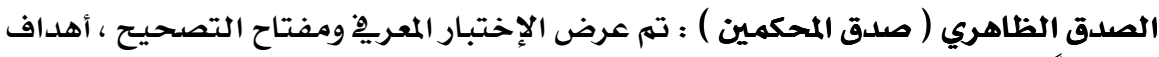

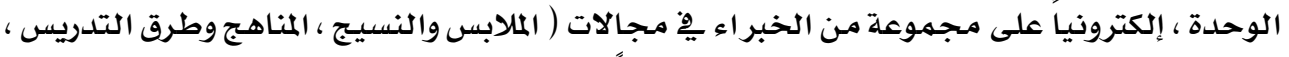

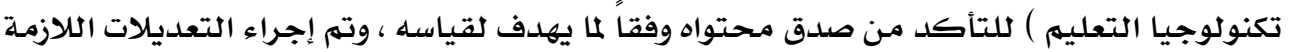

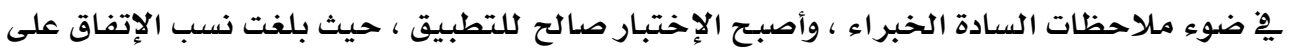

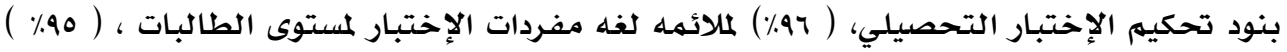

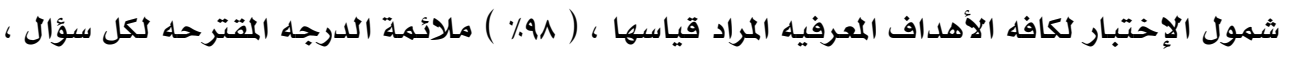
مما يدل على صدق الإختبار وصلاحيتة للتطبيق. ثبات الإختبار التحصيلي المعربِ : تم حساب معامل ثبات الإختبار ألتحصيلي المعريِ

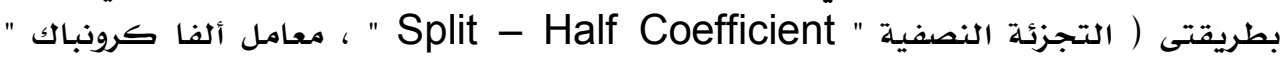
الاحمئ Cranbach's Alpha

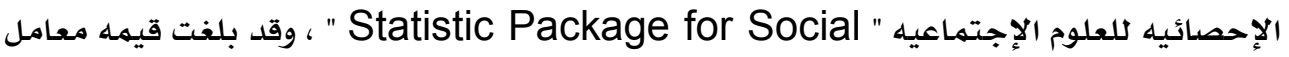

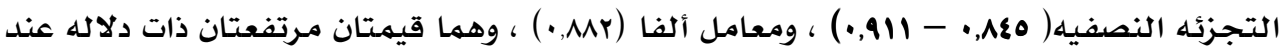

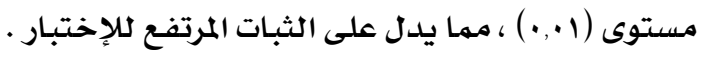

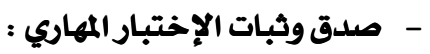

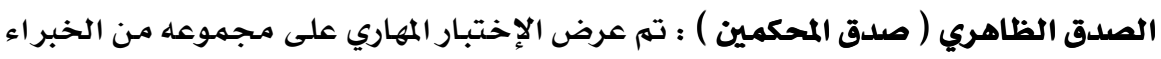

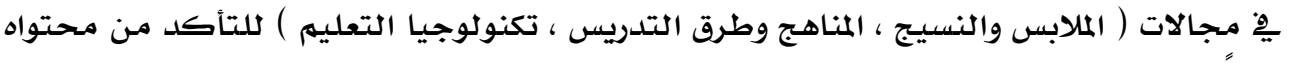

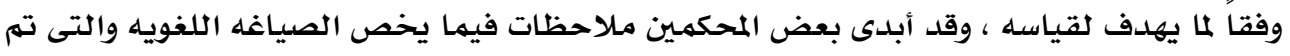

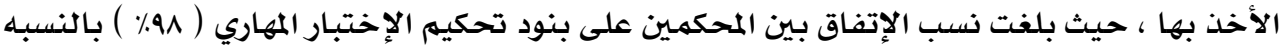

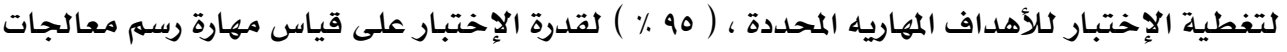

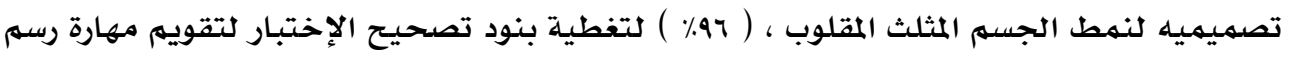


معالجات تصميميه لنمط الجسم المثلث المقلوب ، ( 90 ٪ ) لدقة صياغة عبارات أسئله الإختبار ، وهي نسب مـرتفغه مها يـل على صدق الإختبار المهاري وصلاحيته للتطبيق . ثبات الإختبار ألمهاري : تم حساب ثبات الإختبار المهاري عن طريق ثبات المصححـين، بحساب معامل الإرتباط بين الدرجات التى يعطيها مصحححان أو أكثر لنفس أفراد العينـه ،والجـدول التالي يوضتح معامل إرتباط الرتب بين درجات مصححي الإختبـار المهاري (س، ص، ع) :

\section{جدول رقم (ع)}

قيم معاملات الارتباط بين درجات مصححي الإختبار المهاري

\begin{tabular}{|c|c|c|}
\hline الثاني & الأول & السـؤال \\
\hline$\cdot, 9$. & $\cdot, 91$ & س ، ص \\
\hline$\cdot, 90$ & $\cdot, \wedge \mathrm{V}$ & س ، ع \\
\hline •, 94 & $\cdot, \wedge 9$ & ص ، ع \\
\hline
\end{tabular}

يتضح مـن الجدول ( ع ) إرتفاع قيهم معاملات الإرتباط بين درجات المصححين ، حيث تراوحت من (AV) • - 9 9, • ) مها يدل على ثبات الإختبار المهاري ومقياس التقدير الذي أستخدم لتقويهم أداء

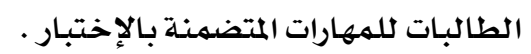
- - ملدق وثبات مقياس التقدير : الصلدق الظاهري ( صلدق المحكمين ) : تم عرض مقياس التقدير على مجمموعة مـن الخبر اء

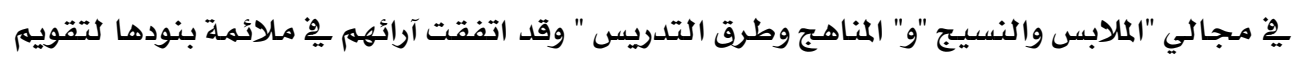
الأداء المهاري للطالبات ، كما تم الأخذ بالملاحظات التي أبداها الخبر اء فيما يخص الصياغه اللغويه ، وبلغت نسب الاتفاق بين الخبر اء على بنود تحكيه مقياس التقدير (90٪) لصححة صياغه محاور

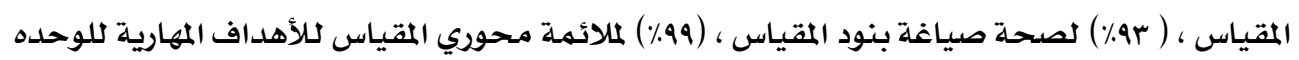

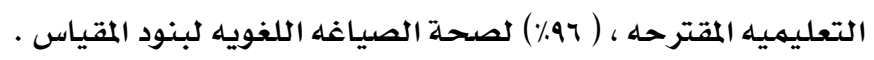
ثبـات مقيـاس التقدير : تم التأكد مـن ثباته عن طريـق حسـاب معامل الإرتبـاط بـين

درجات المصححين كما سبق ذكره يِ الإختبار المهاري . - هدق وثبات إستبيان إستطلاع رضا الطالبات : تم التأكد من صدق الإستبيان عن طريق (الصدق الظاهرى " صدق المحكمـين" ، الصدق باستخدام الاتسـاق الداخلي بين درجة كل عبارة والدرجـة الكلية كلإستبيان) وفيما يلي توضيح ذلك:-

الصلدق الظاهري ( صلدق المحكمين ) : تم عرض الأستبيان على مجموعة من الخبر اء يِ مـجالي "الملابس والنسيـج "و" المناهـج وطرق التدريس " للتأكد من محتواه وفقا لما يهدف لقياسـة وقد

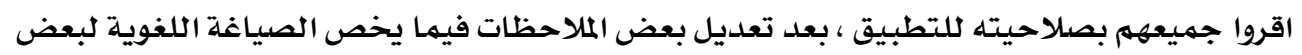


العبارات وإضافة بعض العبارات الآخرى ، حيث بلغت نسب إتفاق الخبر اء حول بنود تحكيم الاستبيان

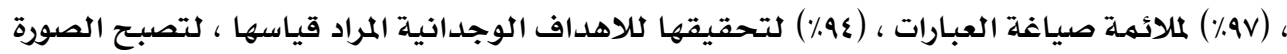

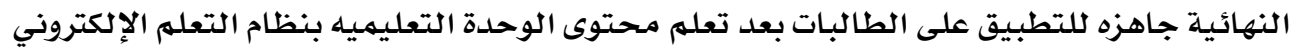

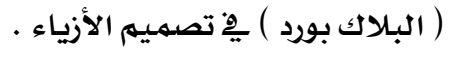

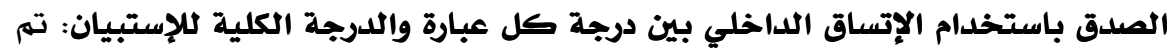

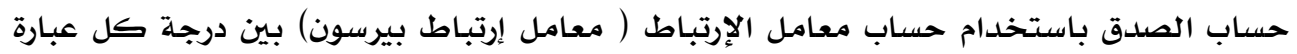

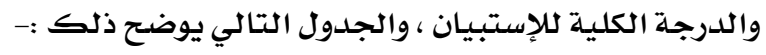

جدول (0)

قيم معاملات الارتباط بين كل عبارة والدرجة الكلية لإستبيان رضا الطالبات

\begin{tabular}{|c|c|c|c|c|c|c|c|c|}
\hline الدلالة & الارتباط & $\hat{n}$ & الدلالة & الارتباط & 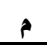 & الدلالة & الارتباط & م \\
\hline$\cdot,+1$ & $\cdot, \wedge 91$ & rI & $\cdot,+1$ & - Arr & 11 & $\cdot,+1$ & $\cdot, 190$ & 1 \\
\hline$\cdot,+1$ & •,941 & rr & $\cdot,+1$ & -, ATE & ir & $\cdot, \cdot 1$ & $\cdot, 911$ & $r$ \\
\hline$\cdot, \cdot 1$ & $\cdot, \mathrm{\wedge}$. & rr & $\cdot, \cdot 1$ & -, $\vee 99$ & ir & $\cdot, \cdot 1$ & •, V\I & $r$ \\
\hline$\cdot, \cdot 1$ & $\cdot, 91$. & YE & $\cdot, \cdot 1$ & •, АTร & $1 \varepsilon$ & $\cdot, \cdot 1$ & , $\vee \wedge \wedge$ & $\varepsilon$ \\
\hline$\cdot, \cdot 1$ & •, vir & ro & $\cdot, \cdot 0$ & •, ๆะ• & 10 & $\cdot, \cdot 1$ & 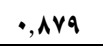 & 0 \\
\hline$\cdot, \cdot 1$ & - $\mathrm{YAI}$ & $r y$ & $\cdot, \cdot 1$ & -, 199 & 17 & $\cdot, \cdot 1$ & $\cdot, 911$ & 7 \\
\hline$\cdot, \cdot 1$ & $\cdot, \wedge$. & rV & $\cdot, \cdot 1$ & $\cdot, 91$. & iv & $\cdot, \cdot 1$ & - AVY & r \\
\hline$\cdot, \cdot 1$ & •, AVr & rA & $\cdot, \cdot 1$ & •, マYๆ. & 11 & $\cdot, \cdot 1$ & $\cdot 91$. & $\wedge$ \\
\hline$\cdot,+1$ & $\cdot, \wedge \wedge \wedge$ & rq & $\cdot, \cdot 1$ & $\cdot, \wedge 99$ & 19 & $\cdot, \cdot 1$ & $\cdot, 100$ & 9 \\
\hline$\cdot, \cdot 0$ & $\cdot, 797$ & $r \cdot$ & $\cdot, \cdot 1$ & $\cdot, \wedge 97$ & r. & $\cdot, \cdot 1$ & -, $\vee 99$ & 1. \\
\hline
\end{tabular}

يتضح من الجدول ( 0 ) ان معاملات الارتباط كلها دالة عند مستوى ( 1... ) لإقترابها مـن

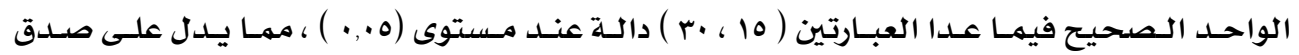
وتجانس عبارات الإستبيان .

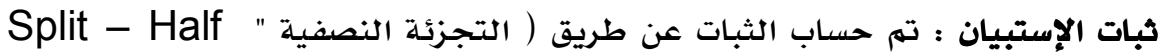

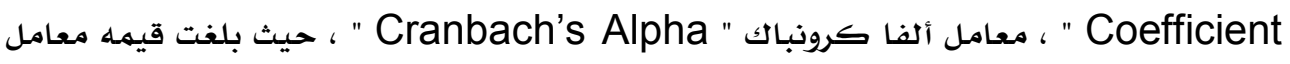

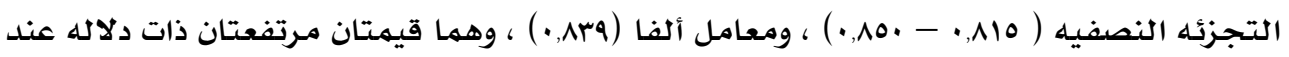

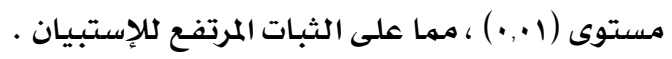
تحديد زمن الأجابه على كل من ( الإختبار التحصيلي المعريف ، الإختبار المهارى ، إستبيان رضا الطالبات ) : (9)

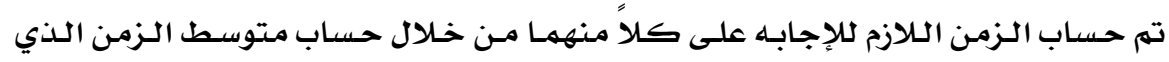

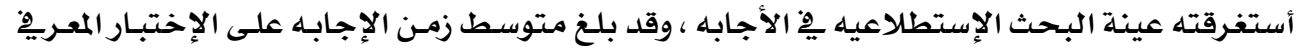

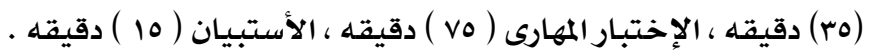


أهداف الدراسه الأساسيه : تحديد فاعلية وحلده تعليميه بنظام التعلهم الألكتروني (البلاكك

$$
\text { بورد) يِّ تصميم أزياء النساء وقد مرت التجريـة بالمراحل الآتية : }
$$

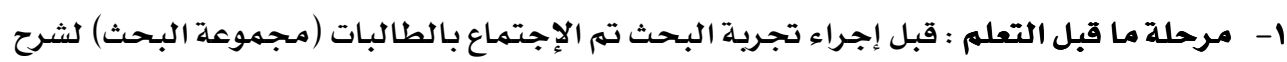

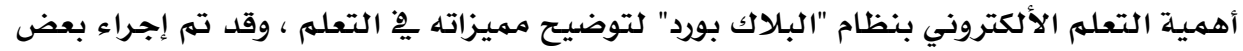

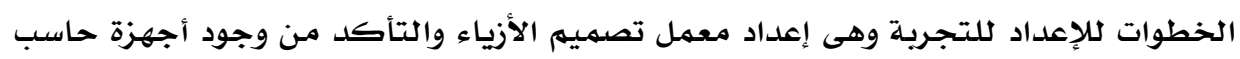

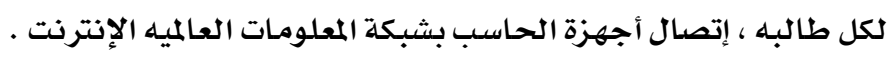

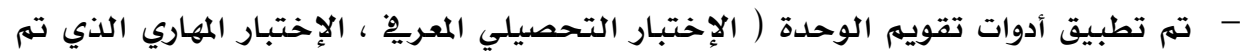

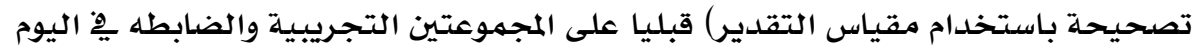

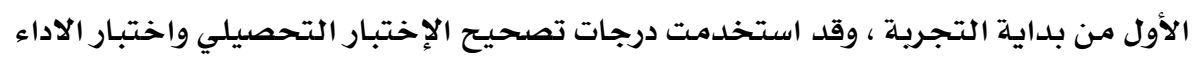

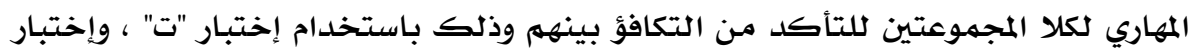

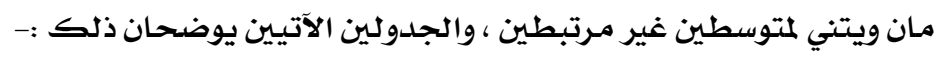

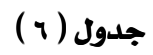

دلالة الفروق بين متوسطي درجات الطالبات بالمجموعتين الضابطة و التجريبية يِ التطبيق القبلي للاختبار

\begin{tabular}{|c|c|c|c|c|c|c|c|c|c|}
\hline الدلالة & $\begin{array}{c}\text { Mann } \\
\text { Whitney }\end{array}$ & ماتلولي الدالة & قيمة ت & 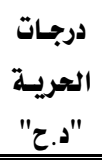 & الانحراف & الحتوسط & العداد & المجموعات & الاختبار \\
\hline \multirow{2}{*}{ غير دار } & \multirow{2}{*}{ •, Iro } & \multirow{2}{*}{ غير دال } & \multirow{2}{*}{$\cdot, \cdot r Y$} & \multirow{2}{*}{ ro } & 1,110 & 1, Yo. & ir & قبلي ضابطه & \multirow{2}{*}{ المحور الأول } \\
\hline & & & & & $1, \xi T r$ & 1,Vrr & 10 & قبلي تجريبيه & \\
\hline \multirow{2}{*}{ غير دال } & \multirow{2}{*}{$\cdot, 770$} & \multirow{2}{*}{ غير دال } & \multirow{2}{*}{$1, r V r$} & \multirow{2}{*}{ ro } & r,Yrs & 1,817 & ir & قبلي ضابطه & \multirow{2}{*}{ لمحور الثاني } \\
\hline & & & & & $\cdot, \mathrm{V91}$ & r, Y97 & 10 & قبلي تجريبيه & \\
\hline \multirow{2}{*}{ غير دال } & \multirow{2}{*}{ •, OOY } & \multirow{2}{*}{ غير دال } & \multirow{2}{*}{ •, हVr } & \multirow{2}{*}{ ro } & I,Av & $\{, r T$ & ir & قبلي ضابطه & \multirow{2}{*}{ المجموع } \\
\hline & & & & & 1,Yrr & $\varepsilon$ & 10 & قبلي تجريبيه & \\
\hline
\end{tabular}
التحصيلي المعربو

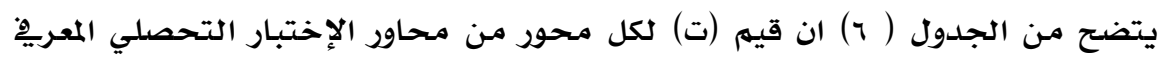

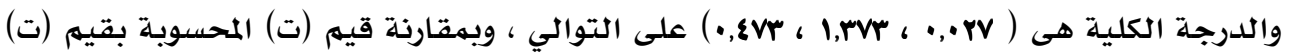

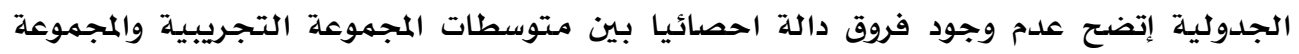

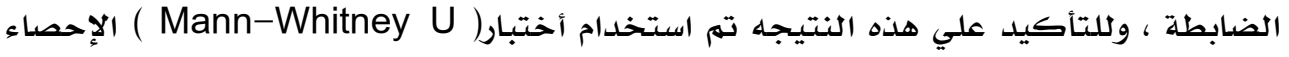

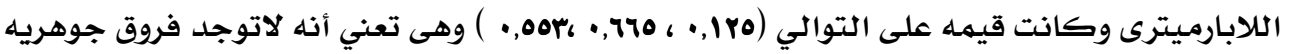

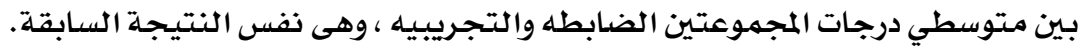


مجلة بحوث التربية النوعية - علد rأ - أبريل r.lV

جدول (v) (مات )

دلالة الفروق بين متوسطي درجات الطالبات بالمجموعتين الضابطه و التجريبيه

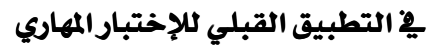

\begin{tabular}{|c|c|c|c|c|c|c|c|c|c|}
\hline الدلالة & $\begin{array}{c}\text { Mann } \\
\text { Whitney }\end{array}$ & ماتجتوى الدلاكة & قيمة ت & الدرجـــــــ & الالمعياري & الحسابي & العلد & المجموعات & الإخهبار \\
\hline \multirow{2}{*}{ غير دال } & \multirow[t]{2}{*}{ •, 1\$9 } & \multirow{2}{*}{ غير دال } & \multirow[t]{2}{*}{$1, \times 9$} & \multirow[t]{2}{*}{ ro } & $r, \wedge \varepsilon$ & $0, \bullet 1$ & ir & قبلي ضابطه & \multirow[t]{2}{*}{ المحور الأول } \\
\hline & & & & & $r, 0 \varepsilon$ & $0, r V$ & 10 & قبلي تجريبيه & \\
\hline \multirow{2}{*}{ غير دال, } & \multirow[t]{2}{*}{ •, หฯ. } & \multirow{2}{*}{ غير دال } & \multirow[t]{2}{*}{$\cdot, 09}$. & \multirow[t]{2}{*}{ ro } & $r, r r$ & 1,817 & ir & قبلي ضابطه & \multirow[t]{2}{*}{ لمحور الثاني } \\
\hline & & & & & $r, r A$ & $1,9 r$ & 10 & قبلي تجريبيه & \\
\hline \multirow{2}{*}{ غير دال } & \multirow[t]{2}{*}{ •,YIE } & •, 970 & \multirow[t]{2}{*}{ •, ITA } & \multirow[t]{2}{*}{ ro } & $\xi, r \mu$ & 7,7 & ir & قبلي ضابطه & \multirow[t]{2}{*}{ المجموع } \\
\hline & & غير دال & & & $\xi, \cdot r$ & $r, r$ & 10 & قبلي تجريبيه & \\
\hline
\end{tabular}

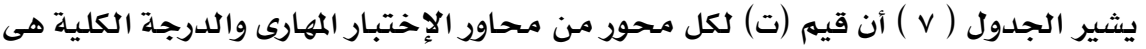

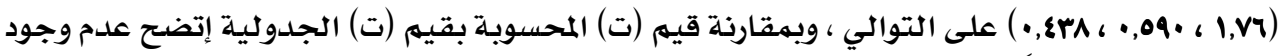

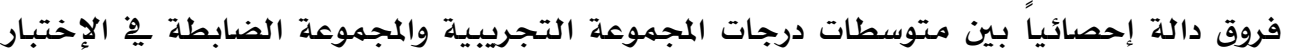

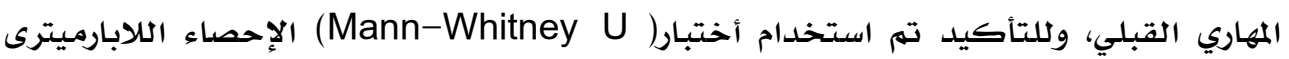

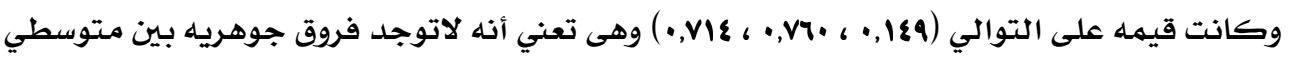

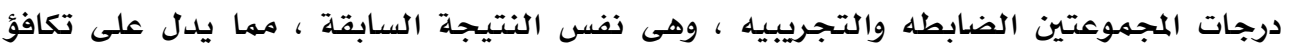
المجموعتين المرجات

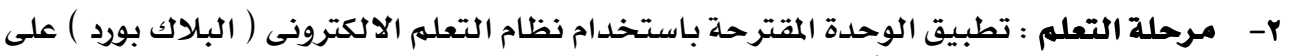

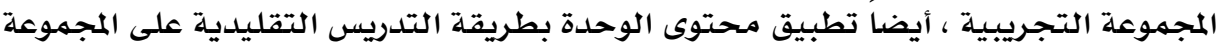

الضابطة .

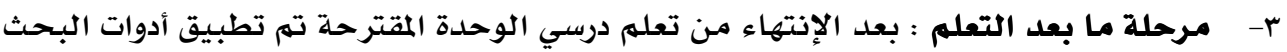

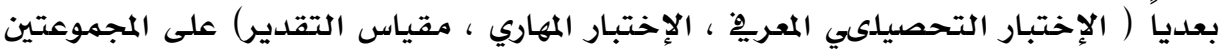

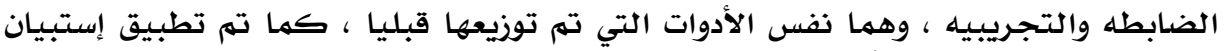

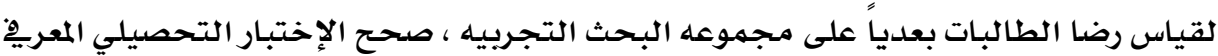

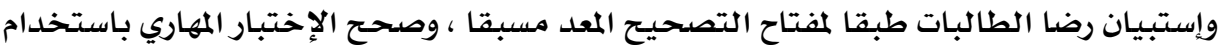

$$
\text { مقياس التقدير • وفيسان }
$$

\section{نتائج البحث تعليلها وتفسيرها:}

حللت الباحثة البيانات المستخرجة من واقع درجات عينة البحث (المجموعتين التجريبية

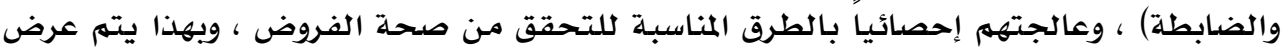

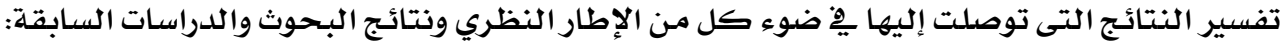




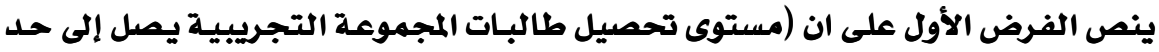

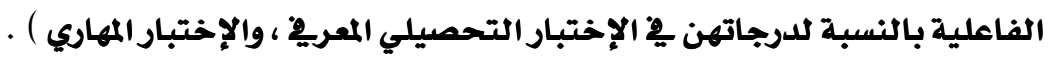

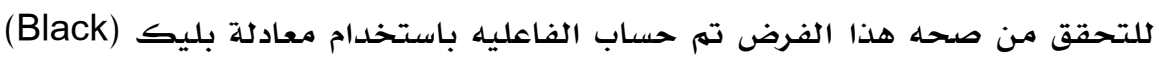

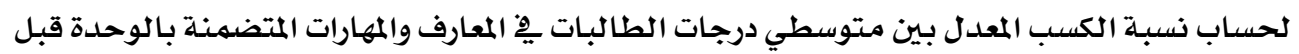

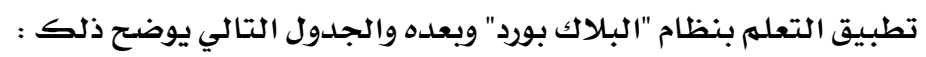

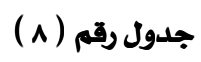

نسبة الكسب المعدل بين متوسطي درجات الطالبات فِ المعارف والمهارات المتضمنة بالوحدة

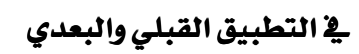

\begin{tabular}{|c|c|c|c|c|}
\hline الفاعلىه & نسبه الكسب & المتوسط الحسابي & التطبيق & الإختبار \\
\hline \multirow{2}{*}{ يوجد فاعلية } & \multirow{2}{*}{1,97} & $\varepsilon$ & قبلي & \multirow{2}{*}{ التحصيلي / معرفي } \\
\hline & & $\{r, 7 \uparrow$ & بعدي & \\
\hline \multirow{2}{*}{ يوجد فاعلية } & \multirow{2}{*}{1,97} & $v, r$ & قبلي & \multirow{2}{*}{ المهاري } \\
\hline & & rir, & بعلى ب ل بع & \\
\hline
\end{tabular}

يتضح من الجدول ( ^) ان نسبة الكسب المعدل للمجموعة التجريبية ِِو الإختبار

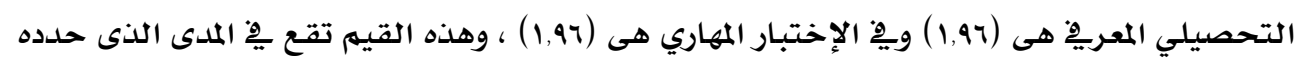

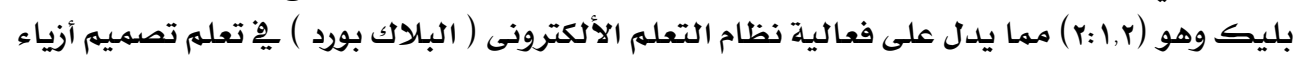
النسـاء.

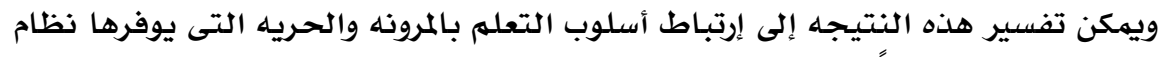

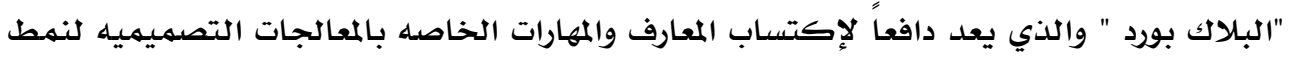

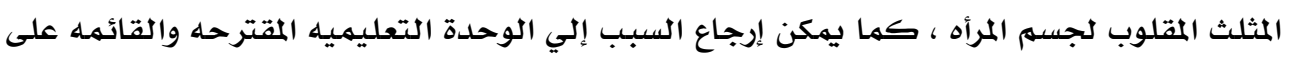

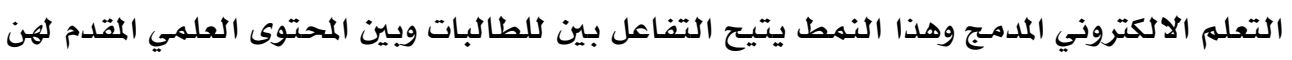

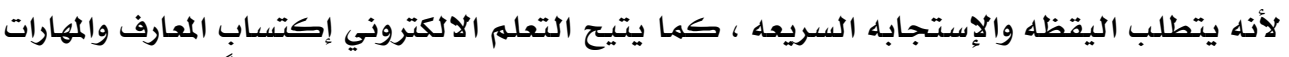

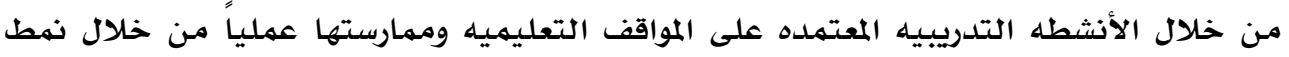

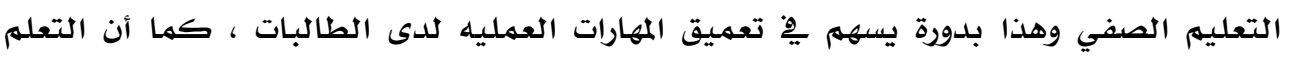

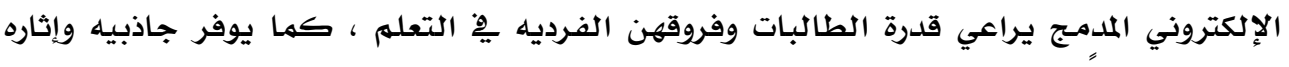

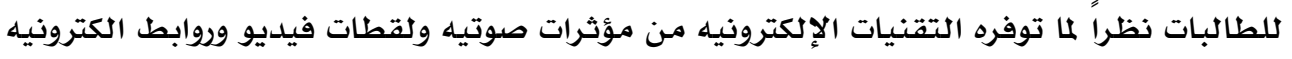

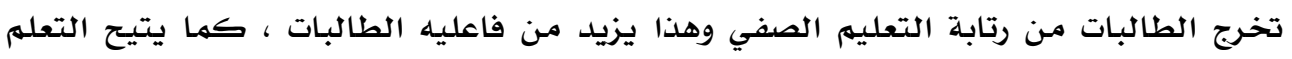

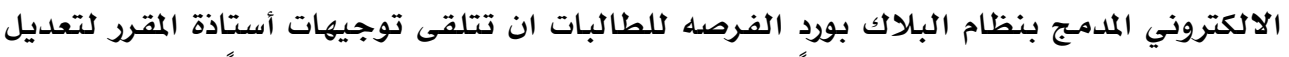

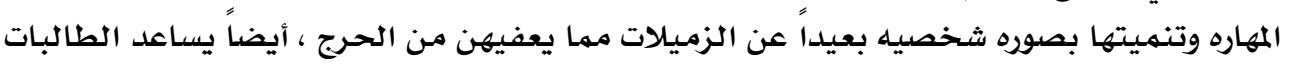

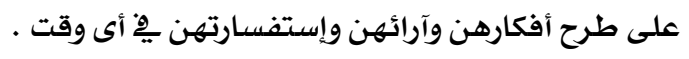




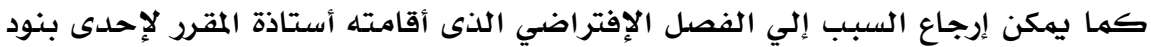

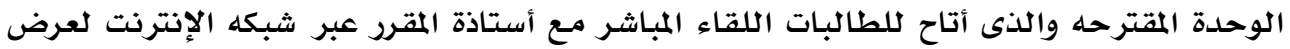

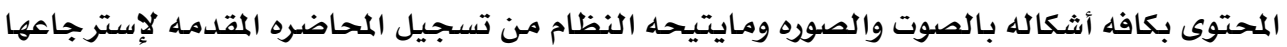

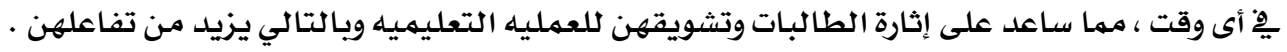
وتتفق هذة النتيجة مع دراسه دراسة (Servon sky \& others : 2005 ) التى التى

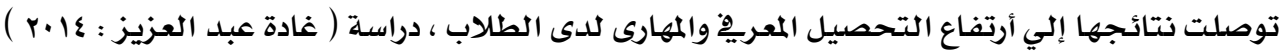

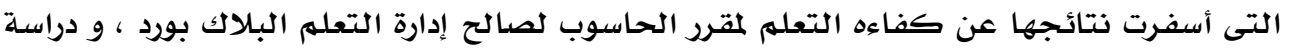

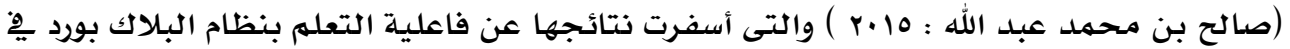

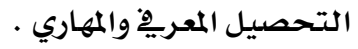

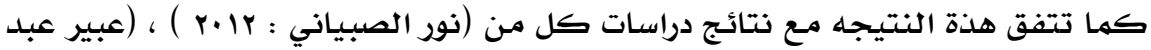

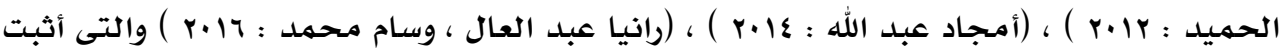

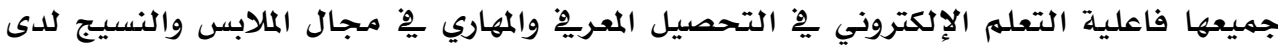

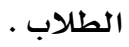

ينص الفرض الثانى على أنه " توجد فروق دالـة إحصائياً بـين متوسطي درجـات طالبـات

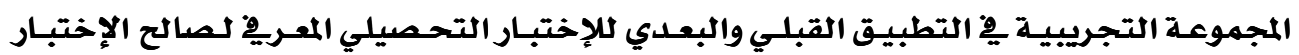

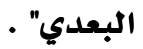

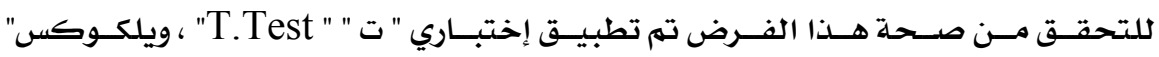

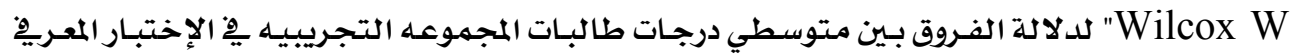

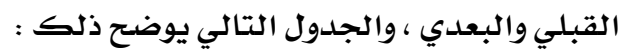

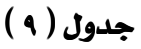

دلادة الفروق بين متوسطي درجات الطالبات بالمجموعة التجريبيه هِّ التطبيق القبلي والبعدي للإختبار التحصيلي المعريٌ ( ن =0 10 )

\begin{tabular}{|c|c|c|c|c|c|c|c|c|}
\hline الدلاله & $\begin{array}{c}\text { Wilcox } \\
\text { W }\end{array}$ & والدالالة & قيمة & "درجــات & الانحراف & الحسابي & التطبيق & الإختبار \\
\hline \multirow{2}{*}{ 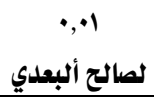 } & \multirow[t]{2}{*}{ r,IYr } & \multirow{2}{*}{ لصالح ألبعدي } & \multirow[t]{2}{*}{$r q, \Lambda$} & \multirow[t]{2}{*}{$1 \xi$} & 1,\&rV & $1, v \varepsilon$ & قبلي & \multirow[t]{2}{*}{ المحور الأول } \\
\hline & & & & & •, Vミr & IA, Ir & بعدي & \\
\hline \multirow{2}{*}{ لصالح ألبعدي } & \multirow[t]{2}{*}{$r,\{\eta\rceil$} & \multirow{2}{*}{ لصالح ألبعدي } & \multirow[t]{2}{*}{$9 r, Y$} & \multirow[t]{2}{*}{$1 \xi$} & •, $\vee 9$ & $r, r q$ & قبلي & \multirow[t]{2}{*}{ المحور الثاني } \\
\hline & & & & & $\cdot, 01$ & ro,or & بعدي & \\
\hline \multirow{2}{*}{ لصالح ألبعدي } & \multirow[t]{2}{*}{$r, \xi \mid \gamma$} & \multirow{2}{*}{ لصالح ألبعدي } & \multirow[t]{2}{*}{ Vr, rq } & \multirow[t]{2}{*}{$1 \xi$} & $1, v V$ & $\varepsilon$ & قبلي & \multirow{2}{*}{ الإختبار ككل مجموع } \\
\hline & & & & & 1,11 & 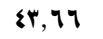 & بعدي & \\
\hline
\end{tabular}




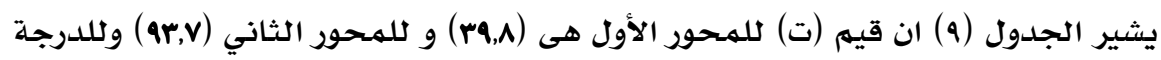

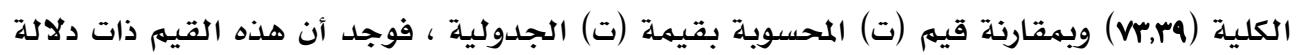

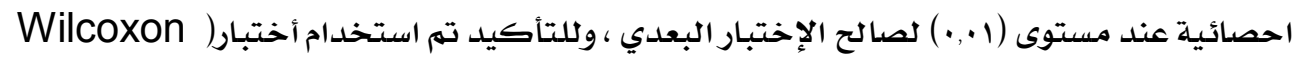

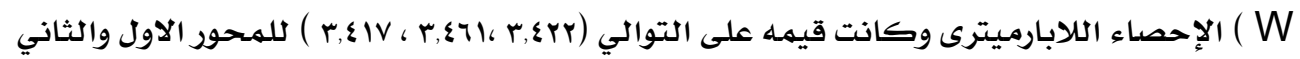

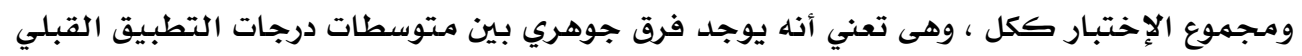

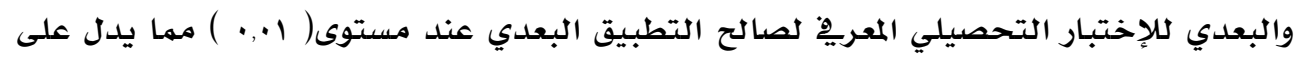

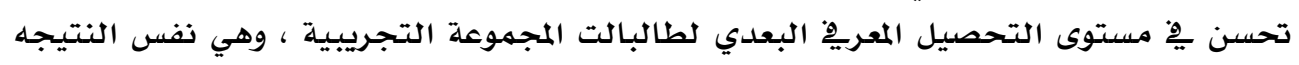
السـابقه . تحن

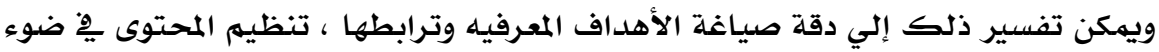

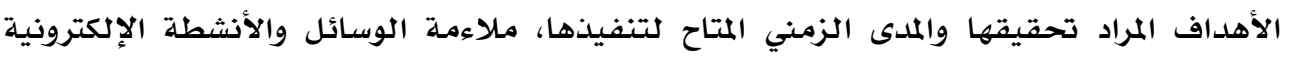

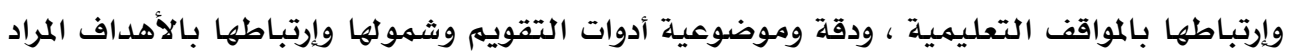

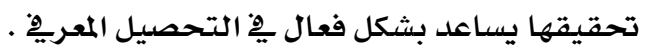

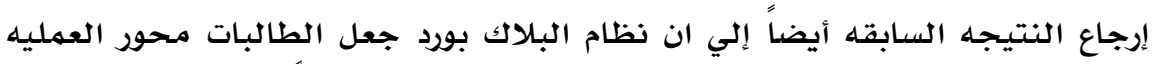

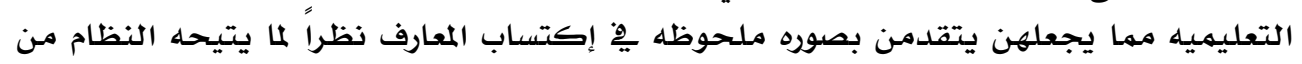

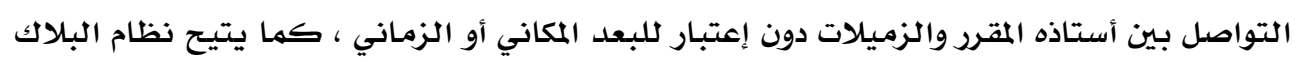

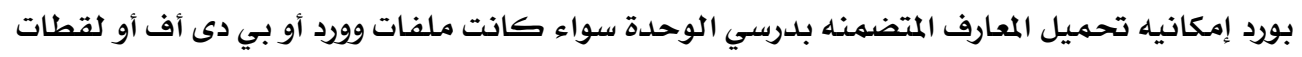

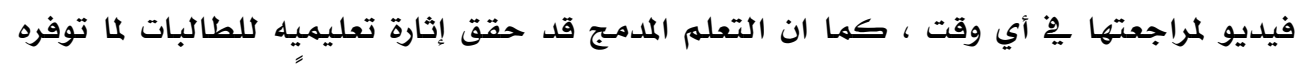

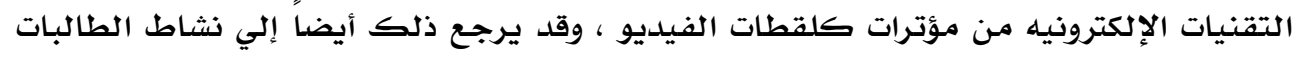

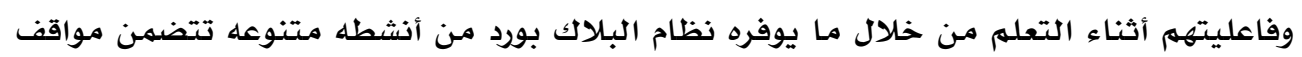
تعليميه متنوعه.

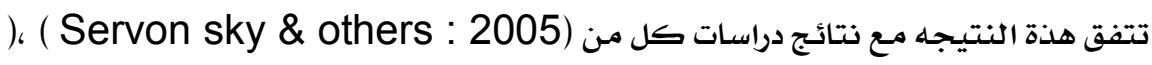

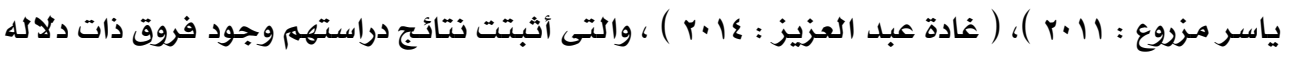

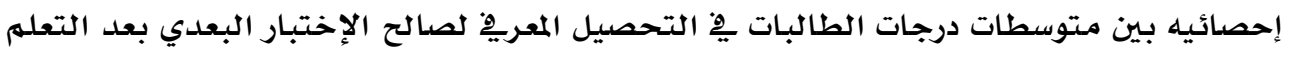

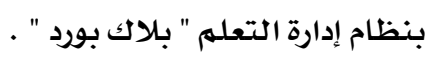

كما تتفق مع نتائج الدراسات التى أثبتت ان التعله الإلكتروني يحسن من التحصيل

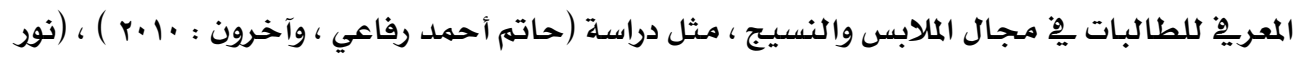

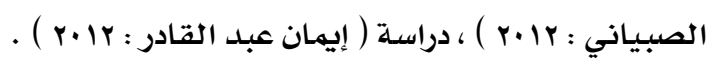

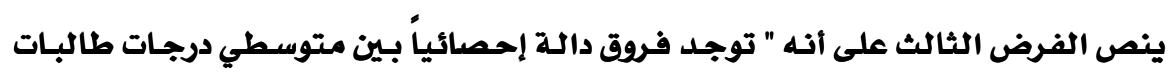

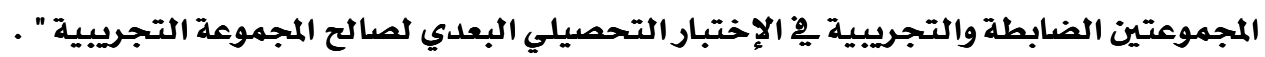

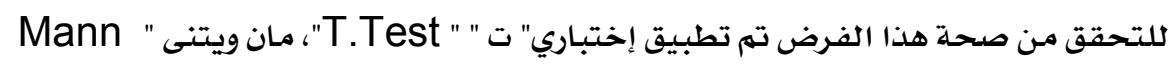

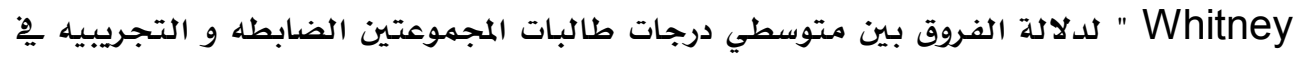

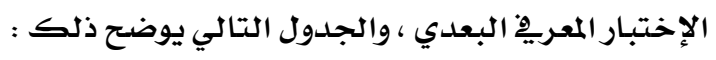




$$
\text { جدول (1.) (11) }
$$

دلالة الفروق بين متوسطي درجات الطالبات بالمجموعتين الضابطه و التجريبيه هِ التطبيق البعدي للإختبار التحصيلي المعربو

\begin{tabular}{|c|c|c|c|c|c|c|c|c|c|}
\hline الدلالة & \begin{tabular}{|c|} 
Mann \\
Whitney \\
\end{tabular} & مستوى الدلالة & |قيمة ت & العريـة "د.ـح" درجـات & المعياري "ع" & الحسابي "م" التوسط" & العدد & المجموعات & الإختبار المعرفي \\
\hline \multirow{2}{*}{ الترالتريبيه } & \multirow[t]{2}{*}{,$\xi 0 \gamma$} & \multirow{2}{*}{ التجريبيه } & \multirow[t]{2}{*}{$11, \cdot v$} & \multirow[t]{2}{*}{ ro } & I, \{ & Ir, IV & ir & بعدى ضابطه & \multirow[t]{2}{*}{ المحور الأول } \\
\hline & & & & & $\cdot, v \varepsilon$ & $1 \mathrm{~A}, \mathrm{IT}$ & 10 & بعدى تجريبيه & \\
\hline \multirow{2}{*}{ التجريبيه } & \multirow[t]{2}{*}{$\varepsilon$, rTo } & \multirow{2}{*}{ التجريبيه } & \multirow[t]{2}{*}{$0, r \cdot r$} & \multirow[t]{2}{*}{ ro } & $\{, 11$ & $19, \cdot 1$ & ir & بعدى ضابطه & \multirow[t]{2}{*}{ المحور الثاني } \\
\hline & & & & & $\cdot, 01$ & ro,or & 10 & بعدى تجريبيه & \\
\hline \multirow{2}{*}{ التجريبيه • لصالح } & \multirow[t]{2}{*}{ \&,ZTY } & \multirow{2}{*}{ التجريبيه • لصالح } & \multirow[t]{2}{*}{$9, Y \varepsilon$} & \multirow[t]{2}{*}{ ro } & $r, q r$ & rr, ro & ir & بعدى ضابطه & \multirow{2}{*}{ الإختبار المعرفي } \\
\hline & & & & & 1,11 & 84,74 & 10 & بعدى تجريبيه & \\
\hline
\end{tabular}

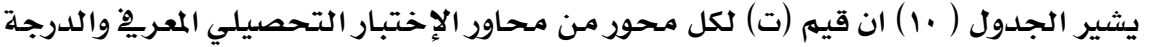

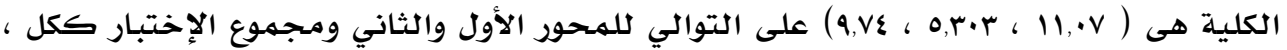

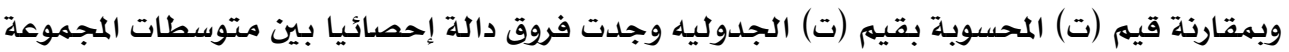

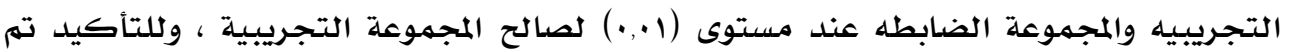

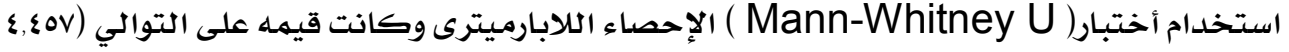

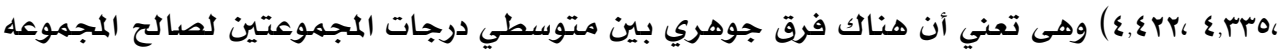

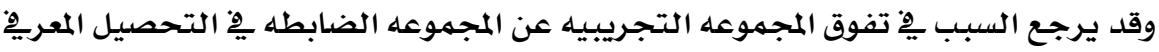

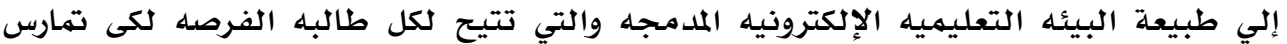

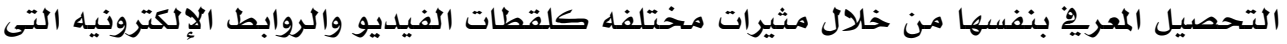

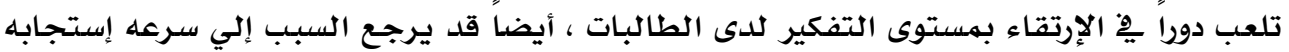

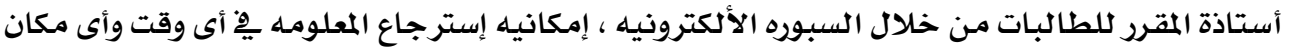

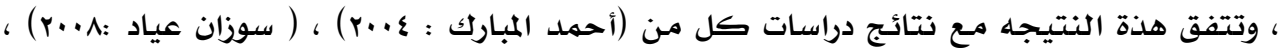

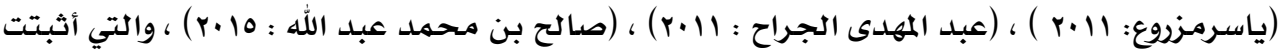

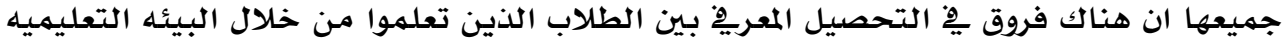

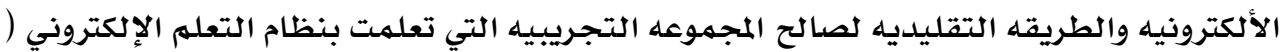

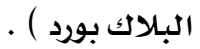

وهذا يتفق مع مـا أشاد به (Bonk,C \& Graham,J : 2005) ان التعلهم الإلكتروني

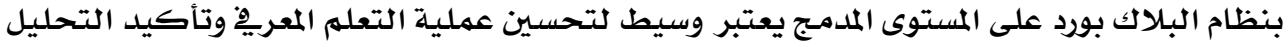

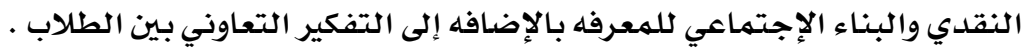


كما تتفق هذة النتيجه مـع نتائج الدراسات التى تناولت التعله الالكتروني ِِّ مجال

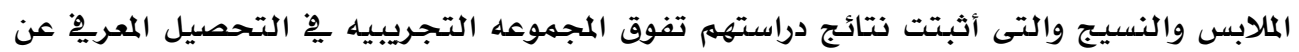

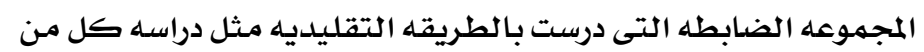

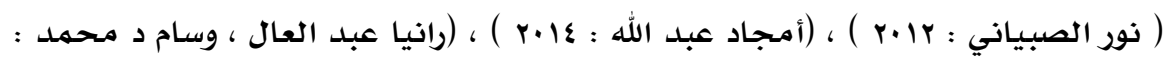

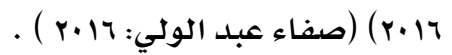

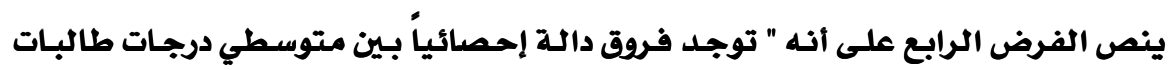

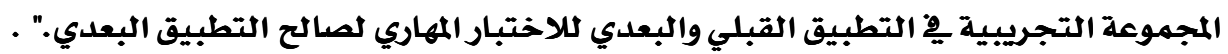

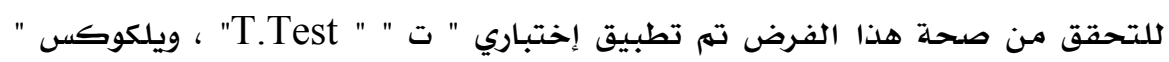

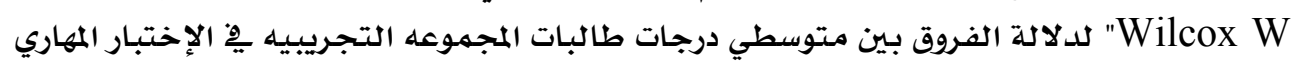
القبلي والبعدي ، والجدول التالي يوضـح ذلك الكرق دين متوسطي درجات

جدول (II)

دلالة الفروق بين متوسطي درجات الطالبات بالمجموعة التجريبيه يِ التطبيق القبلي والبعدي للإختبار المهاري (ن = 10 المجوعة التجريات )

\begin{tabular}{|c|c|c|c|c|c|c|c|c|}
\hline اللالاله & $\begin{array}{c}\text { Wilcox } \\
\mathrm{W}\end{array}$ & مستوى الدلالة & قيمة ت & درجـات الحريــة & 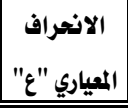 & الحسابي "م" التموسط & التطبيق & |الإختبار المهاري | \\
\hline \multirow{2}{*}{ 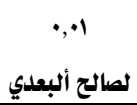 } & \multirow[t]{2}{*}{$r, \$ 10$} & \multirow{2}{*}{ 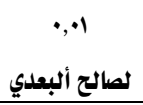 } & \multirow[t]{2}{*}{$17 V, \wedge 7$} & \multirow[t]{2}{*}{$1 \xi$} & $r, \Delta \varepsilon$ & $0, r V$ & قبلي & \multirow[t]{2}{*}{ المحور الأول } \\
\hline & & & & & $r, 1 \cdot \xi$ & $1 . \xi, \mathrm{VN}$ & بعدي & \\
\hline \multirow{2}{*}{ لصالح ألبعدي } & \multirow[t]{2}{*}{ r, \&ro } & \multirow{2}{*}{ لصالح ألبعدي } & \multirow[t]{2}{*}{$9 \Lambda, \wedge \Lambda$} & \multirow[t]{2}{*}{$\mathfrak{k}$} & $r, r A$ & 1,94 & قبلي & \multirow[t]{2}{*}{ المحور الثاني } \\
\hline & & & & & $r, q \vee$ & $1 \cdot A,\{7$ & بعدي & \\
\hline \multirow{2}{*}{ لصالج ألبعدي } & \multirow[t]{2}{*}{$r, \xi 11$} & \multirow{2}{*}{ 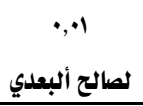 } & \multirow[t]{2}{*}{ Irv, 99r } & \multirow[t]{2}{*}{$\mathfrak{k}$} & $\xi, \bullet r$ & $r, r$ & قبلي & \multirow{2}{*}{ كجموع الإختبار } \\
\hline & & & & & $0,1 r$ & rit, 19 & بعدي & \\
\hline
\end{tabular}

يتضح من الجدول ( 11 ) ) ان قيم (ت) لكل محور من محاور الإختبار المهارى والدرجة الكلية

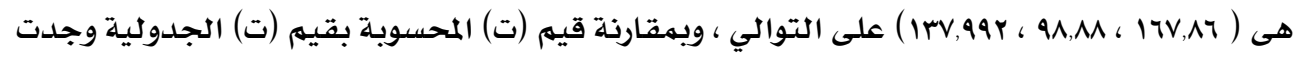

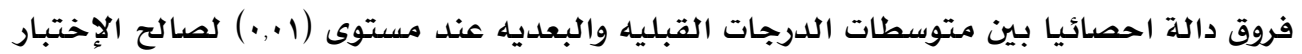

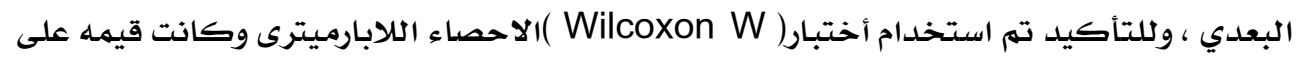

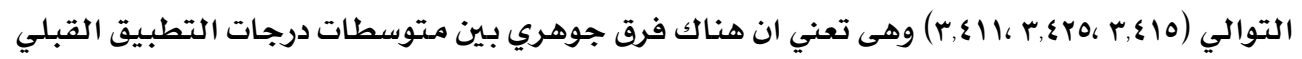

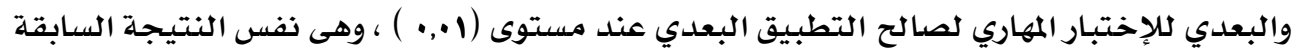

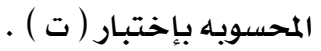

يمكن إرجاع النتيجهـ السابقه إلي طبيعه البيئه الإلكترونيه والتي تتيح الفرصده لكل طالبه

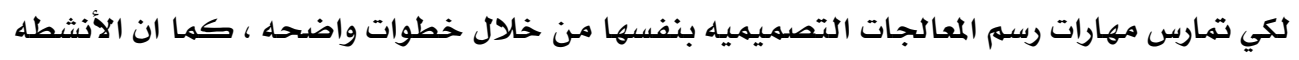


التى تندرج تحت البيئه التعليميه الإلكترونيه تعمل على زيادة تفاعل الطالبات مـع بعضهن البعض البهل

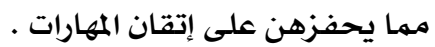

يتفق هذا مع دراسة كل من ( Kilic \& Turel : 2001 ) والتي كشفت نتائجها عن

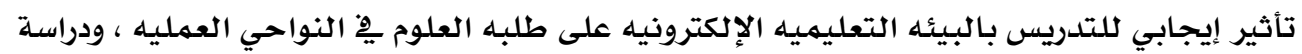
(Hung \&others : 2004)

$$
\text { الطلاب مهارات استخدام التصوير الرقهي . }
$$

كما تتفق النتيجه السابقه مـع نتائج دراسات كل من (لمياء محمود محمد القاضى ،

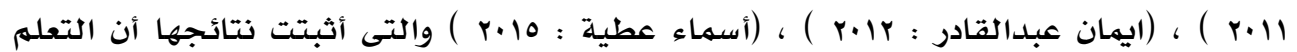

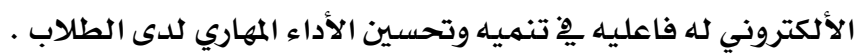

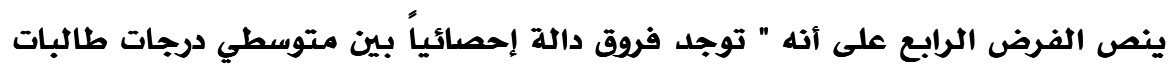

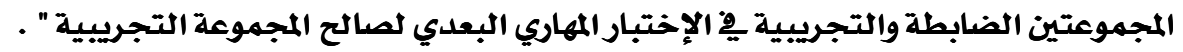

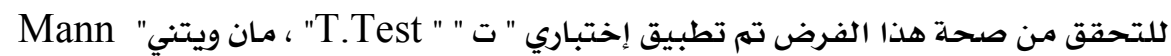
Whitney

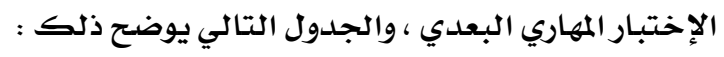
جدول (ir)

دلالة الفروق بين متوسطي درجات الطالبات بالمجموعتين الضابطه و التجريبيه

ـو التطبيق البعدي لإختبار المهاري

\begin{tabular}{|c|c|c|c|c|c|c|c|c|c|}
\hline الدلالة & $\begin{array}{c}\text { Mann } \\
\text { Whitney }\end{array}$ & مستوى الدلالة & قيمة ت & 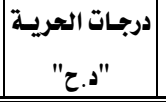 & الانحراف المياري "ع" & 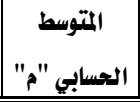 & $\begin{array}{l}\text { العدد } \\
\text { (j) } \\
\end{array}$ & المجموعات & الإختبار المهاري \\
\hline \multirow{2}{*}{ |التجريبية } & \multirow[t]{2}{*}{ צוצוצ } & \multirow{2}{*}{ الترالت لصالح } & \multirow{2}{*}{$7,7 v \gamma$} & \multirow{2}{*}{ ro } & $1 \cdot, r \cdot r$ & $\wedge \varepsilon, 17\rceil$ & ir & بعلى ضابطله & \multirow{2}{*}{ المحور الأول } \\
\hline & & & & & $r, 1 \cdot \varepsilon$ & $1 \cdot \xi, V \Psi$ & 10 & بعدى تجريبيه & \\
\hline \multirow{2}{*}{ |التجريبيه } & \multirow[t]{2}{*}{$\varepsilon$, rAr } & \multirow{2}{*}{ التجريبيه } & \multirow[b]{2}{*}{$1 \cdot, \Lambda \cdot \varepsilon$} & \multirow[b]{2}{*}{ ro } & $0, \cdot r$ & $19, r_{0}$ & ir & بعدى ضابطله & \multirow{2}{*}{ المحور الثاني } \\
\hline & & & & & r,qv & $1 \cdot 1,\{7$ & 10 & بعدى تجريبيه & \\
\hline \multirow{2}{*}{ الترال• لصالح } & \multirow[t]{2}{*}{$\xi, r 9 q$} & \multirow{2}{*}{ الترالت لصالح } & \multirow{2}{*}{ II, YYY } & \multirow{2}{*}{ ro } & $1 \cdot, A r$ & $\mid V r, \& r$ & ir & بعدى ضابطه & \multirow{2}{*}{ المجموع } \\
\hline & & & & & $0,1 r$ & $r 1 \%, 19$ & 10 & بعدى تجريبيه & \\
\hline
\end{tabular}

يتضح من الجدول (r r) ان قيم (ت) لكل محور من محاور الإختبار المهارى والدرجـة الكلية

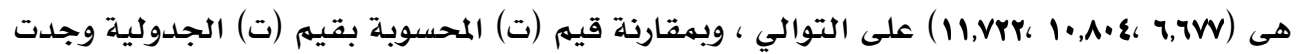

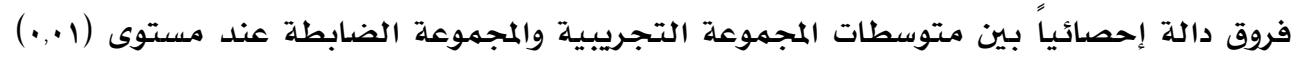

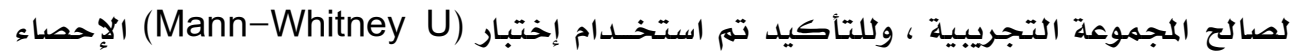

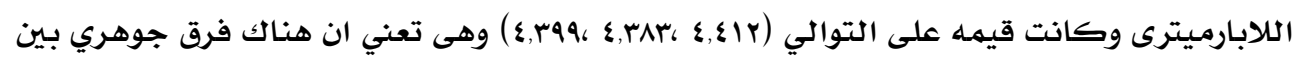




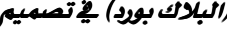
متوسطي درجات المجموعتين لصالح المجموعه التجريبيـه عند مستوى (1., •) ، وهى نفس النتيـة السبابقة.

يم-كن تفسير النتيجـه السـابقه إلي تقديه المحتوى العملي للهـجموعه التجريبيه فِ صورة التعليهم المبرمـج طريقة للتعلهم الذاتي والتي تقسهم فيها المادة الدراسية بطريقة منطقية إلى خطوات صغيرة منتظمهة يخ تتابع من خلال كتابة الأطر تبعاً لتسلسل عرض المحتوى لموضوع (رسهم معالجات

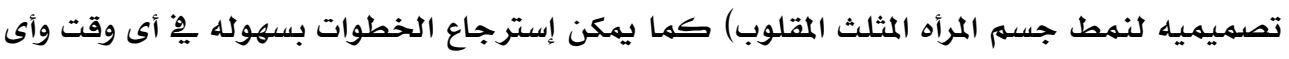
مكان ، عكس طريقة البيان العملي التي تشرح داخل الفصل مـرة واحدة فقط ، كما يمكن إرجاع

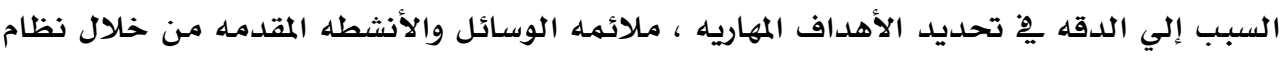

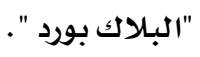

تتفق هذة النتيـجه مـع نتائج دراسـات كل من ( Asan\&Haliloglu:2005 ) ، ( محمد

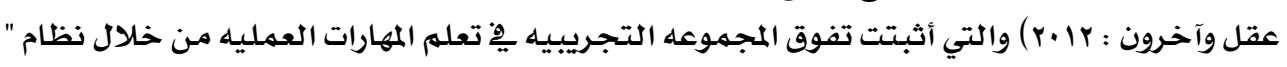
البـلاك بورد " على المجموعه الضابطه التي درست بالطريقه التقليديـه . قد يرجع السبب إلي ما ذكره ( Garrison , R \& Kanuka , H : 2004 ) ان من أهم

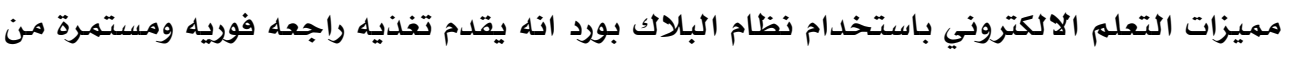
خلالها تستطيع الطالبات معرفه مستوياتهن المهاريه ، كما انه يسـاعد الطالبـات يخ الإلتزام بانجاز التكليفات والأنشطه يخ وقتها المحلدد ، و يشجع على التعلهم النشط الفعال من خلال تقديم أنشطه فرديه أو جماعيـه

ينص الفرض السادس على: (إيجابية رضا الطالبات نحو استخدام نظام التعلم الأكتروني

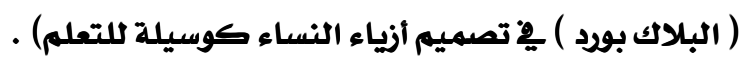

للتحقق من صححه هذا الفرض تم حساب المتوسطات الحسابية والإنحرافات المعيارية

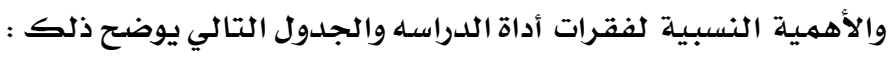




$$
\text { جدول (ir) }
$$

المتوسطات الحسابية والإنحرافات المعيارية والأهمية النسبية لفقرات أداة الدراسة لقياس رضا الطالبات

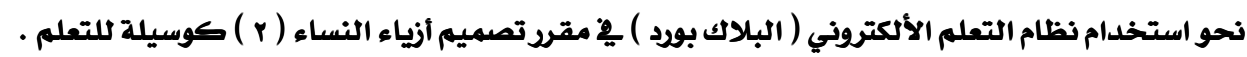

\begin{tabular}{|c|c|c|c|c|}
\hline |الأهمية & 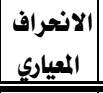 & | الموسط & 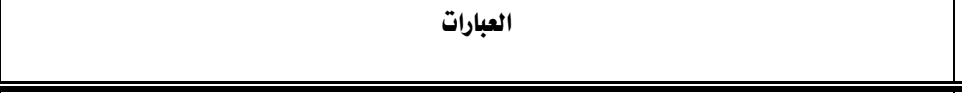 & 今 \\
\hline ar & $\cdot, \S 9$ & $\xi, \vee$ & أشعر بان نظام البلاك بورد نقلني من مرحله التلقي فقط إلى مرحلة المشاركه والمبادره في العمليه التعليميه & 1 \\
\hline ar & $\cdot, 01$ & $\xi, \uparrow$ & |أرى ان نظام البلاك بورد ساعدني في التواصل الفردي مع أستاذة المقرر والطالبات . & $r$ \\
\hline $9 \cdot, 7$ & $\cdot$ or & $\xi, 0$ & | ادرك اهمية مواعيد التواصل غير المتزامن الذى يوفرة البلاك بورد. . & $r$ \\
\hline ar & $\cdot 01$ & $\xi, \uparrow$ & | أتابع بشفف المنتديات المتوفره في البلاك بورد . . & $\varepsilon$ \\
\hline 91 & $\cdot, r q$ & $\xi, 9$ & |أشعر ان نظام البلاك بورد يسهم في تطوير عمليه التدريس . & 0 \\
\hline $9 \cdot, 7$ & •, ๆ乏 & $\{, 0$ & | أفضل تقديم الواجبات عن طريق البلاك بورد. . & 1 \\
\hline $1 \ldots$ & $\cdot, \cdot$ & 0 & | اشعر بالتحمس أثناء تلقي الدرس من خلال الفصل الافتراضي بالبلاك بورد. . & $\checkmark$ \\
\hline 94 & $\cdot, \pi$ & $\xi, \uparrow$ & | استخلام نظام البلاك بورد يجعلني محور العمليه التعليميه . . & $\wedge$ \\
\hline $9 \Lambda, 7$ & $\cdot, \mathrm{rq}$ & $\xi, q$ & | اتعلم ذاتياً من خلال نظام البلاك بورد . & 9 \\
\hline $9 \cdot, 7$ & $\cdot, \mathrm{V} \varepsilon$ & $\xi, 0$ & | أشعر بسهولة التواصل مع أستاذة المقرر من خلال نظام البلاك بورد . & $1 \cdot$ \\
\hline ar & $\cdot, \S 9$ & $\xi, 7$ & | أصبحت أحصل على معلومات أكثر من خلال نظام البلاك بورد . . & 11 \\
\hline ar & •, ro & $\xi, \Lambda$ & |أرى ان نظام البلاك بورد يقلل من دور المعلم في الفصول التقليديه & ir \\
\hline 1... & $\cdot, \cdot$ & 0 & |أتحمس لاستخدام نظام البلاك بورد في التعلم لانه لا يلزمني بمكان محدد أو وقت محلد . . & ir \\
\hline $9 \cdot, 7$ & $\cdot, \mathrm{v}$ & $\mathfrak{\xi}, 0$ & |أشعر ان الأنشطه التى تقدم من خلال البلاك بورد تتميز بالتنوع والافضليه عن الأنشطه المقدمه في الحجرات & $1 \varepsilon$ \\
\hline$\wedge \Lambda$ & $\cdot, \mathrm{rr}$ & $\mathfrak{\xi}, \mathfrak{\xi}$ & أجد صعوبة في إستخدام نظام البلاك بورد في تعلم تصمييم أزياء (؟) & 10 \\
\hline ar & $\cdot, \S 9$ & $\xi, \uparrow$ & |أشعر بتحسن مهاراتي أثناء تقلديم مقترحات تصميميه لمعالجه الأنفاط الجسميه بعد التعلم من خلال نظام & 17 \\
\hline ar & $\cdot, 01$ & $\xi, \uparrow$ & |أرى ان التعلم بنظام البلاك بورد ينمي قدراتي على التفكير العلمي في تصميي الأزياء . & iv \\
\hline $1 \ldots$ & $\cdot, \cdot$ & 0 & | اجد سهوله في الأطلاع على المعلومات الجديده لمقرر تصميم أزياء (r ) قبل شر حه من خلال نظام البلاك بورد . & in \\
\hline ^o & $\cdot, r$. & $\xi, r$ & |بسرعه وفاعليه . .بتام البلاك بورد يساعدني على انجاز مهارات رسم المعالجات التصميميه للأنماط الجسميه للمرأه & 19 \\
\hline 1... & $\cdot, \cdot$ & 0 & | اشعر بعدم تحسن مستواي المعرفي في مقرر تصميم أزياء (r) بعد التعلم بنظام البلاك بورد. & r. \\
\hline$\wedge \Lambda$ & $\cdot, \mathrm{AT}$ & $\xi, \xi$ & |أرى ان نظام البلاك بورد سيحل تدريجياً محل التعلم التقليدي. & r) \\
\hline ar & $\cdot$, ro & $\xi, \Lambda$ & |أحب الأتتحاق ببرامج دراسيه أخرى تعتمد على نظام البلاك بورد في التعلم. . . & rr \\
\hline 1... & $\cdot, \cdot$ & 0 & أرى ان التدريس بالطريقه المعتاده يسهم في حل كثير من المشكلات التي يعانى منها نظام البلاك بورد. & $r r$ \\
\hline ar & $\cdot$, ro & $\xi, \Lambda$ & | أفضل التعلم من خلال البلاك بورد لانه يساعدني على طرح الأفكار والآراء والاستفسارات دوذ خجل . & r६ \\
\hline $9 \cdot, 7$ & $\cdot, 1 \xi$ & $\xi, 0$ & |أشعر بالإستفادة من التفذيه الراجعه الموجهه لى من أستاذة المقرر عقب كل إختبار . & ro \\
\hline 19 & $\cdot, 1 \xi$ & $\mathfrak{\xi}, \uparrow$ & |شرحهي بشفف لتعلم المزيلد عن إمكانيات نظام البلاك بورد ـ بار ـالمقرر عقلراجعه الموجهه ط الجسميه للمرأه ه بل & ry \\
\hline ar & $\cdot, \S 9$ & $\xi, \uparrow$ & أرى ان استخدام نظام البلاك بورد في تلقي المقررات الدراسيه يعمل على تبسيطها ويجعلها أكثر وضوحاً. & $r v$ \\
\hline 9 १ะ १ & $\cdot, \S 7$ & $\xi, \curlyvee$ & |أشعر بان التدريس غبر نظام البلاك بورد يؤدى إلى ضعف الترابط الإجتماعي بين الطالبات . . . & rA \\
\hline $1 .$. & $\cdot, \cdot$ & 0 & | أتحمس بشده للمحاضرات الصوتيه لمقرر تصميه أزياء (؟ ) من خلال نظام البلاك بورد. . & rq \\
\hline $9 \xi, 7$ & $\cdot, \$ 7$ & $\xi, \vee$ & | أشعر بالملل من خلال دراسه مقرر تصمييم أزياء (r ) باستخدام نظام البلاك بورد . . & r. \\
\hline $9 \xi$ & •, §r & $\xi, \vee$ & المجهوع & ri \\
\hline
\end{tabular}


يتضح من الجدول ( سا ) إيجابية رضا الطالبات بنسبه ( §q ٪ ) نحو استخدام نظام التعلم

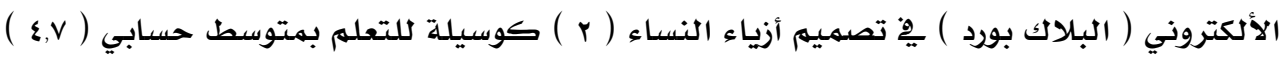

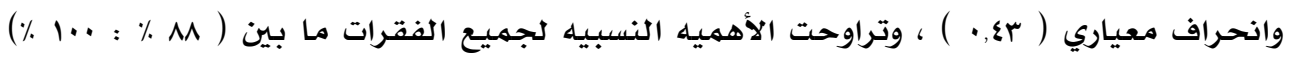

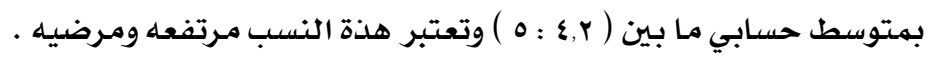

يمكن تفسيرإرتفاع نسبة رضا الطالبات تجاه التعله " بنظام البلاك بورد" إلى توفر قدر

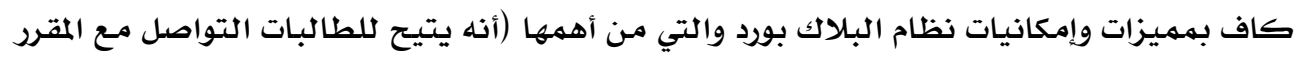

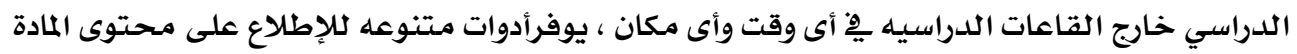

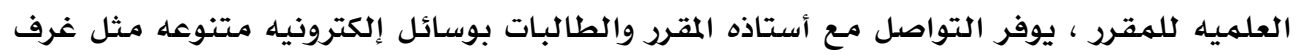

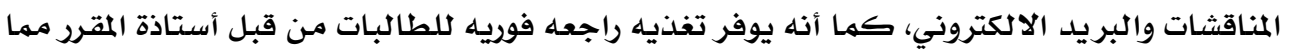

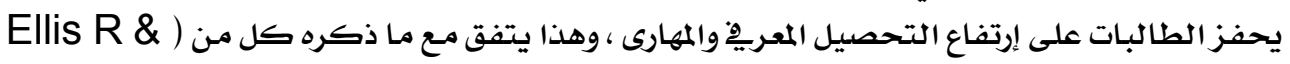

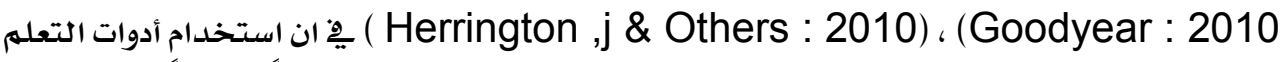

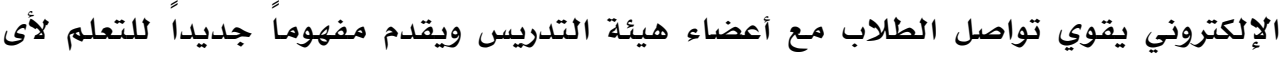

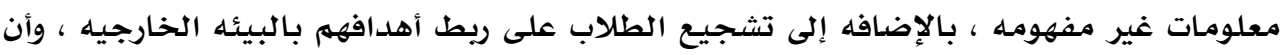

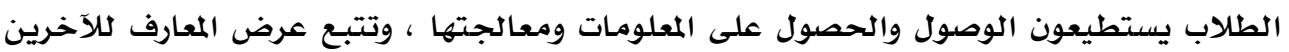

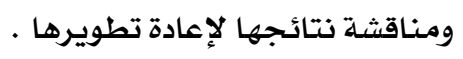

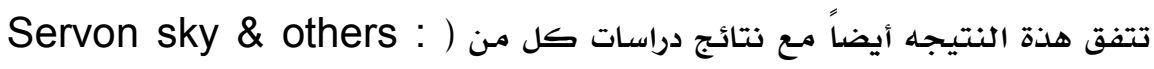

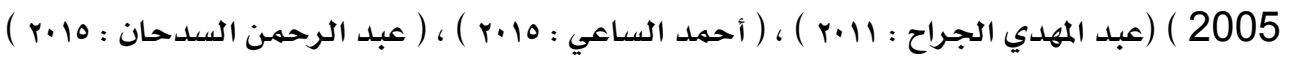

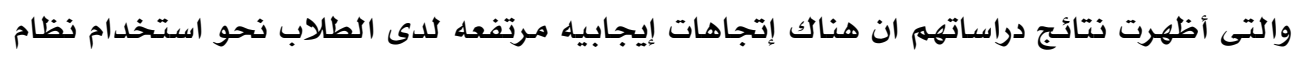

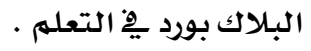

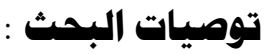

مِّْو ضوء النتائج التي أسفر عنها البحث الحالي يمكن تقديهم التوصيات التالية :

ا ـ تطبيق الموقع الإلكتروني على طالبات تخصص تصميم الأزياء جميعهن لما أثبته مـن فاعليـة فِيْ

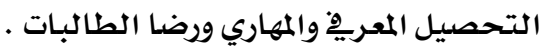

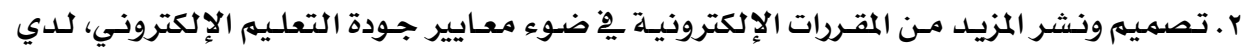
طلاب كليات الاقتصاد المنزبي.

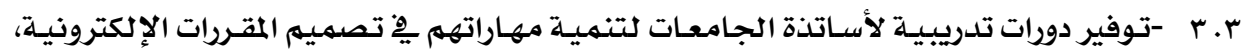

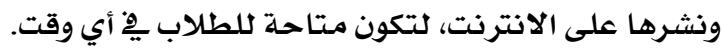

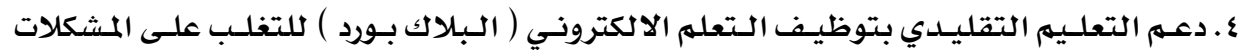

ه .تطبيق أساليب التعلهم من خلال بيئات التعلهم الإفتر اضيه يِّ الجامعات وِِّ جميع المقررات .

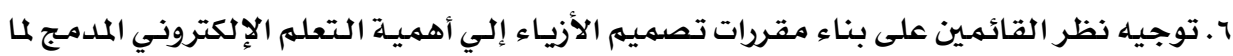
له من فاعليه يف التدريس. 


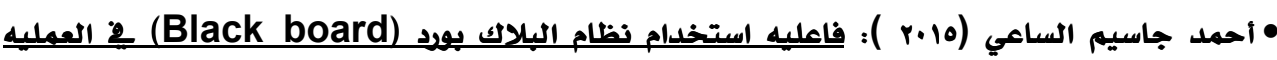

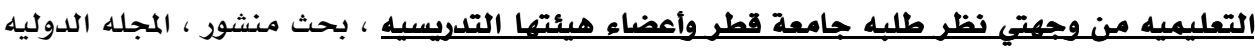

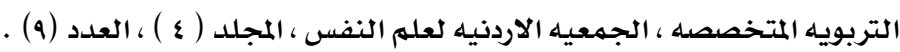

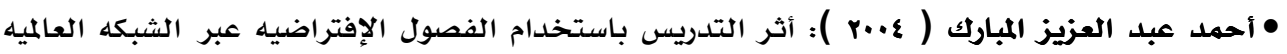

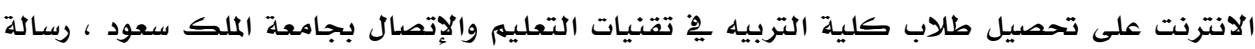

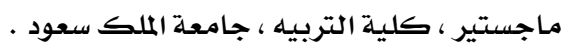

• أحمد عطا الله ( 1999 ) : الأسس التشريحية للحسم البشري، الهيئة المصرية العامة للكتب ،القاهرة .

$$
\text { • أحمد مفتي (199V ) : التشريح للفنانين ، دار دمشق للنشر والتوزيع ، سوريا. }
$$

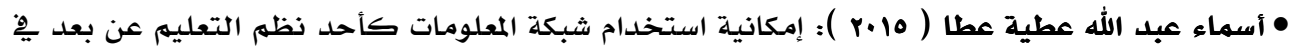

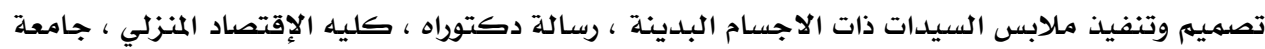

$$
\text { المنوفيه . تصنيم }
$$

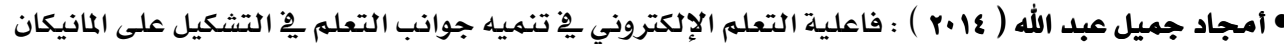

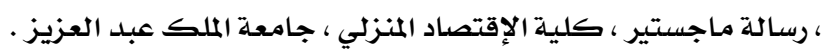

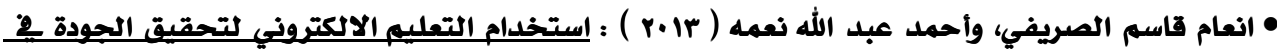

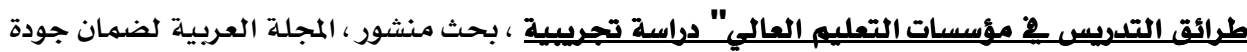

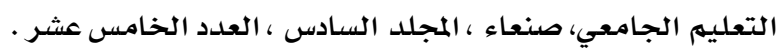

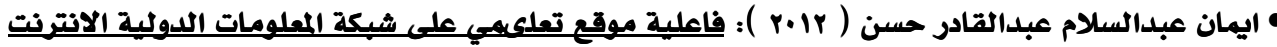

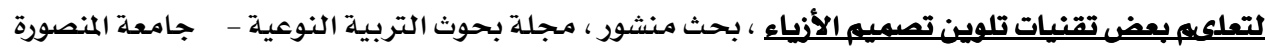

$$
\text { ، العدد الخامس والعشرون . }
$$

• إيهاب فاضل أبو موسى (v. . r) : تصميم الأزياء وتطورها ( مفهومه ، تطوره ، ملحقاته ، أسالييه التطبيقيه )

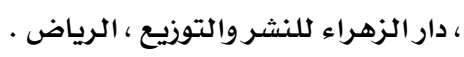

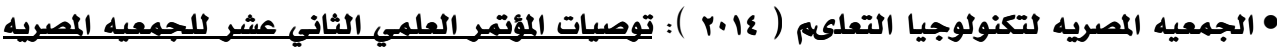

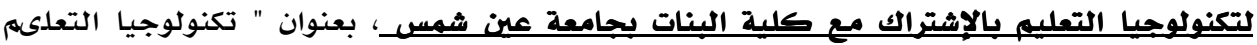

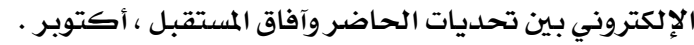

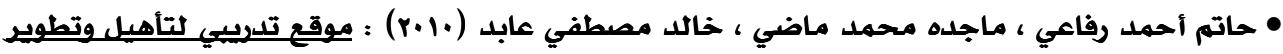

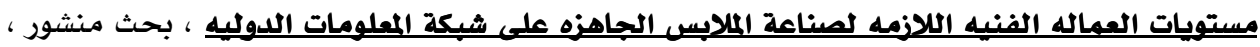

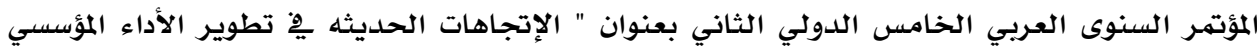

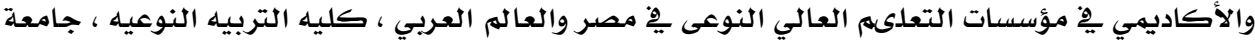


• حمدي إسماعيل شعبان ( r. . م) : فاعلىة موقع لتعلىم مقر تكنولوجيا التعليم عن بعد على تحصيل وأداء طالبات كلية التربيه بعبري وإتجاهتهن نحو هذا الموقع ، بحث منشور ، مجله دراسات وبحوث تكنولوجيا

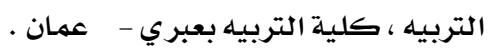

• دلال إستيتيه ، عمر سرحان ( r..v ) : تكنولوجيا التعليم والتعلمروالتعليم الإكتروني، دار وائل للنشر ، عمان

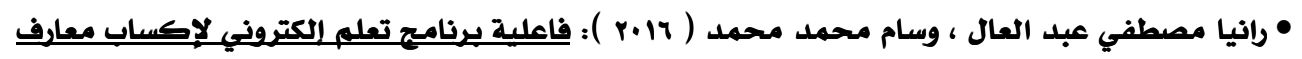
ومهارات بناء وتصميم نماذج ملابس الأطفال، بحث منشور ، مجله التصميه الدوليه ، كليه ، محيه الفنون

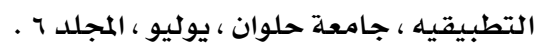

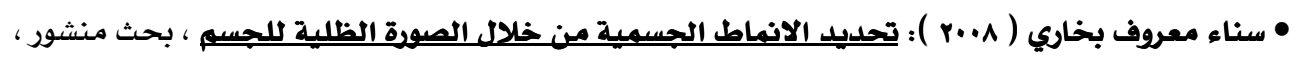
مجلة علوم وفنون ، بجامعة حلوان، المجلد العشرون ، العدد الثاني ( ابريل ) ) .

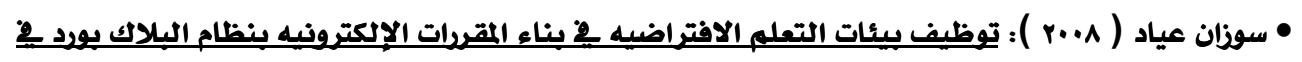

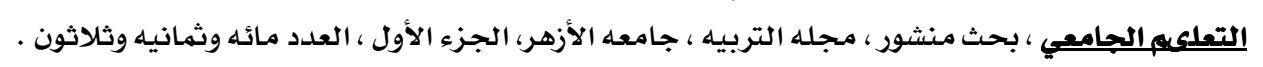

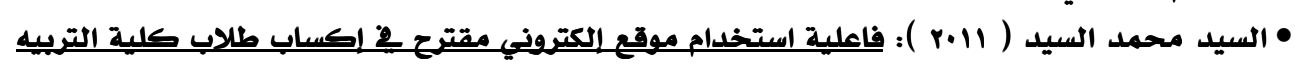

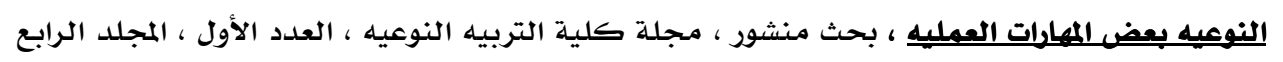
عشر.

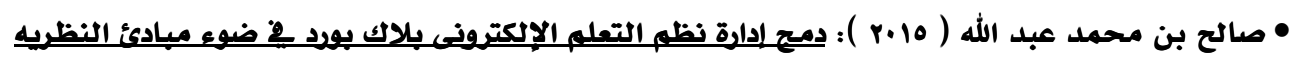

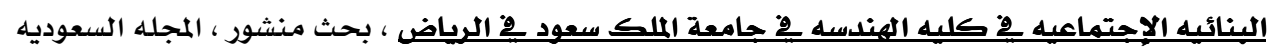

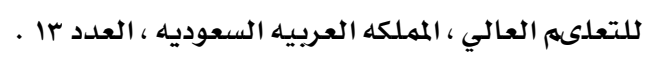

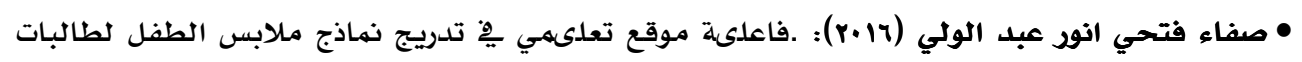

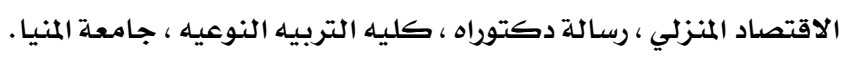

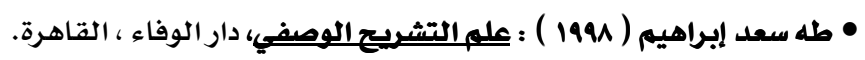

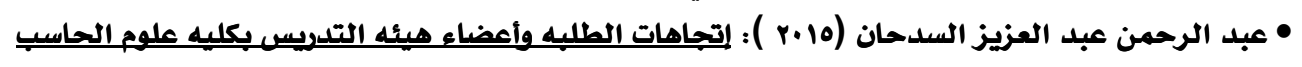

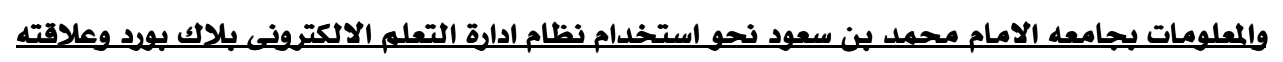
يبعض المتفيرات ، بحث منشور ، مجلة العلوم التربويه ، جامعه الامام محمد بن سعود الاسلاميه ، العدد العادي • الثاني

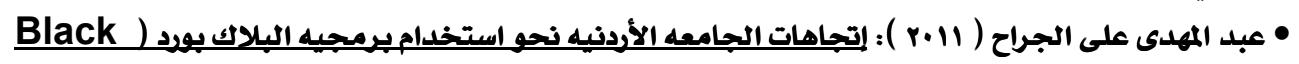

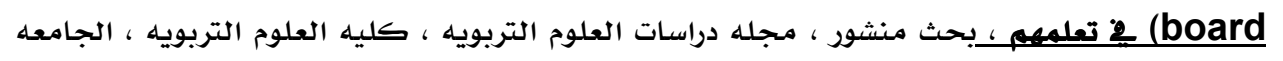

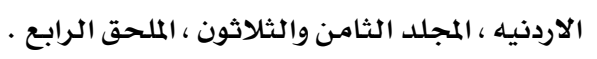

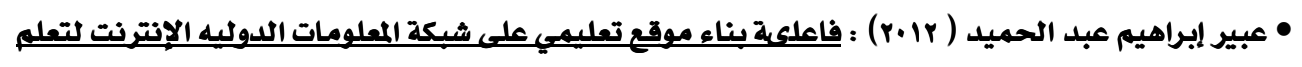
الأساليب التقنيه لتشغيل الجلود الطبيعيه ، بحث منشور ، مجلة كلية التربيه النوعيه ، جامعة المنصوره ،

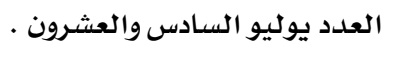

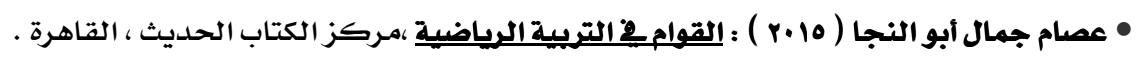




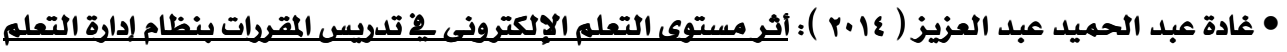
(Black board)

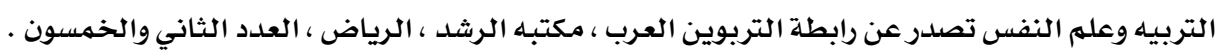

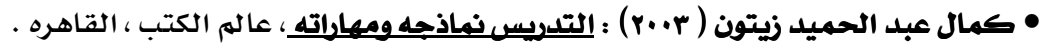

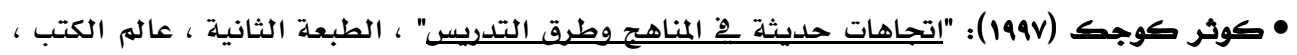
القاهرة.

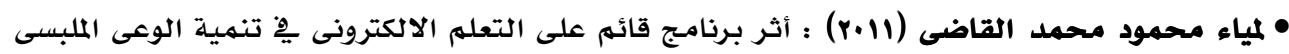

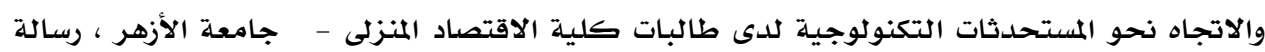

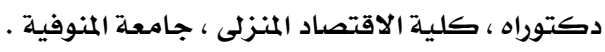
• مجدي سعيد عقل ، محمد عطيه خميس ، محمد سليمان أبو شقير ( r r r ) ) تصمييم بيئه تعليمييه

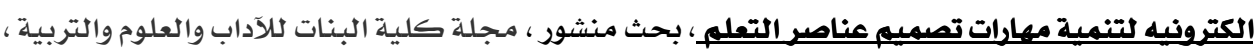
جامعه عين شمس ، العدد الثالث عشر ، يناير.

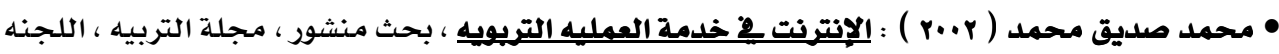

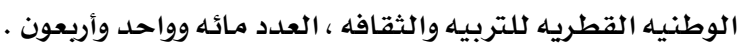

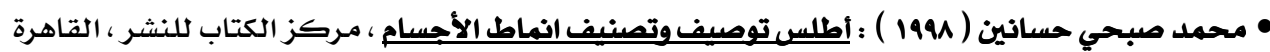

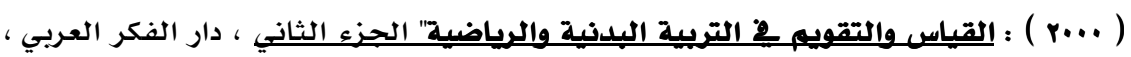
القاهرة • محمد محمد إبراهيم ( 1991 ) : تشريح الجسم البشري ، المكتبة الأكاديمية ، القاهره .

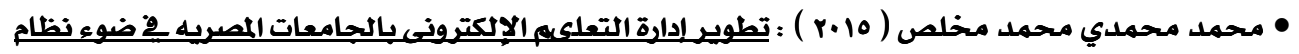

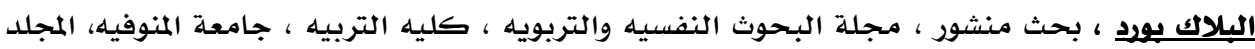

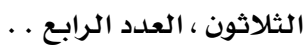

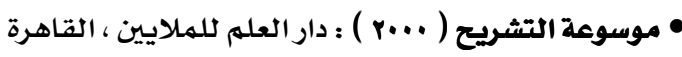

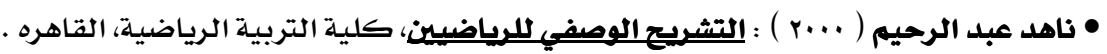

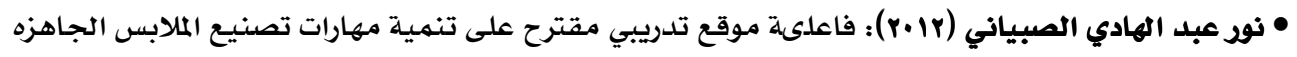

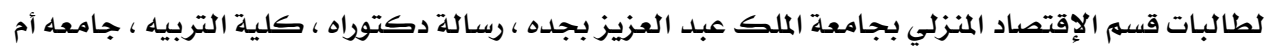
القرى .

• هدى سلطان التركي ( r.r ) ) : إستحداث نموذج قياس خاص بقوام السيدة السعودية " ،بحث منثور -

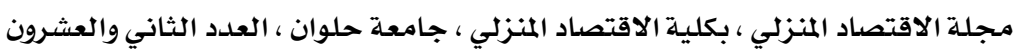

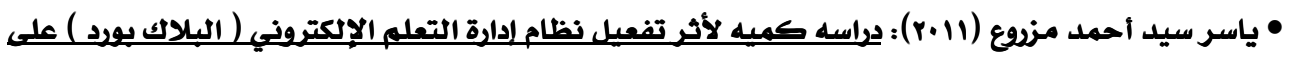

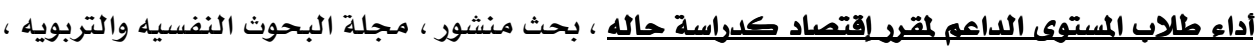

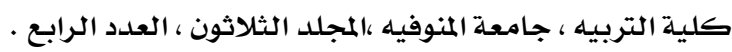

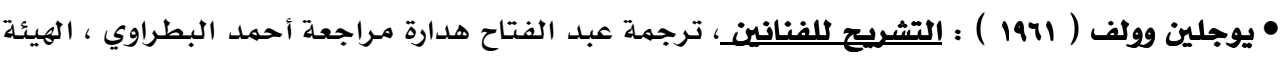
المصرية العامة للكتاب ، القاهرة . لمولفين 


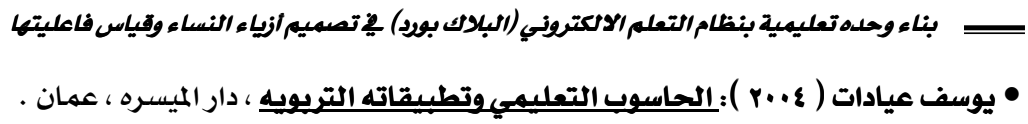

- Akkoyunlu, B\& Soylu, and M: (2016): A study on Students' Views on Blended Learning Environment. TOJDE, the Turkish online Journal of Distance Education, Anadolu University, VOL. 6488, NO.7.

- Asan , A ., Haliloglu , Z., ( 2005) : Implementing project based learning in computer classroom, The Turkish online Journal of Educational Technology, Volume( 4), Issue(3),

- Balci , M \& Soran , H : (2007) : Students' Opinione on Blended Learning TOJDE, the Turkish online Journal of Distance Education, Anadolu University g VOL . 6488, NO . 10.

- Clarke, A: (2004 ): E Learning Skills , plagrave Macmilian, New Yourk .

- Ellen (1981) : The Complete Bonnie Augusts Dress Thin System, Rawson Wade Pulishers, inc. NewYork

- Ellis, R., \& Goodyear, P. (2010) : Students' experiences of e-learning in higher education the technology of sustainable innovation. New York, NY: Routledge.

- Faerm Steven ( 2010) : FASHION Design Course " principles, practice, and techniques : the practical quide for aspiring fashion designers, Modern Age Repro House, LTD, HONG Kong .

- Garrison, D \&Vaughan, N. (2007): Blended learning in higher education. From: work /principles and guide line

- Graham , C \& Bonk , J ( 2005 ) : Hand book of Blended Learning “ Global perspectives, local Designs, co Pfeiffer publishing, san Francisco .

- HAGEN KATHRYN :( 2011): FASHION ILLUSTRATION for Designers, Pearson education, Inc, publishing as prentice Hall, Upper Saddle River, New Jersey.

- Heirdsfield 'A \&Walker ‘S \& Tambyah, M, \& Beutel,D. (2011): Blackboard as an online learning environment: what do teacher education students and staff think, Australian Journal of Teacher Education ، ECU University, 36(7) ‘1-17.

- Herrington, J \& Reeves, T., \& Oliver, R. (2010): A guide to authentic elearning. New York, NY: Routledge. 
- Hung Vincent H.K\& Keppell Mike and Jong Morris S.Y. (2004): Using Project based learning to enhance meaningful learning through digital video production. Retrieved in (1- 12 - 2016) from http://www.ascilite.org/conferences/perth04/procs/hung.html

- Katherine Blair :( 2000) : "Evaluation of Web - based Instruction in interior design education : a pilot study, Michigan University - MA California

- Kilic , Y \& Turel , M ( 2001) : A Comprehensive Evaluation of Learning Objects - Enriched Instructional Environments in Science Classes, Contemporary Educational Technology, Faculty of Communication Sciences, Anadolu University Volume( 2), Issue(4), Turkey

- Martin, F (2008) Black board as the Learning Mangement System of a computer Literacy, MERLOT, Journal of Online learning and teaching.

- Martin J , Weller : (2000 ): The Use Of Narrative To provide A cohesive Structure For Web Based Computing Course, Journal Of Interactive Media In Education, No 1, August .

- Mbonu Ezinma (2014): FASHION Design Research, Laurence King Publishing, LTD, LONDON, United KINGdom.

- Morisse, K \& Romm, M\& Schuler, T \& Wichellaus, S (2009). $\underline{\text { A Mobile }}$ Blended Learning Approach based on pod casts with respect to the students' media literacy. Conference: Mobile, Hybrid, and On-line Learning, 41-46.

- Organization For Economic Co - operation and Development (2005): Elearning in tertiary education, Paris, France: OECD

- Sangeeta K.,\&L. Monohar\&S. Shikhar ( 2011 ) : Elearning as a Research Area: An Analytical Approach", International Journal of AdvancedComputer Science and Applications, Vol. 2, No. 9

- Servonsky, J\& Daniels, L\& Davis, B: (2005): Evaluation of Blackboards as a Platform for Distance Education Delivery, the ABNF Journal, Black Nursing faculty, Chicago, November/December.

- Spillane, Mary (1994): The Complete Style Guide, Color Me Beautiful Organisation, LTD London. 
בب بناء وحلد تعليمية بنظام التعلم الاكتروني (البلاك بورد) في تصميم/زياء النساء وقياس فاعليتها

- Wolf MARY (2006): Fashion, The good heart Wilcox company, Inc., West Chester, Pennsylvania

- www.Black board .com

- http://www.goodreads.com/topic/show/1427653-body-types-shapes-menand-women

- http://www.emeraldinsight.com/reprints 


\title{
Building an Educational Unit of the Electronic Learning (Blackboard) in Designing Women's Fashion and Measuring Its Effectiveness
}

\author{
Dr / Sahar Ali Zaghloul Ali
}

\section{Abstract}

This current research aims at building an educational unit of the electronic learning (blackboard) in designing women's fashion according to the scientific steps and educational basics to test its effectiveness in developing the knowledge and skills of the sixth level students at the Department of Fashion Design, Faculty of Design and Home Economics, Qassim University and determining the degree of female students' satisfaction regarding the use of Blackboard system as a means of learning.

\section{This current research has been limited to the following:}

- Time limits: Second semester of the academic year (2015 / 2016 G).

- Spatial limits: Department of Fashion Design, Faculty of Design and Home Economics, Qassim University.

- Human limits: 27 female students of the sixth level at the Department of Fashion Design.

- Educational limits:

1. A unit from the fashion design curriculum (Unit 2) that is taught to the female students of the sixth level at the Department of Fashion Design. The said unit comprises the following subjects (anatomy of women's body - the historical development of women's bodies patterns - modern classification of women's bodies patterns - processing the design of triangle body pattern). The selection of such pattern was due to its being the most common pattern in the Kingdom of Saudi Arabia with the aim to relate the educational process to the practical realty

2. The educational system (Blackboard) used at Faculty of Design and Home Economics, Quasim University.

3. The integrated electronic learning level: This level combines class learning and learning through technology providing that the teacher shall be the facilitator and the director of the educational situation not the prompter. Bearing in mind that the role of the teacher is the cornerstone due to the positive role he plays in the learning process.

(Huda Al-Turki, 2006 G) and (Sanaa Maarouf, 2008 G).

\section{Research Methodology:}

- The descriptive methodology: Through applying the questionnaire to identify the degree of the female students' acceptance of the electronic learning management system use (Blackboard) in the Fashion Design curriculum 2 and their reaction with it.

Assistant professor at the Department of Clothes and Textile - Faculty of Home Economics - Helwan University 
- Quasi-experimental methodology: Through building a unit from the fashion design curriculum(2) according to the system of electronic learning ( Blackboard) and its application on the experimental students group and comparing their results with those of the control group to measure the effectiveness of the unit.

\section{Variants of the research:}

- Independent variants: The educational electronic website of Blackboard learning system of the unit of the fashion design curriculum (2).

- Dependent variants: (cognitive domains and skills domains related to the suggested unit - the degree of the female students' acceptance of the electronic learning management system use (Blackboard).

Sample of the research: The sample of the research comprised 27 female students of the sixth level (Grade Three) at the Department of Fashion Design, Faculty of Design and Home Economics, Qassim University. They were divided into two groups, as follows:

1- The control group: This group studies processing body patterns from the design perspective according to the conventional learning system (practical explanation).This group comprised 12 female students.

2. The experimental group: This group studies processing body patterns from the design perspective through the educational electronic website of Blackboard learning system. This group comprised 15 female students following excluding the students repeating this year due to their failure last year.

\section{The research concluded the following results:}

1. The attainment level of the experimental group students reaches the limit of effectiveness according to their marks in the cognitive attainment test and the skills test. The attainment levels of the experimental group in the cognitive attainment test and the skills test were (1.96) and (1.96) respectively. Such values are located in the range defined by Black at (1.2:2) which indicates the effectiveness of the electronic educational system (Blackboard) in learning women's fashion design.

2. There are differences of statistical differences, at 0.01 function level, between the marks averages of the experimental group students at the prior and post application of the attainment test, in favor of the post application test.

3. There are differences of statistical differences, at 0.01 function level, between the marks averages of the experimental group and control group at the prior and post application of the attainment test, in favor of the experimental group.

4. There are differences of statistical differences, at 0.01 function level, between the marks averages of the experimental group students at the prior and post application of the skills test, in favor of the post application test.

5. There are differences of statistical differences, at 0.01 function level, between the marks averages of the experimental group and control group at the post application of the skills test, in favor of the experimental group.

6. Positivity of female students' satisfaction at $94 \%$ regarding the use of the system of electronic learning ( Blackboard) in designing women's fashion (2)as a means of learning at the mean of 4.7 and a standard deviation of 0.43 . The relative importance of all phrases ranged between $88 \%$ and $100 \%$ at the mean of $(4.2: 5)$. 